Portland State University

PDXScholar

7-6-1993

\title{
Anti-Bolshevism and the Advent of Mussolini and Hitler: Anglo-American Diplomatic Perceptions, 1922-1933
}

Lisa Kay Walker

Portland State University

Follow this and additional works at: https://pdxscholar.library.pdx.edu/open_access_etds

Part of the History Commons

Let us know how access to this document benefits you.

Recommended Citation

Walker, Lisa Kay, "Anti-Bolshevism and the Advent of Mussolini and Hitler: Anglo-American Diplomatic Perceptions, 1922-1933" (1993). Dissertations and Theses. Paper 4629.

https://doi.org/10.15760/etd.6513

This Thesis is brought to you for free and open access. It has been accepted for inclusion in Dissertations and Theses by an authorized administrator of PDXScholar. Please contact us if we can make this document more accessible: pdxscholar@pdx.edu. 
AN ABSTRACT OF THE THESIS OF Lisa Kay Walker for the Master of Arts in History presented July 6, 1993.

Title: Anti-Bolshevism and the Advent of Mussolini and Hitler: Anglo-American Diplomatic Perceptions, $1922-1933$

APPROVED BY THE MEMBERS OF THE THESIS COMHTTEE:

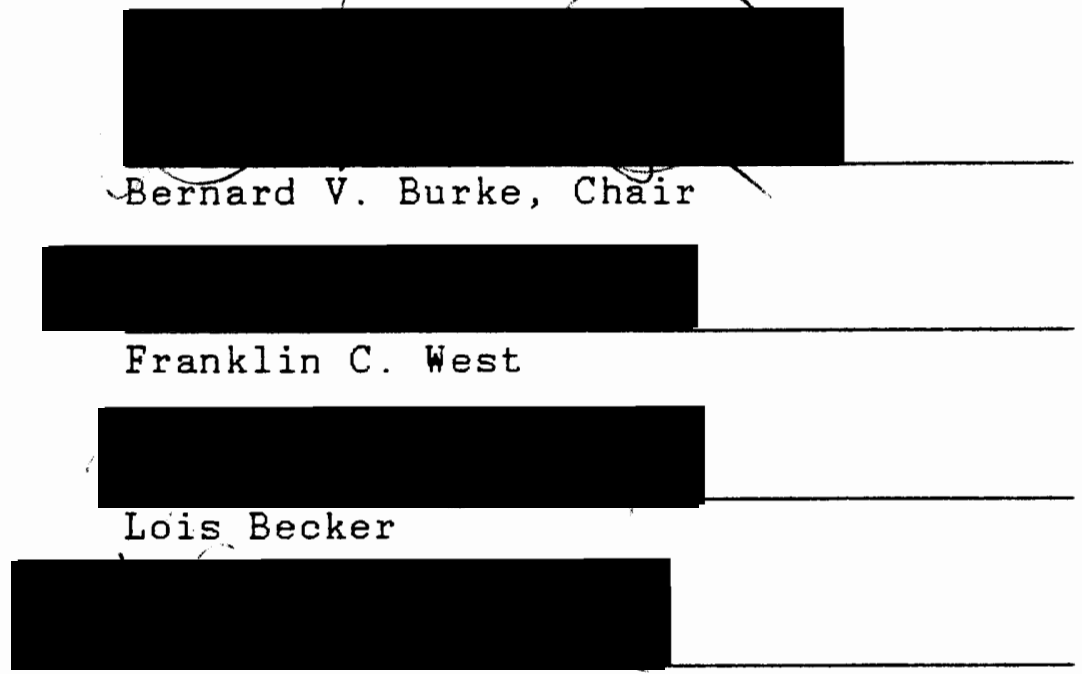

Louis Elteto

The history of World War II has led many Americans to view Benito Mussolini's Fascist Italy and Adolf Hitler's Nazi Germany as European variants of a single Fascist ideology. However, in the early years of the Mussolini and Hitler regimes, the conceptual category of international Fascism was by not so well-established, particularly where the Nazis were concerned. American and British diplomats stationed in Germany in the early 1930s only occasionally 
interpreted the rising Nazi party as an offshoot of Fascism, but frequently referred to it as a possible form of or precursor of Bolshevism in Germany. Published and unpublished American foreign policy documents, published British diplomatic documents, and a wide array of secondary sources have contributed information showing how perceptions of Nazism and Bolshevism were influenced by matters that clouded the issues. The similarity of American and British views on the subjects of Bolshevism, Fascism, and Nazism can be attributed to the new understanding among the policy elites of the two nations as they became the leading status que powers after World War I. The United States in particular had gone through tremendous organizational changes during and after the war, and was entering into a new era of professional and bureaucratized foreign policy that differed from its ad hoc diplomacy of the past.

American foreign policy of the interwar period combined a strong interest in business expansion with a relative lack of desire for international political entanglements. American political commitments of the 1920s, particliarly in Germany, were backed primarily by loans and investment, and through reparations revision plans designed by unofficial diplomats recruited from the private sector. As American financial commitments to Germany became more dependent on German repayment, and as 
the Depression tightened its grip, the rise of the Nazis became an ever greater source of alarm. This concern was related not only to their unclear and ill-defined political ideas, but to the threat they seemingly posed to financial stability - a threat that increased their resemblance to the Bolsheviks in the minds of many diplomatic observers.

Various other factors were important in developing the Anglo-American view of Nazism as related to Bolshevism. These included the almost obsessive intensity of antiBolshevism in the United States and Great Britain throughout the interwar period; the close association of Bolshevism with economic chaos in the minds of AngloAmerican leaders, with a concomitant tendency to see Bolshevism developing wherever economic chaos occurred in Europe; and the strong admiration for Mussolini's Italy in both Britain and the United States, which precluded possibilities of seeing much in common between Italian Fascism and Nazism during this period.

Some important sources of conceptual confusion were inherent in the policies of Germany's post-World war I Weimar Republic. Leading German diplomats and politicians of the republic, such as Gustav Stresemann, used AngloAmerican fears of Bolshevism as a cornerstone of their policy to gain revisions and modifications of the harsh terms of the Versailles Treaty. In the early 1930s, the "Bolshevism bogey" was used by Ambassador Frederic Sackett, 
a political appointee of Herbert Hoover, to get Hoover's attention so that he would modify reparations policy in favor of Sackett's friend, the embattled Chancellor Heinrich Brüning. The internal factions of the rising Nazi party, including the left-leaning wing led by Gregor Strasser, appeared to give some credence to the idea that the Nazis could harbor communistic elements.

After Hitler's rise to the chancellorship in 1933, American and British observers began to note more resemblances between the Hitler and Mussolini regimes. However, many of their earlier observations about the similarities of Nazism and Bolshevism have validity in terms of the more totalitarian nature of these regimes as compared to Italian Fascism and its other less extreme variants. 
ANTI-BOLSHEVISM AND THE ADVENT OF MUSSOLINI AND HITLER:

ANGLO-AMERICAN DIPLOMATIC PERCEPTIONS, 1922-1933

by

LISA KAY WALKER

A thesis submitted in partial fulfillment of the requirements for the degree of

MASTER OF ARTS

in

Portland State University

1993 
TO THE OFFICE OE GRADUATE STUDIES:

The members of the Committee approve the thesis of Lisa Kay Walker presented July 6, 1993.

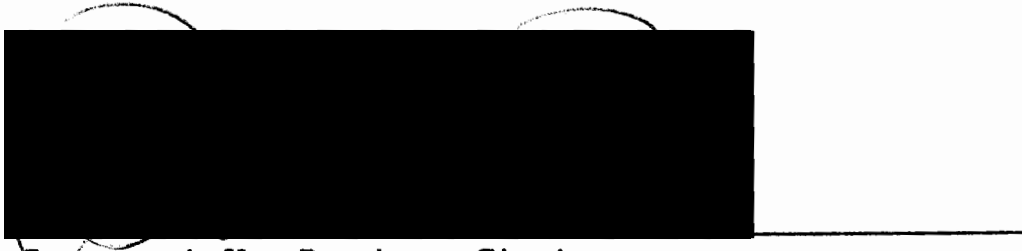

Bernard V. Burke, Chair

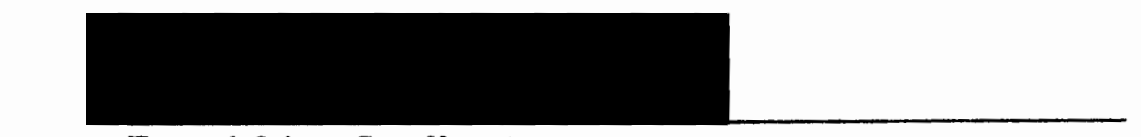

Franklin C. West

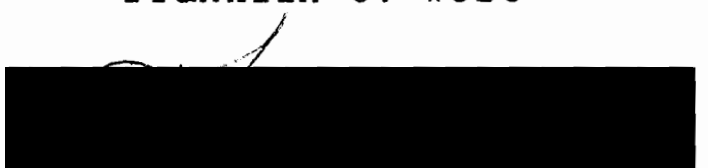

Lois Becker

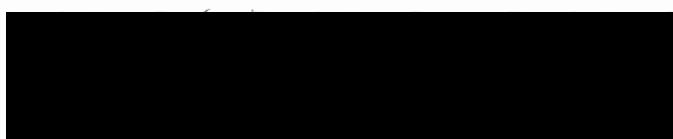

Louis Elteto

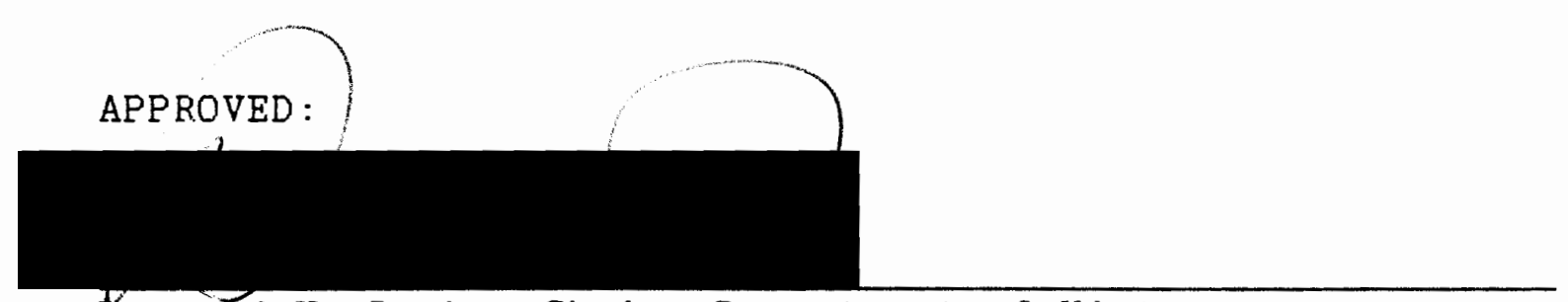

Bernard V. Burke, Chair, Department of History

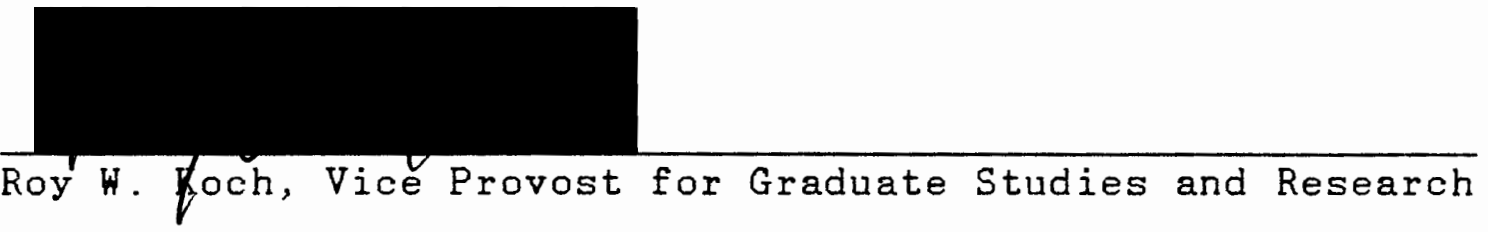




\section{ACKNOWLEDGEMENTS}

The long-delayed conclusion of this project offers me an opportunity to thank several people who made important contributions to its completion. I would like to take this opportunity to thank Professors Lois Becker, Louis Elteto, and Franklin West for serving on my thesis committee and for contributing many useful observations and challenging questions. Lee Ellington and Diane Gould of the History Department office deserve extra thanks for their patience and willingness to guide me through the sometimes confusing pathways of graduate school paperwork. Maureen Eldred and the Graduate Office staff were unfailingly helpful in answering my questions about style and format.

Marit Federcell deserves special thanks for her dedication to helping me overcome obstacles that were keeping me from completing this project. My co-workers at Oregon Council for the Humanities offered encouragement and understanding. My family, as always, was in my corner. However, my greatest debt of all is to Bernard V. Burke, my thesis advisor and committee chair, who never gave up on me and my work. As a teacher, scholar, employer, department head, and human being, he has set standards that his students, myself included, can only hope to emulate. 
TABLE OF CONTENTS

PAGE

ACKNOWLEDGEMENTS $\ldots \ldots \ldots \ldots \ldots \ldots \ldots \ldots \ldots \ldots \ldots \ldots \ldots \ldots \ldots \ldots$

CHAPTER

I INTRODUCTION $\ldots \ldots \ldots \ldots \ldots \ldots \ldots \ldots \ldots \ldots \ldots$

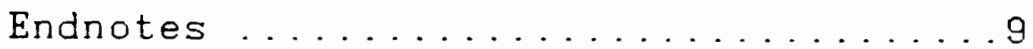

I I THE ANGLO-AMERICAN DIPLOMATIC BACKGROUND . . . 10

Endnotes .......................

II MUSSOLINI AND THE AMERICANS ...........44

Endnotes.................... 72

IV THE AMERICANS AND WEIMAR GERMANY --

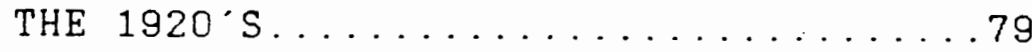

Endnotes ....................... 105

$\mathrm{V}$ THE AMERICAN DIPLOMATS AND THE WEIMAR

REPUBLIC, $1930-33 \ldots \ldots \ldots \ldots \ldots \ldots \ldots 110$

Endnotes.................... . . . 134

VI BOLSHEVISM, FASCISM AND NAZISM --

CONCLUSIONS ................. 140

Endnotes...................... 151

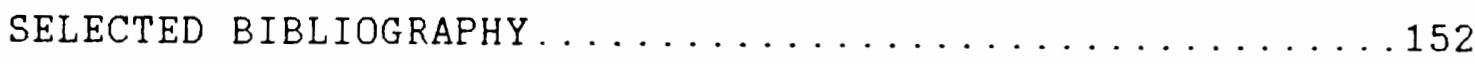




\section{CHAPTER I}

\section{INTRODUCTION}

During the years 1930 to 1933 the National Socialist German Workers Party, a new and alarming political phenomenon, rose rapidly to power amid the disintegration of the Weimar Republic. American diplomats in Germany reported regularly on the activities of the Nazis, but their views were constrained by their own prejudices and experience. When reporting on the disorderly, rabblerousing tactics of the Nazis before they came to power, American diplomats in Berlin frequently used the analogy of Russian Bolshevism. However, diplomats serving in Washington and those with previous experience in Italy could and often did see Nazism as being related to its most obvious ideological source, Italian Fascism.

The situation was somewhat different before and after the crucial period of 1930 to 1933. The reports of American military attaches in the early 1920 s had remarked on the similarities of the Nazi Party and Mussolini's recently ascended Fascists, and American diplomats frequently compared the two regimes after Hitler took over as Chancellor in January 1933. Yet during 1930-33, the years of Nazism's climb to true national power, the 
diplomats serving in Berlin often ignored the similarities of Nazism and Italian Fascism, reporting on Nazism as a possible offshoot of Communism, or as a destructive ideology that would damage Weimar society to the point that Communism could triumph in the ensuing chaos.

The Berlin diplomats ignored the Italian connection for many reasons. Among these were the following:

1. The fundamental differences between Nazism and Italian Fascism. The Nazis were rightly viewed as much more destructive and a greater danger than Mussolini's Fascists, and there were many significant differences between the two regimes, some of which will be reviewed herein.

2. The similarities between Russian Bolshevism and Nazism. These did exist, and it is worth noting that both these ideologies were much more extreme than Italian Fascism, particularly during the period under discussion.

3. The position of Bolshevism as a synonym for "chaos" in the minds of American diplomats and leaders. This strong aversion to Bolshevism made Americans and their allies, the British, particularly attuned to the possibility of the spread of Bolshevism in Western Europe. The Soviet Union's propaganda and policy of debt repudiation were particular concerns, and debt repudiation became a major concern of American 
diplomats in the chaotic financial environment of Weimar Germany.

4. The favorable reaction of many American government, business and media leaders to Mussolini's regime. Although Mussolini's popularity in the United States declined after his 1935 invasion of Ethiopia, his leadership was often presented in a favorable light because of his actual achievements and his unusually astute public relations campaign in the United States. The American reaction to the Nazis was more uniformly unfavorable from the start, and was affected by Hitler's relative lack of interest in influencing American opinion.

5. The business-oriented emphasis of American foreign policy in the 1920 s and early 1930s. Under the Republican administrations of this period, financial stability in Europe was a prime concern. The cycle of war debts and reparations payments was important not only to the official diplomats but to the many business leaders who served as unofficial diplomats during this period. The Nazis represented a major threat to this cycle and to the prompt repayment of debts. Their policies, when identifiable, seemed to have more in common with Bolshevik debt repudiation than with Mussolini's favorable attitude toward foreign investment. 
B. The "Bolshevism bogey" as a central tenet of Weimar Republic foreign policy. Weimar leaders were aware of American and British fears of Bolshevism, and had made the exploitation of these fears a part of their strategy since the Versailles Peace Settlement. Throughout the 1920s, Foreign Minister Gustav Stresemann used the fear of creeping Bolshevism in Germany to help him achieve German foreign policy objectives. A stable, economically healthy Germany would be far less vulnerable to the enticements of communism.

7. Ideas of national character. The American diplomats and press still held strong ideas of the "national character" of the different nations of Europe. Many of these ideas had to do with whether a particular nation was prepared for democratic self-government. The traditional image of the Italians as contentious, hot-headed Latins coincided with the view that they needed strong leadership such as that provided by Mussolini, whose virtues appeared to outweigh his faults. Yet in Germany, a nation much more crucial to American political and financial interests, a dictatorship appeared far more dangerous, particularly when accompanied by the destructive activities of the Nazi party. As the Germans were traditionally perceived in America as an orderly, decent, dependable 
people, the Nazis appeared even more anomalous. The views of American diplomats were overwhelmingly in favor of maintaining the representative government of the Weimar Republic. Their view was that the Germans should be ready for self-government, although their experience of it was quite limited and the revival of the monarchy or Prussian militarism was always a possibility.

8. The perception of Hitler as a man not in control of his party. Despite the extreme degree of control Hitler had over the Nazis, the actual party activities during the period of the Nazi rise to power included much that appeared to be chaotic mob activity, though it was actually carefully organized mob activity. Also, Hitler's principle of "rival authorities" led him to maintain wings of the party, such as that of Gregor Strasser, that emphasized the socialist element of National Socialism in order to gain votes in communities with leftist sympathies. The Nazis would espouse any kind of ideas whenever convenient to get votes, and this added to the confusion that already existed because of their lack of a coherent party program. Hitler was widely underestimated by observers of all nationalities, and given Mussolini's image as a "statesman" of sorts, many thought Hitler could never become a leader of comparable stature, and 
that he could not even control the elements of his existing party.

9. The antecedents of the diplomats themselves. American diplomats of the period were generally men of high social and economic standing and considerable propriety, and they were thus particularly fearful of Bolshevism, debt repudiation, and economic chaos. Hitler appeared to them as a proponent of economic chaos and repudiation, unlike Mussolini, who had worked to create a stable business climate in Italy. The vulgarity and violence of the Nazi party seemed more related to Bolshevism than to the relatively placid Fascist Italy of the time. Mussolini reinforced this by disassociating himself and Fascism from the worst activities of the Nazis, and by constantly declaring that he had saved Italy from Bolshevism.

10. Personal connections between Weimar Republic leaders and American diplomats. The most notable example of this is the relationship between Chancellor Heinrich Brüning and American Ambassador Frederic Sackett in the early 1930s. Sackett and Brüning became close friends, and the ambassador dedicated considerable energy to helping the embattled Chancellor to stay in office and solve the problems of the German economy. On more than one occasion, Sackett communicated 
directly with President Hoover regarding Brüning's alarm about Communism in Germany at a time when Nazis was the major opposition. Since Sackett was trying to get Hoover to hold an economic conference to help Brüning deal with the German reparation problem, it is quite plausible that Sackett and Brüning turned to the "Bolshevism bogey" as a more alarming threat to order and therefore a more effective way to get the attention of a President preoccupied with the domestic problems of the Great Depression.

Along with the views of the American diplomats on Bolshevism, Fascism, and Nazism, representative views by British diplomats will also be included in this study. This is partly because of the cooperation that arose between the British and American leadership after World War I, thanks to their status as the two major status quo powers in the world (and in spite of their lasting naval and financial rivalry). While the views of American and British diplomats on Fascism, Nazism, and Bolshevism were by no means identical, there was a notable degree of agreement between the diplomats of the two nations regarding these new and baffling political phenomena.

Also, the traditionally close British foreign policy elite was far more open about its views, at least among its own nembers. As D. Cameron Watt has noted: 
The British practice of conducting most of the debate by witten records, when taken with the normal practice among those in constant social relationships with one another of confiding their thoughts and experiences to private correspondence diaries, journals and the like, is a gift beyond treasure to twentieth-century historians.

(1)

The American foreign policy elite was in some cases as closely connected as the one in Britain, but they did not always write down all their views with the same degree of candor. The author hopes that the additional views of the British diplomats will help to shed light on the American perceptions and increase understanding of the position of two established national powers confronting new and dangerous ideologies abroad. 


\section{ENDNOTES}

(1) D. Cameron Watt, "Foreword," in B.J.C

McKercher, ed., Anglo-American Relations in the 1920s: The Struggle for Supremacy (Edmonton, 1990), xii. 


\section{CHAPTER II}

\section{THE ANGLO-AMERICAN DIPLOMATIC BACKGROUND}

The First World War left behind a host of lasting problems, and these difficult matters -- the European war debts, the German reparations question, and the emergence of Soviet Russia --were the sources of America's interwar European policy concerns. The Versailles Treaty that ended the war had left no party satisfied, yet it demonstrated a sincere effort by the victor powers to "lay the basis of a stable and secure world while combating the forces and destroying the roots of bolshevism."

During the creation of the treaty, President Woodrow Wilson had feared for the future of Germany:

A harsh peace he could accept; but an unjust peace, Wilson warned, would drive Germany into the hands of the Bolsheviks or engender an atmosphere of lasting enmity and permanent revenge. The president wanted Germany to pay for her mistakes, but he also wanted to reintegrate Germany into a postwar liberal capitalist order that would be both prosperous and stable. (2)

This reintegration of Germany proved to be a most difficult task. The Versailles Treaty was perceived by many Germans as the worst kind of betrayal and defeat. As the Weimar Republic of 1919 to 1933 grew out of the circumstances surrounding the treaty, it was tainted with "complicity" in 
the minds of many Germans. (3) To complicate matters, the problems of reparations and war debts were left unsolved by the treaty and formed the subject matter of continuing international disputes lasting through the 1920 s and well into the 1930 s.

The United States had rejected the Versailles Treaty and Wilson's League of Nations, and seemed outwardly to have withdrawn from Europe's problems. This has led some historians to describe the interwar period as a time of "isolationism." However, the United States did have clear policy goals in Europe, which included encouraging moderate change and bolstering economic prosperity in order to prevent revolution. The underlying motivation was "fear of chaos." (4) In 1931, a State Department spokesman described "Prosperity and Peace" as the goals of American policy:

They imply a prosperous world with which the United States shall be free to trade on terms of equality with the other nations, and a peaceful world in which the United States shall be free to develop its resources without dissipating those resources or distracting its statesmen in providing for immediate national defense. (5)

During the interwar years, America's Republican administrations were deeply concerned with German rehabilitation and French demands for security, yet they also sought to balance internal and external economic concerns and remain aloof from European political 
entanglements. (6) Since "international friction and political uncertainty were anathema to the complex network of high finance and big business," American policy supported stability wherever it could be found, in regimes ranging from Germany's moderate Weimar Republic to rightwing dictatorships such as Mussolini's Fascist Italy.

Whatever the flaws of these regimes, they were infinitely preferable to the frightening new alternative of revolutionary communism. The Bolshevik Revolution in Russia had left a strong impression on American leaders, as can be seen in the postwar "Red Scare," which left the nation "hag-ridden by the spectre of Bolshevism" according to one British observer. (8) The American outrage with the Soviets was so persistent that the United States did not recognize the Soviet regime until 1933. In every subsequent case of European economic instability, American leaders saw Bolshevism as a possible and even probable result if economic order could not be restored. Herbert Hoover, who directed the European food relief program at the end of the war, saw full stomachs and economic rehabilitation as the only way to save Eastern Europe from "Bolshevism and rank anarchy." As he noted, "Bolshevism spreads like a disease, and is no respecter of national borders." (9) Bolshevism had horrified most Americans with its atheism, denial of personal liberties, and repudiation of debts. This was even more true of the 
American diplomats of the period, who represented the oldfashioned, upper-and middle-class, Ivy League element that had long predominated in the Foreign Service.

In the years preceding the recognition of the Soviet Union in 1933, American anti-communism centered upon two salient issues: the specter of "world revolution" and the Bolsheviks' repudiation of their predecessors' debts and treaties. In the minds of most American diplomats, there was no way the United States could maintain civilized relations with representatives

of a group who hold it as their mission to bring about the overthrow of the existing political, economic and social order throughout the world and who regulate their conduct towards other nations accordingly. (11)

Bolshevism constituted both an ideological and an economic threat to the American position in Europe. The ideological threat, of course, was Bolshevism's "dominating world revolutionary purpose." (12) American diplomats may have overestimated this factor, as they were disadvantaged by their lack of firsthand observers within the Soviet Union. Even when communism did not pose a serious threat within a given nation, the perceived threat of it kept American diplomats wary and also colored their perceptions of new ideologies such as Italian Fascism and German Nazism. Benito Mussolini, who came to power within five years of the Bolshevik Revolution, claimed to have saved Italy from communism. In Germany, the Weimar Republic's 
leaders throughout the twenties were highly attuned to American fears of Bolshevism and used them to gain leverage for their own interests, even in the early 1930 s when the Nazis constituted a far greater threat to republican government.

The same fears of contagious Bolshevism colored American diplomatic perceptions in other areas around the world. The "ideological blinders" of anti-Bolshevism permeated the State Department and affected interpretations of indigenous revolutionary movements in Mexico, Central America, Greece and Spain. (13) Indeed, given the American diplomatic obsession with communism in the 1920 s and early 1930s, almost any revolutionary ideology, whether it arose on the right or the left of the political spectrum, was bound to be interpreted in terms of communism.

The second of America's great fears of Bolshevism was economic, and involved the Soviet Union's repudiation of debts incurred by previous Russian regimes. As the leading creditor nation of the world, the United States was bound to be sensitive to this breach of international goodwill and the example it might offer to European debtor nations. In a press release issued in 1923, Secretary of State Charles Evans Hughes expressed the State Department's indignation regarding this issue:

Now what did the Soviet authorities do? In 
their Decree of January 21, 1918, they made this simple statement: "Unconditionally, and without any exceptions, all foreign loans are annulled."

What was loaned to Russia out of our Liberty Bond proceeds, and the war loans obtained by Russia before the revolution to enable Russia to continue the war were simply annulled! Now the United States is not a harsh creditor. The United States is not seeking to press debtors who cannot pay beyond their means. But indulgence and proper arrangements are one thing, repudiation is quite another.

Throughout the twenties, American policy spokesmen vented their anger about the Soviet repudiation of debts. If there had been any fear that this sort of thinking could spread to Italy, Mussolini soon put a stop to it. Upon becoming premier, he made his views clear to newsmen: "One must always speak well of his creditors, and we owe the United States money." He also noted his desire for close relations and an economic entente between Italy and the United States.

The situation looked much different in Germany when the Nazis began their rise to power with their phenomenal election victory of 1930. Their victory set off an immediate alarm in the minds of the American diplomats in Berlin, and that alarm was largely economic. (16) Not only had the Nazis increased their representation in the Reichstag from 12 to 107 seats, but the Communist Party had also made an impressive showing. The "extraordinarily confused, self-contradictory and opportunist" Nazi campaign 
contained ominous hints of "repudiation pure and simple" of all foreign obligations, financial and diplomatic. The American charge' d'affaires in Berlin, George A. Gordon, decried the behavior of solid citizens who voted for the Nazis even though their action could only

further impair foreign confidence -- especially in financial circles -- in the stability of German republican institutions and, in general, to intensify the economic and financial evils of which they complain. (17)

The fear of repudiation recurred constantly in discussions of the Nazis throughout their rise to power in the early 1930s. At this time it was becoming clear to observers that the republic could not survive intact, yet no one could foresee how it would be modified or replaced. The Americans and their allies, the British, had invested wholeheartedly in the preservation of the Weimar Republic. Not only was the U.S. embroiled in the complicated cycle of German reparations and Allied war debts, but it had invested heavily in German governments from the Reich to the municipality level and in the private sector as well. When the Nazis began to threaten that investment with their dangerous rhetoric and actions, American diplomats turned to various models in order to try to interpret their confusing, exasperating, ever-changing ways. For reasons largely connected with their financial fears, Bolshevism was one of the first models they used to explain the Nazis; Italian Fascism, which represented a system congenial to 
the Anglo-American status quo, would ironically be one of the last and least used analogies. To understand why Italian Fascism, one of Nazism's chief ideological sources, did not offer the diplomats a credible parallel with Nazism, it will be necessary later on in this work to explore the relationship between the United States and Mussolini's Italy in the 1920s and early 1930s.

To understand the diplomatic reaction to Bolshevism, Fascism, and Nazism, it is also necessary to examine the backgrounds of the diplomats who did the reporting. The Foreign Service, like many American institutions, underwent a rapid expansion and professionalization after World War I as the United States assumed a major role on the world stage.

As America entered the twenties, the nation was emerging from a period of upheaval that had fundamentally changed its values and organization. Historian Robert $H$. Wiebe has referred to the period between 1877 and 1920 as that of "The Search For Order," and has noted the change from the old America of small-town, community-based values to the new America of increased urbanization, bureaucracy, and government involvement in the nation's life at every level.

The early years of the twentieth century, commonly referred to as the Progressive Era, had been followed by the First World War, which greatly accelerated the 
transformation of the United States from an insular nation to a major player on the international stage. No longer would America's foreign policy be merely a series of reactions to unrelated "incidents" abroad. The war years created an entrenched federal bureaucracy in both domestic and foreign relations, and aided in the creation of a new out look:

A bureaucratic orientation now defined a basic part of the nation's discourse. The values of continuity and regularity, functionality and rationality, administration and management set the form of problems and outlined their alternative solutions. (19)

This trend toward professionalization of diplomacy had been helped along by the efforts of elites working to increase American profits and power abroad. From the 1890s on, these groups worked to impose "a crude order" on the existing rudiments of American diplomacy. Men such as John Hay, Elihu Root, Henry Cabot Lodge, Theodore Roosevelt, and Alfred Thayer Mahan had fought to increase America's role in the world and the federal government's role in the creation of a coherent, lasting foreign policy. Their views were a major factor in creating the businessprogressive foreign policy of the interwar years:

During the twenties a new set of public officials would fashion an approach out of the expansionist ideas of Roosevelt's coterie, the bureaucratic inclination of the progressives, and the balance-sheet philosophy of big business . . . (20)

Historians such as Ellis W. Hawley and Michael Hogan 
have conceptualized this period as one of "corporatism" or "associationalism," drawing on the work of business historians such as Robert H. Wiebe and Alfred D. Chandler. Among the features of corporatism is a pattern that can be seen repeatedly in the history of American interwar relations with Europe; in such a system,

elites in the private and public sector collaborate to guarantee stability and harmony; and this collaboration creates a pattern of interpenetration and power sharing that of ten makes it difficult to determine where one sector leaves off and the other begins.

The strong financial emphasis of American interwar policies led to numerous such private/public sector collaborations as the Dawes and Young Plans for German reparations revision, the "bailing out" of the Weimar Republic with American loans, and the close business-based relations with Mussolini's Fascist Italy.

Meanwhile, standardization and professionalization were also reaching the American foreign service where only an "amateurish approach" had existed before. (22) This growth began in the 1890 s and was greatly accelerated by World War I. By the end of the war there were five times as many State Department employees as there had been in 1898. University education in world affairs, almost nonexistent in 1906, had mushroomed in growth by the early 1920s, facilitating the training of a new generation of professional diplomats. The general public's interest in 
foreign affairs also increased. A generation of professional foreign correspondents arose, reporting on European political, social and cultural affairs from a mature perspective, and leaving aside the light, gossipy emphasis of previous times.

However, American diplomacy in the 1920 s and 1930s was still mired in its pre-World War I legacy, using "the concepts and methods of a small neutral nation." George F. Rennan, writing in 1950, looked back to this approach,

for which I must confess a certain nostalgia . . . The Department of State as it existed at the turn of the century, and as it still was in large measure in the $1920^{\prime} s$ when I entered it, was a quaint old place, with its law-office atmosphere, its cool dark corridors, its swinging doors, its brass cuspidors, its black leather rocking chairs, and the grandfather's clock in the Secretary of State's office. There was a real old-fashioned dignity and simplicity about it. (24)

Important changes were occurring in the Foreign Service during this period, as the Rogers Act of 1924 created a professionalized and ostensibly more equitable diplomatic corps. By providing pensions, travel allowances, higher salaries, and standardized entry examinations, the Rogers Act was instrumental in opening the diplomatic profession to new men who did not fit the "aristocratic generalist" model of the old-fashioned diplomats. This landmark piece of legislation also merged the diplomatic and consular services, but consular officers, who handled the "vital but mundane" commercial 
matters in foreign nations, were still held in lower esteem by the regular diplomats, who handled the more prestigious political matters abroad and traditionally represented a higher stratum of society. The coming of the Great Depression in 1929 had a negative effect on the reforms of the Rogers Act, as diplomatic salaries, perquisites, and promotions were reduced. The diplomats were demoralized by these measures, and serving abroad became even more difficult for those lacking independent means.

The State Department also had to address the relative lack of interest in foreign policy that characterized the Republican presidents of the twenties and early thirties. Presidents Harding and Coolidge were both well-known for leaving diplomatic matters to be handled by the Secretary of State, and for not supporting the State Department in conflicts with Congress. President Hoover had far more experience and interest in foreign affairs, but was fettered by the need to deal with domestic problems arising from the Great Depression.

Within their institutional framework, Foreign Service officers shared many of the nativist and pro-business beliefs typical of America in the 1920s. They were strongly oriented toward maintaining a world safe for free trade and rational, diplomatic settlement of international disputes. They were suspicious of immigrants and shared the common prejudices against southern and eastern 
Europeans. (27) Their views on "national character" and the readiness of different nationalities for democratic self-government colored American policy toward Mussolini's Italy and other right-wing regimes.

The American diplomats were not alone in their efforts to preserve international stability for in the interwar years, American leaders discovered a much closer affinity with British leadership than they had felt in the past. The conflicts between the two nations had stretched back to the American Revolution and continued with the War of 1812 and the Civil War. In the subsequent scramble for empire, naval supremacy and markets, the two nations had frequently been rivals. World War I had changed much of that. The United States, formerly one of the world's leading debtors, had become its leading creditor. European political instability, which had sometimes worked to the advantage of the United States in the past, was now anathema to American business interests trying to take their dollars and ideas around the globe. In matters of naval supremacy the old Anglo-American rivalry remained strong, but American and British leaders began to see eye-to-eye on many more issues than in the past. This affinity arose out of what were correctly perceived to be common interests -- the maintenance of peace and stability around the world and particularly in Western Europe, to ensure that business could be carried out efficiently by both nations. 
The war brought more than just an end to old empires and a drastic change in the status of Britain and America. New nations and divisions of territory emerged out of the Versailles Treaty as the victor powers determined the disputed status of lands belonging to the former empires. The most alarming development, however, was the emergence of Bolshevik Russia, a new nation with a new ideology, created upon the wreckage of the old Tsarist empire.

This new state was a threat to everything the Americans and the British stood for -- stability, peace, and expanding financial empires. The Bolsheviks proudly declared their desire for world revolution and refused to honor the debts of the Tsarist government or compensate individuals and corporations for the loss of their property. These values were so far from the prevailing Anglo-American views that the possible spread of Bolshevism became an overwhelming fear of British and American policymakers. This fear was manifested in many ways, some obvious, such as the American postwar "Red Scare" and the virulent anti-Bolshevism of Winston Churchill, and others less visible. One lesser-known way in which fears of Bolshevism affected policy was that of Anglo-American reactions to other emerging ideologies, such as Italian Fascism and German Nazism.

The social background of the diplomats affected their views on this subject to a great degree. High-ranking 
American diplomats of the period, such as Joseph Grew, Hugh Gibson, and William Phillips, were members of an elite group of old-style diplomats who felt a natural affinity for the European upper classes. To these men,

communism was anathema. As Christian gentlemen, the diplomats were horrified at the assault upon family, religion, and simple decorum that gained popularity with the Bolshevist revolution in 1917

Jay Pierrepont Moffat, a high-ranking American diplomat of the era, exemplified this attitude in his memories of life in Warsaw in the early 1920s:

Theoretically, communism embodied a conception of life far more advanced than our own system, yet in practice it was reviving the Dark Ages. It required an act of faith to see a happier world growing out of the misery and torture and carnage that followed wherever the early Bolsheviks trod. And yet we instinctively knew that the Polish way of life, twentieth century feudalism however benevolent, was doomed to die. (30)

The old American foreign policy elite, which was still very much in control in the 1920 s, had its counterpart and model in the diplomatic elite of Great Britain. The British Foreign Office had itself undergone reforms in 1906 and 1919-20, but these changes, like the American reforms, were a method of acknowledging expansion and changes in the existing elite, not a thoroughgoing opening of the diplomatic profession to all classes of society.

In the interwar period, there was a new emphasis on Anglo-American cooperation in foreign policy. During this period there was a common feeling, particularly among some 
British diplomats, of a "Trans-Atlantic Anglo-Saxon

family," exemplified by the title of Churchill's History of the English-Speaking Peoples. (32) Anglophilia had been strong among the older American imperialists such as Theodore Roosevelt and Alfred Thayer Mahan, but was modified somewhat by the new need to recognize and accommodate American power after World War I. (33) The United States, as creditor to the world, was now the "senior" partner in the Anglo-American financial relationship, often to the exasperation of the British diplomats who were forced to accede to American whims.

As one British policy statement noted,

The American characteristics of emotionalism, ignorant irresponsibility in high place, and -- lower -- whirlwind press campaigns, abide. Nor can dispassionate review overlook on the one hand a certain commercial imperialism, on the other a new superiority which.. . tends to promote a slightly aggressive expectation -of ten confirmed -- of having things one's own way. (34)

Another British diplomat complained profusely about the problems of dealing with the Americans, but recognized the inevitability of cooperation with them:

Politically, with their natural tendency to isolation and their relative remoteness from European problems, it can hardly be denied that the United States stand to gain less from our friendship than we do from theirs.. . Financially, we are unguestionably more dependent on the United States than the United States are upon us. (35)

The Americans had considerable control over the 
relationship because of their newfound money and power, but the British still saw themselves as the senior partners in terms of judgment and expertise:

With our older traditions and wider experience it should be possible here to take a longer and steadier view... . Americans are notoriously hasty and impetuous in their judgments and the actual advantages which they derive from good relations with Great Britain are patent only to a relatively small and thoughtful minority.

Bitter battles erupted between the two nations during the interwar period, particularly regarding questions of naval supremacy. (37) Yet there was also a sense of shared Anglo-American objectives, often in opposition to the policy objectives of the French, the Germans, and other Europeans. This was reinforced by a new sense of kinship between the American and British policymaking elites and a new sense of equality on the part of the American leaders. Speaking of the patrician Secretary of State Henry L. Stimson, one biographer notes that "Stimson and those who shared his education and background instinctively thought themselves the equals of the British and the superiors of everyone else." In keeping with this kind of thinking, American Ambassador to England Alanson B. Houghton, in a conversation with British Foreign Minister Austen Chamberlain, even quoted Kipling on "the difference between the great Anglo-Saxon nations and 'the lesser folk without the law..."

In the period after World War I, the British and 
American upper classes strengthened their ties in banking, law, diplomacy, and academia through such institutions as the Rhodes Scholarships and the Pilgrims' Society, established to bring together opinion-makers from both nations for charitable and political enterprises. The British, embattled by problems throughout their worldwide empire, found support among the American diplomats, with whom they often developed personal friendships:

The interwar period was the time when the tight, sharply defined ruling class in England and its more diffuse but still recognizable counterpart in the United States, after a century of mutual dislike, began to make friends. Very often they did so as individuals.

For example, Sir Ronald Graham, the British Ambassador to Italy, spoke of his American counterpart, Henry Fletcher, as having "shrewd judgment" representative of "the best opinion here," and being "entirely of my way of thinking" regarding questions of Mussolini's ambitions. R.L. Craigie, a leading British diplomat in Washington, noted that he and William Castle, the mercurial Assistant Under-Secretary for Western European Affairs, were "old friends." (40) In the highest levels of the diplomatic service, Sir Esme Howard, the British ambassador in Washington from 1906-08 and 1924-1930, had many friends among the "Eastern establishment" of the day, including James Garfield, Oliver Wendell Holmes, and former Secretary of State Elihu Root, all close friends of Secretary of 
State Stimson. As an "Atlanticist" and admirer of American inventiveness, Howard was very aware of the role AngloAmerican cooperation could play in maintaining peace and security around the world. His highly successful tenure as ambassador demonstrated that British interests could be best served by a man who already commanded the friendship and attention of many members of the American elite.

The British and American elites "shared tastes, values and prejudices." (42) This was certainly true of their parallel responses to Bolshevism, which horrified the British leadership for many of the same reasons as it did the Americans. As one British diplomat plainly stated,

. . the Bolsheviks consistently and deliberately set at nought a whole number of principles which we consider essential in right thinking communities: they repudiate debts and they engage in propaganda. (43)

The British maintained a more cordial posture towards the Soviets than did the Americans, but their citizens had major uncompensated losses that were a source of lasting animosity. In 1929, these losses were estimated at $\$ 180$ million for nationalized properties, 40 million in repudiated pre-war State and municipal securities, $\$ 35$ million in confiscated property and money, and a Russian war debt to Britain of $\$ 800$ million.

Back in England, trade unions went on strike against British support of the anti-Bolshevik White Russian forces, and leading Conservative politicians such as Winston 
Churchill railed against Communism. The British did not normalize relations with Russia until 1924. Many British Conservatives exhibited "an exaggerated fear of domestic communism" that furthered their desire to isolate the Soviets, and they persisted in seeing the Communists as the chief danger to international security even well after the advent of the Nazis. In much the same way as the Americans, the British wanted to isolate Russia, and thus supported the Weimar Republic as a bulwark against Russian expansionism .

While the United States persisted in non-recognition of the Soviet Union until 1933, British relations with the USSR "fluctuated between uneasy co-operation and open hostility," reaching a nadir in 1927 when the British broke off diplomatic relations after discovering evidence of espionage and subversion by Arcos, the Soviet trading organization. British exports to the USSR fell from $\mathbb{2} 36$ million in 1925 to $\not 11$ million in 1928. Relations were reopened in 1929, but suspicion and hostility still colored the relationship.

The British, like the Americans, were openly devoted to the preservation of peace, the status quo, and their own commercial interests on an international level. (47) A leading British saw these objectives as leaving them "diametrically opposed" to the policies of the outlaw Bolshevik nation: 
British policy aims at securing the safety of the Empire and the promotion of its trade, upon which its life and prosperity are based. For this purpose we are working everywhere for peace and settlement, with a view to achieve a return to normal economic conditions. Russian policy, on the other hand, aims at the establishment of communism, which it can only achieve by the destruction of the present order of

things. To promote this revolution it aims at fomenting disturbance and disorder everywhere. (48)

As in the American case, British hostility toward Communism was matched by comfortable relations with Mussolini's Fascist Italy, which appeared, despite its problematic aspects, to be a valuable ally in the preservation of the status quo. Sir Austen Chamberlain, head of the Foreign Office, wrote proudly of his "personal relationship" with Mussolini. (49) He believed, as did the Americans, that Mussolini had redeemed Italy from "political corruption, social anarchy, industrial strife and national degeneracy" and had given "a new life and a new standing to Italy." (50) He was not alarmed by Mussolini's sometimes bellicose rhetoric, which he felt was only bluff and attention-seeking:

Signor Mussolini's methods are sometimes a little rough; he is apt to fancy a slight and to go off at a tangent, but I have found him a man of his word, and we have settled without any serious difficulty two or three questions which in other hands might have given rise to a serious crisis. (51)

Sir Ronald Graham, the British Ambassador to Italy, acknowledged the worst aspects of Mussolini's regime in the 
area of personal liberties, yet insisted that "the good outweighs the evil" and that Mussolini was bringing "progress and development to millions of people." (52) In the British view, the Italians were "nationally inclined to disobedience of the law" and had a "national inaptitude for organization." The emergence of Mussolini, who was developing Italian industry and transportation and "stamping out communism," seemed a blessing. An added bonus was the "loyalty and goodwill" of Mussolini's capable Foreign Minister, Dino Grandi, with whom high-ranking British and American diplomats, such as Sir Ronald Graham and Henry L. Stimson, felt very much at ease. Grandi noted the new sense of Anglo-American unity and the cordial treatment he received from both nations. Good relations were further enhanced by Grandi's successful visit to the United States in 1931 and his appointment as Mussolini's minister to Great Britain in 1932.

While American business and diplomatic relations flourished in Italy, the nation became ever more isolated from the new regime in Russia. Under the tutelage of Robert F. Kelley, the rabidly anti-Bolshevik chief of Eastern European affairs, aspiring American Foreign Service officers were educated in the ways of the old Russia, and "the perspective that the Soviets had destroyed all that was of value in Russian life" would color the views of State Department Soviet experts for years to come. 
These views helped delay the recognition of the Soviet Union despite the widespread sympathy of American intellectuals toward the Soviet experiment and the increasing demands of businessmen, particularly after 1927, to expedite trade with Russia through recognition of the Soviet government.

The prevailing atmosphere of continuing isolation from the Soviet Union only intensified fears and suspicions of communism. Before the Americans recognized the Soviet Union in 1933, nearly all of their information on Russia came from an observation post in Riga, Latvia, manned by newly trained experts on Russia, such as George Rennan and Charles Bohlen. The city of Riga itself provided few insights into the new Bolshevik regime, for as Rennan described it, "To live in Riga was. . . in many respects to live in Tsarist Russia--it was, in fact, almost the only place where one could still live in Tsarist Russia."

The American "Soviet Service" was opposed to recognition. Their perceptions, dubbed the "Riga Axioms" by one historian, were highly influential in American policy. They included the view that the Soviet Union demanded expansion and further revolution, and always created its foreign policy through "ideology and conscious intentions," never by accident. (57) These views played a role in American reaction to the European political upheaval of the interwar years and continued to influence 
American policy well into the years of the Cold War.

American diplomats shared a "liberal-internationalist concept of international relations" which put a high priority on free commercial relations and respect for public opinion, values that had been repudiated to a great extent by the fledgling Soviet Union. (58) In Italy, Mussolini remained attuned to these American priorities, but Hitler disregarded them from the start, and this inevitably affected American diplomatic views regarding these two regimes.

An overwhelming emphasis on commercial relations colored American foreign policy throughout the 1920 s and early 1930s. The old-fashioned diplomats, with their Ivy League background, held a certain disdain for business (60), but the pre-Depression faith in business and businessmen carried over from domestic policy into the field of international relations. Herbert Feis, the State Department's Economic Adviser from 1931 to 1943, has noted that "during the decade of the twenties, the dollar figured large in our relations with other nations. We acted as banker to the whole needy world. . " with private capital providing funds and the United States government involved in the operations.

This move to financially-oriented diplomacy set the tone for American diplomacy for this entire period. Diplomats, bankers and businessmen worked toward the same 
goals, sharing "a common set of assumptions concerning the inseparability of American economic progress, world peace, and European economic and political stability." They saw German recovery as essential to European prosperity, American economic growth, and the restriction of Bolshevist expansion. However, Germany's needs had to be balanced against the French concern for security and the Allied desire for German reparation payments. The Americans produced a "corporatist" solution which delegated the settlement of European financial matters to "experts" from the American business world, all in an effort to stabilize Europe's economy while not getting overinvolved in its politics. (62)

The prevailing disillusionment following World War I had produced a marked change from Wilsonian internationalism to the semi-isolationism of the 1920s. In December 1920, Wilson's last State of the Union address championed America's mission as an example of democracy in a world shaken by the Bolshevik Revolution (63), yet six months later, President Harding's address to Congress emphasized America's rejection of the League of Nations and expressed a pragmatic, distant attitude toward Europe and its problems:

We can be helpful because we are moved by no hatreds and harbor no fears. Helpfulness does not mean entanglement, and participation in economic adjustments does not mean sponsorship for treaty commitments which do not concern us, 
and in which we will have no part.

(64)

"Economic adjustments" in Europe were at the center of Republican foreign policy in the twenties. Many historians have noted the American avoidance of political entanglements coupled with a willing intervention in European economic policy, often using "unofficial" diplomats from the business world as its agents. (65) The Dawes and Young plans for revision of reparations were examples of this type of diplomacy, which was praised by President Coolidge in 1924:

The attitude which our Government took and maintained toward an adjustment of European reparations, by pointing out that it was not a political but a business problem, has demonstrated its wisdom by its actual results. We desire to see Europe restored that it may resume its productivity in the increase of industry and its support in the advance of civilization. We look with great gratification at the hopeful prospect of recuperation in Europe through the Dawes plan. Such assistance as can be given through the action of the public authorities and of our private citizens, through friendly counsel and cooperation, and through economic and financial support . . . should be unhesitatingly provided. (66)

Over the course of the 1920s, it became apparent that the reparations problem was part of a larger European pattern of change and conflict that could not be dismissed as simply a "business problem." However, in the early interwar period, the United States still held faith in the ability of American financial strength to help maintain stability in Europe. Over the years this proved to be 
untrue in Weimar Germany, but it seemed to work well in Mussolini's Fascist Italy, which will be examined next. 


\section{ENDNOTES}

(1) Melvyn P. Leffler, The Elusive Quest: America's Pursuit of European Stability and Erench Security, 19191933 (Chapel Hill, N.C., 1979), 3.

(2) Ibid., 4.

(3) Gordon A. Craig, Germany: 1866-1945 (New York, 1978), 424-425; Hajo Holborn, A History of Modern Germanx: 1840-1945 (Princeton, 1969), 578.

(4) Frank Costigliola, Awkward Dominion: American Political, Economic, and Cultural Relations With Europe, 1919-1933 (Ithaca, 1984), 260.

(5) John Carter, "America's Present Role in World Affairs," Current History 35:2 (November 1931), 162. Mr. Carter was a diplomat from the State Department's Division of Western European Affairs.

(6) Leffler, Elusive Quest, 368.

(7) Melvyn P. Leffler, "Political Isolationism, Economic Expansionism, or Diplomatic Realism: American Policy Toward Western Europe 1921-1933," Perspectives in American History 8 (1974), 429-430; Costigliola, Awkward Dominion, 260.

(8) A.G. Gardiner, Portraits and Portents, (New York and London, 1926), 13.

(9) Hoover to President Woodrow Wilson, November 9 , 1918, in Suda Lorena Bane and Ralph Haswell Lutz, eds., Organization of American Relief in Europe, 1918-1919, Publication No. 20 of the Hoover Library on War, Revolution and Peace (Stanford, 1943), 36. The second quotation is from Hoover's statement on "Problems of Relief Distribution and Finance," January 3,1919 , ibid., 145.

(10) Hugh de Santis, The Diplomacy of Silence: The American Eoreign Service, the Soviet Union, and the cold War, 1933-1947 (Chicago, 1980), 13; Martin Weil, A Pretty Good Club: The Eounding Eathers of the U.S. Foreign Service (New York, 1978), 21-22. 
(11) Frank B. Rellogg (Secretary of State to Senator Butler (Chairman of the Republican National Committee), February 23, 1928, enclosure (extract from "Statement Covering the Activities of the Department of State -- Russia"), Papers Relating to the Eoreign Relations of the United States 1828 (Washington, U.S. Government Printing office) $3: 822$ (hereafter referred to as ERUS).

\section{(12) Ibid., 823.}

(13) Douglas Little, "Antibolshevism and American Foreign Policy, 1919-1939: The Diplomacy of SelfDelusion," American Quarterly 35 (1983), 376-390 passim. For an exploration of how antibolshevism colored American reaction to the Nazis, see Bernard V. Burke, "The Nazis Through an Anti-Communist Prism: American Diplomats and Hitler's Rise to Power," paper read at Portland State University, 1987.

(14) Charles Evans Hughes, "Press Release Issued by the Department of State, March 21, 1923," ERUS 1923, 2:757. Hughes press release was a response to a delegation of the Women's Committee for Recognition of Russia. Ironically, the Bolsheviks used the American Revolution's repudiation of the previous regime's treaties as evidence to justify their own repudiation of the previous government's obligations. See Richard Washburn Child to State, May 12, 1922 , enclosure ("The Delegation of Soviet Russia at the Genoa Conference to the Delegation of Italy. . . ."), ERUS 1922, 2:798-9. Professor Bernard V. Burke has pointed out that Hughes outrage against Bolshevik debt repudiation was particularly unusual in view of his refusal to negotiate debt repudiation with the Bolsheviks or to attend the Genoa Conference in 1922 to settle outstanding issues between the two nations (Bernard V. Burke, in conversation, July 1993).

(15) New York Times, October 31, 1922, 5:5, cited in John Morris Berutti, "Italo-American Diplomatic Relations, 1922-28," Ph.D. dissertation, Stanford University, 1960.

(16) Henry Lewis Stimson Diaries, X, 81-82 (microfilm edition, reel 2) Manuscripts and Archives, Yale University Library, New Haven, Connecticut (referred to hereafter as Stimson Diaries). In this entry of October 19, 1930, Stimson describes a meeting with George Harrison, head of the New York Federal Reserve Bank, in which they discussed the need to help Germany recover economically from the "alarm created by the last election."

(17) George A. Gordon to State, September 15, 1930, ERUS 1930, 3:76; Gordon to State, September 17, 1930, 
ERUS $1930,3: 77,78$.

(18) Robert H. Wiebe, The Search For Order: 18771920, (New York, 1967), xiii-xiv.

(19) Ibid., 225, 295.

(20) Ibid., 284-285.

(21) Michael J.Hogan, "Corporatism," in Michael J. Hogan and Thomas G. Paterson, Explaining the History of American Eoreign Relations (Cambridge, 1991), 227. This article is a good summation of the corporatist view of American diplomatic history. Other useful discussions of corporatism are Michael Hogan, "Revival and Reform:

America's Twentieth-Century Search for a New Economic Order Abroad," Diplomatic History 8:4 (Fall 1984), 287-310; John Lewis Gaddis, "The Corporatist Synthesis: A Skeptical View," Diolomatic History 10:4 (Fall 1986), 357-362, and Michael Hogan, "Corporatism: A Positive Appraisal," ibid., 363-372. Gaddis, despite his doubts about corporatism as an overarching theory, agrees that it is a useful context for examination of the diplomatic history of the interwar period. See Gaddis, "The Corporatist Synthesis," 358-9.

(22) Wiebe, The Search for Order, 254.

(23) Warren I. Cohen, Empire Without Tears: American Eoreign Relations, 1921-1933 (New York, 1987), 2 . Robert D. Schulzinger, "The Making of the Diplomatic Mind: The Training, Outlook, and Style of United States Foreign Service Officers, 1906-1928" (Ph.D. dissertation, Yale, 1971), 17-18. Morrell Heald, Transatlantic Vistas: American Journalists in Europe, 1900-1940 (Kent, Ohio, 1988), 229.

(24) George F. Rennan, American Diplomacy, 1900-1950 (Chicago, 1951), 81-82.

(25) Barry Rubin, Secrets of State: The State Department and the Struggle Over U.S. Eoreign Policy (New York, 1985) 14-5, 20; Frederic Lewis Propas, "The State Department, Bureaucratic Politics and Soviet-American Relations, 1918-1938 (Ph.D. dissertation, UCLA, 1982), 130. For a detailed discussion of the Rogers Act's reforms and their effect on the Foreign Service, see Propas, 130-134.

(26) John Chalmers Vinson, "Charles Evans Hughes (1921-1925)," 128; L. Ethan Ellis, "Frank B. Rellogg (19251929)," 153; Richard N. Current, "Henry L. Stimson (19291933)," 173, all in Norman A. Graebner, ed., An Uncertain 
Tradition: American Secretaries of State in the Twentieth Century, (New York, 1961).

(27) Rubin, Secrets of State, 21.

(28) For more on the anti-Bolshevik fears of American and British policymakers at the time of the Versailles Treaty, see John Thompson, Russia, Bolshevism and the Yersailles Peace (Princeton, N.J., 1966), 13-17.

(29) Weil, A Pretty Good Club, 21-22.

(30) Jay Pierrepont Moffat, The Moffat Rapers: Selections Erom the Diplomatic Journals of Jay Rierrepont Moffat, 1919-1943, edited by Nancy Harvison Hooker (Cambridge, 1956), 43.

(31) D.C. Watt, Personalities and Policies: Studies in the Eormulation of British Foreign Pelicy in the Twentieth Century (South Bend, Ind., 1965; reprint ed., Westport, Conn., 1975), 187.

(32) Ibid., 24-25.

(33) On Roosevelt, Mahan, and other Anglophiles, see Paul A. Varg, America Erom Client State to World Power, Six Major Transitions in United States Eoreign Relations (Norman, Oklahoma, 1990), 119-123.

(34) Appendix, "Memorandum on the Foreign Policy of His Majesty's Government, with a List of British Commitments in their Relative Order of Importance," April 10, 1926, Documents on British Eoreign Policy 1919-1939 (London, Her Majesty's Printing Office), Series IA, Volume 5, 879; hereafter referred to as DBEP.

(35) R.L. Craigie, Memorandum, "Outstanding Problems affecting Anglo-American Relations," November 12, 1928, Annex to $\# 490$, DBFE $1 A: 5,866$.

(36) Ibid.

(37) For more on Anglo-American conflicts regarding naval supremacy, see ibid. (entire document, DBFP 1A:5,858875 passim). For an overview of the conflicts of AngloAmerican interwar relations, see B.J.C. McRercher, ed., Anglo-American Relations in the 1820s: The Struggle for Sueremacy (Edmonton, 1990).

(38) Godfrey Hodgson, The Colonel: The Life and Hars of Henry Stimson 1867-1850 (New York, 1990), 171. Mr. 
Austen Chamberlain to Sir E. Howard, November 5, 1925, \#473, DBEP 1A:2, 867.

(39) Hodgson, The Colonel, 173-174.

(40) Sir Ronald Graham (Rome) to Sir Austen Chamberlain, Private and Personal, July 2, 1926, \#81, DBFP $1 \mathrm{~A}: 2$, 136; R.L. Craigie, "Record by Mr. Craigie of a conversation with Mr. Castle", November 15, 1928, \#492, DBEP $1 A: 5,876$.

(41) Hodgson, The Colonel, 20-21, Stimson Diaries $X$, 19 (September 16, 1930), microfilm ed., reel 2), ibid., 114 (November 1, 1930). B.J.C. MeRercher, Esme Howard: A Diplomatic Biography (Cambridge, 1989), 74-75, 273-4, 280, 373.

(42) Hodgson, The Colonel, 174.

(43) Sir R. Hodgson (Moscow) to Sir Austen Chamberlain, October 26, 1926, \#262, DBEP 1A:2, 457.

(44) "Foreign Office Memorandum: Russia," June 18, $\# 1$, DBEP $2: 7,3$.

(45) Paul Rennedy, The Realities Behind Diplomacy: Background Influences on British External Bolicy, 1865-1980 (London, 1981), 246-7.

(46) P.A. Reynolds, British Eoreign Rolicy in the Inter-War Years (London, 1954), 63-64.

(47) Appendix, "Memorandum on the Foreign Policy of His Majesty's Government. . . " April 10, 1926, DBFP 1A:1, 846 .

(48) Memorandum by Sir W. Tyrrell, "Foreign Policy in Relation to Russia and Japan," July 26, 1926, DFBP $1 A: 2$, 103. See also Stephen White, Britain and the Bolshevik Revolution: A Study in the Polities of Diplomacy, 1920-1924 (London, 1979), 111-112.

(49) Chamberlain to Graham, January 10, 1927, \#387, DBEP $1 A: 2,709$.

(50) Appendix - "Statement made by Sir A. Chamberlain to the Imperial Conference on October 20, 1926," DBEP 1A:2, 925 .

(51) Ibid., 926. 
(52) Sir R. Graham (Rome) to Chamberlain, August 1, 1928 , \#117, DBEP 1A:5, 235, 234.

(53) Sir R. Graham (Rome) to A. Henderson, August 1, 1929 , \#288, DBEP $1 \mathrm{~A}: 6,475,473,477,478$; Graham to Henderson, July 14, 1931, \#192, DBEP 2:2, 188-9); Graham to Henderson, December $9,1931, \# 310$, DBEP 2:2, 363-5).

(54) Frederic L. Propas, "Creating a Hard Line Toward Russia: The Training of State Department Soviet Experts, 1927-1937," Diplomatic History 8 (1984), 218.

(55) Little, "Antibolshevism and American Foreign Policy, 377; Propas, "Creating a Hard Line," 212.

(56) George F. Kennan, Memoirs 1925-1950 (Boston, 1967), 29-30.

(57) Daniel Yergin, Shattered Peace: The Origins of the Cold War and the National Security State (Boston, 1977), 18, 36-37. David Mayers disputes the importance of the "Riga Axioms" and the extreme anti-Bolshevist reputation of the Russian section in his book, George Rennan and the Dilemmas of U.S. Eoreign Rolicy (New York, 1988), 25-26. The same is true of Daniel F. Harrington, "Rennan, Bohlen and the Riga Axioms," Diplomatic History $2: 4$ (Fall 1978), 423-37. For more about the Riga outpost, see Natalie Grant, "The Russian Section, A Window on the Soviet Union," Diplomatic History 2:1 (Winter 1978), 10715 .

(58) de Santis, The Diplomacy of Silence, 27.

(59) For a discussion of Hitler's generally low opinion of the United States and lack of interest in American opinion, see Gerhard L. Weinberg, "Hitler's Image of the United States," American Historical Review 69:4 (July 1964), 1006-1021, passim.

(60) Weil, A Rretty Good Club, 21-22.

(61) Herbert $\mathrm{Feis,} \mathrm{The} \mathrm{Diplomacy} \mathrm{of} \mathrm{the} \mathrm{Dollar:} \mathrm{Eirst}$ Era, 1919-1932 (1950: reprint ed., Hamden, Conn.: Archon Books, 1965), v.

(62) Renneth Paul Jones, ed., U.S. Diplomats in Europe, 1919-1941 (1981: reprint ed., Santa Barbara, 1983), xvii, xviii, xix. 
(63) Woodrow Wilson, "Message of the President of the United States to Congress, December 7, 1920," ERUS 1920, I:viii.

(84) Warren Harding, "Message of the President of the United States to Congress, April 12, 1921," ERUS 1921 I:xx.

(65) For more background on the strong economic emphasis of American diplomacy in the 1920s, see Leffler, "Political Isolationism, 415-6, and Bernard V. Burke, "American Economic Diplomacy and the Weimar Republic, MidAmerice $54: 4$ (October 1972), 211-3.

(66) Calvin Coolidge, "Message of the President of the United States to Congress, December 3, 1924," ERUS 1924, I : $x i x-x x$. 
CHAPTER III

\section{MUSSOLINI AND THE AMERICANS}

Italy, along with most European nations, had suffered tremendous losses and devastation in World War I. During and after the war, a possible triumph of Bolshevism in Italy had been a major American fear, and the Americans moved to protect their wartime allies, the Italians. State Department fears of "a second Russia" in Italy led the Committee on Public Information to conduct an extraordinary propaganda campaign designed to promote the goals of Wilsonian democracy. The CPI even offered financial support at this time to Benito Mussolini, who had not yet developed Fascism and was still "a prowar, moderate socialist editor. . the type of leader the Americans hoped to use in building a reformist middle alternative to the reactionaries on the right and the revolutionaries on the left."

The CPI and its propaganda machinery were disbanded in 1919, and Wilson's phenomenal popularity in Italy declined when he opposed Italian territorial demands at Versailles. However, Wilson's "brief but intense interlude" of popularity had helped fight of the threat of radical revolution in Italy. It "illustrated the difficulty in 
finding a middle path in Europe's polarized politics," a problem that the United States would also face repeatedly in the 1920s in Germany's Weimar Republic.

In Italy, however, a new regime arose that solved the problem of polarization by creating a one-party political system. On October 29, 1922, Mussolini became Prime Minister of Italy, toppling one of the many weak and shortIived parliamentary governments of the postwar period. His victory was achieved by the threat of an insurrection of his bands of Fascist blackshirts, the squadristi; by the timidity of Ring Vittorio Emanuele III, who refused to fight the threatened insurrection, and through the illusions of parliamentary leaders who thought Mussolini could be "tamed" by bringing him into the cabinet.

The king's assent to the takeover was quiet and undramatic, but Mussolini, an experienced journalist and propagandist, wanted to enter office with a gesture that would appear memorable and forceful. Thus arose the myth of the "March on Rome," with Mussolini and 30,000 armed Fascists presenting an "ultimatum" to the king. The reality was somewhat different -- there were far fewer than 30,000 men, and Mussolini reached Rome in a private sleeping car, but the myth endured and provided a model for Hitler's attempted "Beer Hall Putsch" of 1923.

Another favorite myth of Mussolini's was that by forcefully taking control, he had saved Italy from imminent 
Bolshevism that would have otherwise wrested control from the weak, divided parliamentary government. This was untrue --by 1922 the worst postwar labor troubles were over in Italy and Bolshevism was an unlikely development--but the myth served Mussolini well and would continue to do so for many years.

Fascism was an ideology created through action and experimentation, and patriotic anti-Bolshevism had certainly been one of its strongest original elements. Virulent anti-communists such as Winston Churchill praised the new leader's efforts to counteract communist revolutionary movements, and American political leaders, who were just emerging from the Red Scare of 1919-20, found his anti-communism equally praiseworthy.

Within weeks of the March on Rome, Mussolini told the American ambassador that Italy would be privatizing its utilities and railways, and that Americans would be included in the opportunities this change offered. Mussolini also wanted Italy to control its destiny "by economic cooperation but with independence of political entanglements," a system in perfect keeping with the American foreign policy objectives of the time--economic ties without political entanglements.

Throughout his career, Mussolini took credit for saving Italy from imminent Bolshevism. In typically florid style, the American edition of Mussolini's ghost-written 
"autobiography" explained the creation of Fascism as follows :

The old parties clung in vain to the rattling programmes. These parties had to make pitiful repairs and tinkerings in an attempt to adapt their theories as best they could to the new days. It was therefore not sufficient to create - - as some have said superficially -an anti-altar to the altar of socialism. It was necessary to imagine a wholly new political conception, adequate to the living reality of the twentieth century, overcoming at the same time the ideological worship of liberalism, the limited horizons of various spent and exhausted democracies, and finally the violently Utopian spirit of Bolshevism. (8)

Many American and British diplomats agreed. The American ambassador to London welcomed Mussolini's ascent in 1922 as "the death blow to Bolshevism." In 1926, the virulently anticommunist Undersecretary of State, William Castle, welcomed the prospect of pro-Mussolini writings by muckraker Ida Tarbell after her visit to Italy: ". . . if she should write articles which see the good in the Fascist regime, it will do away with a lot of subversive talk that goes on here."

As these views demonstrate, Mussolini's ascent to power was greeted with a general approbation entirely unlike the alarm that accompanied Hitler's rise to power a decade later. This was partly owing to one of the major differences between the two leaders: Mussolini made a point of courting foreign public opinion while Hitler, a 
master of propaganda within Germany, appeared to attribute little or no importance to the way foreigners, and particularly Americans, viewed him and his movement. Mussolini received little attention from American diplomatic and press observers before the March on Rome, doubtless because of his largely unknown status as a leader and the lesser importance of Italy as a focus of American concerns. By the time Americans began paying attention to Mussolini, his rule in Italy was a fait accompli. Hitler's rise to power, however, took a decade from the time of the Beer Hall Butsch to his assumption of the chancellorship, and he was the object of largely unfavorable international attention throughout that period. With his inflammatory rhetoric and offensive statements, his philosophy appeared to be that any publicity was good publicity, and his work as a destabilizing force in Germany, the central nation in American efforts for European recovery, guaranteed him negative international notoriety.

Mussolini, however, worked constantly to make sure the worldwide attention aimed at him would be largely favorable. His first meeting with the American ambassador after taking office as Prime Minister is a notable example. Not only did Mussolini break with protocol by taking the trouble to pay a visit to the American ambassador instead of vice versa, but he also made a point of letting him know that his government would be offering valuable trade 
concessions to the Americans at the first possible opportunity. (10) In December 1922, after a meeting to discuss the important issue of Italian immigration to the United States, the American charge' in Rome observed that "Mussolini is distinctly friendly in his attitude toward us."

From the start, foreign policy was Mussolini's primary emphasis. At first, he disclaimed any interest in foreign imperialism or the export of Fascism, though he belied this with his abortive takeover of the Greek island of Corfu in 1923 and his continuing financial and advisory support of Fascist movements around the world, including ItalianAmerican fascists in the United States and the early Nazis in Germany. By April 1925, Fascist movements were estimated to exist in forty countries, and many of them -including Hitler's early Nazis in Bavaria -- were supported by Italian arms shipments and diplomatic activity.

In the years immediately following the March on Rome, the new Italian Fascist regime was greeted with widespread approbation by much of the American public, press, and diplomatic corps. These views fluctuated over the years, and would change markedly with the 1935 invasion of Ethiopia and Mussolini's later cooperation with the Nazis. However, throughout the twenties and well into the thirties, Mussolini appeared to be a leader the Americans could tolerate if not embrace. Secretary of State Henry L. 
Stimson observed in his memoirs that the Italians were "the least difficult" of all the Continental Powers in 1931 and 1932. This changed after 1935 when Mussolini "deserted the ranks of the peacemakers," but at the time the Italians appeared as a valuable ally and Stimson found Mussolini "a sound and useful leader" willing to comply with orderly processes in foreign policy.

The American liberal and "highbrow" press took a different view of Fascism, and regularly attacked Mussolini for numerous offenses. Among these offenses were military impressment of Italian-American visitors to Italy, Fascist propaganda activities in the United States, expansionist rhetoric, repression of freedom of speech and the press, and the politically motivated murder of Socialist leader Giacomo Matteotti in 1924 , which was followed by a period of increased repression and consolidation of Fascist rule.

The American business press, however, lionized Mussolini in the early years of his regime. This was an important source of support during the twenties, a period when businessmen "enjoyed a virtual monopoly on the imagination and rhetoric of the American people....." Banker Lewis E. Pierson, the president of the Merchants Association of New York, praised the Fascists for their emphasis on "thrift and hard work," their purging of inefficiency and incompetence in government, and their 
return of railroads and public utilities to private enterprise. He also noted that "in place of the false and dangerous ideas of communism they have substituted the ideals of individualism."

In the United States, many were happy to see the Italians under Mussolini embracing such traditionally American virtues as hard work and thrift. One American perception of the Italians had always been that of a disorderly people, "an 'inferior,' indolent and debauched people" unprepared for the rigors of American-style democracy. Herbert Hoover, in his book Challenge to Liberty, observed that "the concept of Liberty had never been strongly developed in the Italian people." Edgar Ansel Mowrer, a veteran correspondent for the Chicage Daily News and a great admirer of the Italians and their culture, nonetheless described their politics as follows:
"Normal" Italy is an easy-going paternalistic country, colored by indolence, veined with favoritism, streaked with cheating and graft, peaceful, unprogressive, parasitical, where success generally comes by cunning or crookedness or the possession of influential friends, governed by old men through an old- fashioned, over centralized, monstrously ramified bureaucracy that chokes individual initiative.

Not only were the Italians incapable of self-government, Mowrer insisted, they did not even want it: "The Italian people has never desired real self-government, and has possessed only the bare semblance of it." 
While Mowrer offered a guarded acceptance of the early Mussolini regime, other Americans were more openly enthusiastic. In fact, one strength of Mussolini's regime was his astute understanding of American and British values and his extraordinarily successful propaganda efforts among Anglo-American journalists, diplomats, and observers from all categories of society. One of Mussolini's leading admirers was Richard Washburn Child, Ambassador to Italy between 1920 and 1924, who became a member of the Italian Fascist Party and later ghost-wrote and provided a foreword for the American edition of Mussolini's "autobiography." In this foreword, Child was full of effusive praise for Mussolini's physical energy and down-to-earth pragmatism, and offered several comparisons between II Duce and Child's own hero, Theodore Roosevelt. (17) As a self-declared Theodore Roosevelt liberal, Child saw in Mussolini a man of action to match his own mentor in organizing political unity "not around rights but around duties." In his view, Mussolini's new system expressed the will of the Italian people. It also emphasized a balanced budget, hard work, service, and loyalty. Most of all, it worked, and this was a tremendous appeal to traditional American pragmatic liberalism:

When Italy was staggering around after the war the only thing which worked was Italian Fascism and Mussolini; to deny it is like denying the existence of the first day in every month. 
Other progressives echoed this same admiration for Mussolini's effectiveness and his resemblance to the classic American "man of action", Theodore Roosevelt. H. Nelson Gay's Strenuous Italy, whose very title hints at the connection with Roosevelt's philosophy of the "strenuous life," lauded Mussolini's successes as "primarily and fundamentally social and economic." Using heavily statistical source material, the author noted Fascism's achievements in education, trade, public health, and other favorite target areas of progressive reformers, and praised Mussolini for being "as practical, nationalistic and determined as was Theodore Roosevelt."

Mussolini seemed in some ways to embody that American progressive ideal, the "public man," whom Robert Wiebe has described as
. . a unique and indispensable leader. Al- though learned enough to comprehend the details of a modern, specialized government, he was much more than an expert among experts. His vision encompassed the entire nation, his impartiality freed him from all prejudices, and his detached wisdom enabled him to devise an equitable and progressive policy for the whole society. . . Because he could best determine where and how the government should expand or contract, he should have the broadest discre- tionary power, including the right to bend unnecessarily rigid constitutional limitations.

Wiebe noted that Mussolini appealed strongly to the faction of progressives who thought primarily in terms of efficiency and economy, and he shared the traits of 
"effervescence," showmanship and "insatiable ambition for power" that had characterized Theodore Roosevelt, a man who had considerably expanded the powers of the American presidency. (20)

The impression of Mussolini as a dashing man of action was carefully nurtured by Margherita Sarfatti, a leading Italian writer, art critic, and the longest-lasting of Mussolini's many mistresses. Signora Sarfatti, with her journalistic skills, social prominence and excellent command of English, was one of Mussolini's key contacts with foreign journalists and diplomats. She wrote The life of Benito Mussolini, an adulatory biography in English, in response to interest in Mussolini by an English publisher. The book, published in 1925, sold extremely well in England and the United States, and was republished with some changes in an Italian-language edition called Dux (the Latin form of Duce), which became a cornerstone of the Mussolini mythology. Sarfatti insisted that the Italians were of all nations the most addicted to hero worship, but the image of Mussolini she chose to portray in Dux was also surprisingly close to the ideal American Progressive "man of action." She even portrayed Mussolini's personal aloofness and opportunism as the traits of "an uncommon, exceptional man --a strong, ruthless leader who stood apart from ordinary human weakness." The images chosen to accompany the text were also chosen to give the impression 
of a fearless, relentless man of action:

The photographs that Dux offered were designed to suggest a range of talents beyond the abilities of most men. These included not only his roles as party activist, soldier, newspaper writer, or Fascist Duce, but also as prime minister and world statesman. Margherita was also careful to portray Mussolini as a vigorous and courageous man of action, the master of horses, airplanes, sports cars, and speedboats. (21)

This image -- later imitated by Hitler -- fit well with the "virility impulse" of certain sectors of the American progressive movement, "an exaggerated concern with manliness and its conventional concomitants -- power and activity" as symbolized in Theodore Roosevelt's charge up San Juan Hill and the nationalist/imperialist goals of such men as Albert Beveridge, Henry Cabot Lodge, and Alfred Thayer Mahan. To those Americans who continued to admire order, discipline and efficiency above all, Mussolini in his early years appeared to be a fine example of this ethic. (22)

Journalists as well as diplomats were on the receiving end of Mussolini's flattery and manipulation. During this period, American foreign correspondence and diplomacy were coming of age, but so were the techniques of modern international propaganda. Mussolini's skill as a mythmaker and propagandist made him an early leader among the practitioners of the 20 th-century art of image management, and thus "journalism and public relations were the most 
essential of all professional activities under Fascism."

(23) According to one historian of American foreign correspondents, "The first extensive postwar effort at government news manipulation occurred in the press's encounter with Benito Mussolini."

II Duce was notorious for bribing correspondents to get favorable coverage, and for expelling those who attacked him, as well as for charming away the doubts of many interviewers, particularly the female ones. Mussolini granted numerous interviews over the years, and it is sometimes difficult to account for the amount of adulation he received from astute observers who should have known better. In any case, he always made good copy for journalists by keeping them guessing and occasionally by shocking them.

Yet it is also crucial to understand the mindset with which American observers, diplomats and correspondents alike, faced European politics and Fascism's role within these politics. In Italy and Germany, the Americans were dealing with two nations largely lacking the foundations of representative government. Neither nation had been unified until the 1870 s, both were ridden with regional tensions going back centuries. Both were also dominated by fiercely partisan multiparty politics, a tradition alien to the American two-party system.

While freely acknowledging America's cultural 
inferiority to Europe, reporters were baffled by the intricacies of European politics:

Despite their disappointment with the United States, most reporters, even those who had matured professionally on the seamy corruption of urban government at home, were unprepared for the relentless, life-and-death clash of interests and national rivalries they found in the Old World. Reactions ranged from hasty idealization of the men and movements seeming to offer new directions for a war-weary, disillusioned age, to cynicism and disgust at entrenched selfishness, greed, or reaction. Although they may not have recognized it, most of the journalists were too deeply imbued with progressive American assumptions about the virtues of compromise and adaptation to change to come easily to terms with Europe's ingrained, distrustful politics. (26)

"Progressive" is a key word here because Progressive thought remained an important influence during this period and contributed to the American admiration for Mussolini, as well as support of the Weimar Republic in Germany. Mussolini, as we have already seen, was frequently compared to that consummate progressive, Theodore Roosevelt. Journalist Edgar Ansel Mowrer, a man with serious doubts about Fascism (and later a leading opponent of the Nazis), nevertheless refused to dub Mussolini a reactionary, describing his regime as "a kind of Tory democracy or benevolent Rooseveltian idea of prosperous masses, individualism, militarism and a strong state all

harmonized." (27) The overwhelming view seemed to be that whatever its imperfections, Mussolini's Fascist Italy was a nation that could and should be conciliated. The Americans 
also worked to keep the Italian-American relationship on a favorable footing.

Thanks to the careful efforts of Mussolini, Margherita Sarfatti and other leading Fascists, the regime's control of American correspondents was unprecedented. The three leading journalists for American newspapers in Rome all became eventual agents of the regime. While many of the foreign correspondents in Rome were "police spies and hacks," these reporters were men of considerable reputation: Salvatore Cortesi of the Associated Press; Arnaldo Cortesi (his son) of the New York Times, and Thomas B. Morgan, the head of the Rome Bureau of the United Press. Morgan became the "compulsory point of contact" for any American besides diplomats who wished to meet with Mussolini.

Sarfatti herself edited a series of articles for Mussolini that appeared in the newspapers of William Randolph Hearst's American newspaper chain from 1931 to 1933. Although Hearst considered Fascism unsuited to American values, he far preferred Fascism to Bolshevism, which he saw as the only other likely alternative in Europe. Hearst maintained close relations with British Fascists and was even one of the most dedicated American admirers of Hitler until well into the 1930s. (30) The articles in the Hearst press gave Mussolini a direct access to a Sunday circulation of $5.7 \mathrm{million}$ in an American 
population of about 124 million in 1931, and may have reached up to one third of adult Americans. (31)

Fascism's detractors sometimes found it hard to dispute its impressive achievements. Nicholas Murray Butler, President of Columbia University and a leading figure in the Republican party, saw Fascism as the strongest and most alarming challenger to liberal democracy, but could not deny "the stupendous improvement which Fascism has brought in the order, the safety, the health, the education, the comfort, and the satisfaction of the Italian people." Describing the postwar "anarchy" in Italy, as had other writers, he noted an alarming trend: . . anarchy, bankruptcy, moral powerlessness, had apparently seized upon that great people. They attributed it to their imitation of our institutions, to our philosophy of life and of government. Our English and French and American democracy was held responsible by them for their own downfall, and they set about remedying it in most extraordinary fashion.

After Butler's 1927 speech praising Mussolini, he received an invitation to meet with the Duce in Rome to discuss his views. After meeting with Mussolini, Butler became an enthusiastic friend and supporter though he retained internationalist values that conflicted with those of the Italian leader. Mussolini gave strong support to the Casa Italiana, Columbia's newly opened institute for the study of Italian culture, and Butler's friendship with Mussolini and later Margherita Sarfatti provided the 
Italian leaders with introductions to many members of America's highest political and diplomatic circles.

Breckinridge Long, Roosevelt's ambassador to Rome after 1933, also became a close associate of Mussolini and Sarfatti. Long became a fan of the regime despite its secret police, controlled press, and the constant espionage he had to tolerate at the embassy. He and Alexander Ring, the charge d'affaires in Rome, both became close associates of Sarfatti. (34) When Sarfatti made her first trip to the United States in 1934, she was received as an unofficial consort of Mussolini and carried letters of introduction from Ambassador Long to present to President Roosevelt, Secretary of State Cordell Hull, Undersecretary of State William Phillips, and other leading Washington figures.

Roosevelt and Mussolini had begun secret contacts in late 1932, and Mussolini hoped for a special relationship with the newly elected President. He even had hopes that Roosevelt would follow the example of Mussolini's "corporate state" -- and indeed, some of Roosevelt's detractors felt that he did so in creating the New Deal. (36) The Depression had intensified in 1932, and some Americans began searching for an alternative that would spare them the vicissitudes of unbridled capitalism without succumbing to the brutal excesses of Communism. To many, Mussolini's corporate state seemed to offer that 
example -- a collection of state-run groups of owners, managers and workers that could control the economy, mediate disputes, and give the nation a centrally planned economy. (37)

As the Depression raised questions about traditional free-market capitalism, it also led many to question traditional representative politics. Was Anglo-Saxon style liberal democracy outmoded? Throughout the twenties, leading American liberals such as Walter Lippmann, Herbert Croly and Charles Beard had concluded that democracy was unworkable even in America, and H.L. Mencken had condescendingly poked fun at the nativism and Prohibitionism that characterized American-style "majority rule." A contempt for democracy was fashionable among many American intellectuals, such as Irving Babbitt, who decried universal suffrage and suggested America might need its own Mussolini to save itself from the equivalent of a Lenin. Suggestions of this kind multiplied alarmingly among conservatives as the Depression intensified in 1932 , and by 1934 former president Hoover was writing an alarmed defense of old-fashioned American liberalism, which he saw assailed everywhere by the "regimentation" of Communism, Fascism, Nazism and the New Deal.

In the midst of postwar disillusionment and the Depression, many had decided that new, different types of governments --including Fascist dictatorships --might be 
right for some nations. As Emil Ludwig noted in the

Introduction to his Talks Hith Mussolini, one reason he had changed his opinion on Mussolini to a favorable one was the evidence that "the foundations of 'democracy' and "parliamentarism are crumbling."

Mussolini's Fascist state, despite its positive aspects, was nevertheless widely known as a dictatorship that suppressed vital freedoms and condoned political murder. Herbert Hoover observed in hindsight that Italian Fascism, while it "was attracting more public attention than Communism . . it was equally a despotism with a police state wholly denying most freedoms." As Fascism was known to have many of the same repressive characteristics Americans criticized in Bolshevik Russia, it is worthwhile to ask why the American government and public's initial reaction to Mussolini was not more unfavorable. This question and its answer were summarized well by British political commentator Harold Laski in 1923:

The historian of the next generation cannot fail to be impressed by the different reception accorded to the changes of which Lenin and Mussolini have been the chief authors. Where Lenin's system has won for itself international ostracism and armed intervention, that of Mussolini has been the subject of widespread enthusiasm. He himself has been decorated by the governments of foreign powers; ambassadors have exhausted the language of eulogy at official banquets; and great men of business have not hesitated to say that only the emulation of his methods can reduce the working classes to a proper state of mind. Yet, save 
in intensity, there has been no difference in the method pursued by the two men; and it is difficult to avoid the conclusion that the different reception of their effort is the outcome of their antithetic attitudes to property. (40)

Under Fascism, as Ambassador Child had noted, there was no abolition of capital or private enterprise, and class war and state ownership were vigorously opposed. The Fascist corporate state, with its producers ${ }^{\circ}$ and consumers cooperatives organizing all industries and labor, did not pose a threat to capitalism. Child equated these organizations and their expert leadership councils with some of the measures instituted to create governmentbusiness cooperation in the United States during World War I. This sort of "expert" leadership and businessgovernment cooperation held a certain appeal for Child and others who wanted to keep America on the track of prosperity.

Mussolini's propaganda efforts in America paid off admirably. In 1925, Italian and American representatives agreed to settle Italy's World War I debt on terms that favored Rome, and the British soon followed suit. The Morgan Bank lent Mussolini's government $\$ 100$ million shortly afterward, and other American loans over the next two years totaled $\$ 140$ million to help build Italy's infrastructure.

American investment in Italy increased over the course 
of the decade, with direct investment in Italian utilities exceeding $\$ 66$ million by 1930 , and American loans reaching $\$ 462$ million. Major American companies such as United States Steel, General Electric, Bankers Trust Company, and the Mellon interests hastened to Italy to take advantage of the opportunities Mussolini offered, and the improved relationship motivated Secretary of Commerce Herbert Hoover to suggest that "a man of large industrial, financial and commercial vision" be appointed to help protect these interests. (43)

The friendly relationship between Italy and the United States continued well into the 1930 s despite Italy's desire to "have its place in the sun." (44) It even weathered the assiduous efforts of the American "highbrow" press to publicize Mussolini's involvement with American Fascist organizations and the impressment of Italian-American U.S. citizens visiting Italy.

Mussolini disavowed the activities of Fascists abroad, particularly when they said or did anything offensive to the Americans. As the ostensible creator of Fascism and its doctrines, Il Duce was in a position to decry activities as not being reflective of "true" Fascism, and he did this frequently. The Italian Ambassadors to the United States, Gelasio Caetani and his successor Giacomo de Martino, were often the mouthpieces for these assertions. Mussolini had not purged the government of all its 
former functionaries, and Caetani and de Martino represented a class of career diplomats who "had agreed to serve Mussolini in the hope of curbing Fascism's inflated ambitions abroad . . ." Before the Mussolini-Hearst

alliance took hold, Caetani had seen the early unflattering portrayal of Italian-American Fascist groups (fasci) in the Hearst press, where they were presented as "haunts of criminal and subversive elements." He wanted to curb their activities to prevent further discrimination against Italian immigrants and possible problems in funding Italy's war debt to the United States. However, these efforts were opposed from within by Fascist party enthusiasts in Italy and America, leading to "smoldering hostility between a cautious bureaucratic class and the exuberant party zealots. . ." (46)

The balance tipped in favor of the zealots in 1925, when Mussolini imposed full dictatorship and settled the war debt with the United States. There was no longer as much reason to fear America's reaction to Fascist agitation within its borders. Count Ignazio Thaon di Revel came to America to unite the different fasci into the Fascist League, and openly admitted he was an authorized representative of the Italian government.

In the early years of Fascism, Washington had had some misgivings about the Fascist organizations, but de Martino, the second of the ambassadors, received little support for 
his offers to curb their activities. In the Departments of State, Justice and Labor, the sporadic violence of these groups was excused because of their apparent antiBolshevism and support for law and order. (47)

In 1927, when discussions arose over the activities of Fascist organizations within the United States, de Martino insisted that "Mr. Mussolini was very angry at many of the things that were happening and said that many of the Fascists were acting as fools" by marching in uniform and performing other activities he insisted were beyond the control and "absolutely contrary to the advice of the [Italian] Government." However, the evidence clearly shows that Mussolini was behind the organization and maintenance of the American fascist groups from the beginning.

In February 1928, the American Embassy in Rome expressed concern over some new "commandments of the Duce" bearing Mussolini's signature and clearly expressing his desire to extend his rule as absolute law to Fascist organizations abroad, including those in the United States. De Martino moved quickly to explain that he had urged Mussolini "on account of special conditions in the United States, to make those orders not applicable in this country." He also noted that many of these Leagues were composed of "cranks" whose activities could give Italy a bad name by association, but since they were made up 
largely of American citizens, they could not be controlled effectively from Rome.

(49)

The Secretary of State seconded this position in response to an inquiry from Representative Hamilton Fish, $\mathrm{Jr}$. regarding American Fascist activities. (50) In November 1929, Marcus Duffield's article in Harper's, "Mussolini's American Empire," had accused the Fascist groups of harassing Italian-Americans and impeding their naturalization as American citizens. Although a State Department inguiry proved much of Duffield's evidence to be inaccurate (a fact he admitted), Mussolini disbanded the Fascist League in the United States. To soften the blow, the Secretary of State issued a statement to the press noting that his department's investigation had revealed no activities against the United States government on the part of Italian officials or American residents of Italian extraction. The Secretary's statement continued:

So far as the dissolution of the Fascist League is concerned, inasmuch as the existence and purpose of that League have been the subject of adverse speculative comment and possible misunderstanding, I am glad to express my appreciation that the League has dissolved itself in the interest of removing those misunderstandings and better relations between this country and Italy. (51)

This incident demonstrates Mussolini's efforts to stay in good favor with the American government and public. Admittedly, the efforts of Mussolini's diplomats to control his overreaching kept this incident from growing into 
something far more troublesome. However, this was also due to the American government's efforts to conciliate Mussolini, even when questions arose of his possible meddling with the lives of Italian immigrants on American soil.

Throughout the 1920s and into the 1930s, Mussolini insisted that Fascism was not a product for export, although this was only said to reassure foreigners. In reality, the Fascist government spent an enormous amount on propaganda, arms smuggling, and organizations abroad. When asked by Emil Ludwig in 1932 whether Fascism could be exported to Germany, Mussolini answered that it was a purely Italian creation, although some of its ideas could be adapted to German conditions. (53) When the Nazis became prominent in German politics in the early thirties, the Italians made a concerted effort to dissociate themselves from the Hitler movement's objectionable activities. Mussolini was greatly helped in his efforts by Dino Grandi, his Foreign Minister from 1929 to 1932.

Grandi was a dedicated Fascist whose "energy, charm, and persistence" served to conciliate the United States as well as Great Britain, where he went as Ambassador in 1932 after Mussolini forced him out and decided to serve as his own Foreign Minister. He visited the United States in 1931 and had a cordial visit with Undersecretary of State Castle, who noted how "sensibly" he discussed European affairs. 
Grandi applauded American efforts to take the lead in matters such as the international debt crisis. He also "took occasion to say that it annoyed the regime in Italy to have the Hitlerites call themselves fascists as they had nothing in common with fascism."

At the end of Grandi's visit, he and Secretary of State Stimson issued a joint statement emphasizing "the restoration of economic stability" and lauding Grandi's proposal for a one-year armaments truce, all at a time when Hitler's Nazis were making themselves a watchword for destructiveness and destabilization in Germany. The contrast could not have been more pronounced, and the words of Secretary Stimson in his memoirs bear repeating --in 1931 and 1932, the Italians appeared to be "the least difficult" of the Continental powers.

Mussolini's dependability continued through 1934, when Hitler made his first attempt at annexing Austria by attacking the government of Chancellor Engelbert Dollfuss. Mussolini intervened to prevent this attempted Nazi aggression, and as an apparent peacekeeper his popularity in Europe and the United States reached an all-time peak. He scored points again with American diplomats, one of whom observed:

$$
\begin{aligned}
& \text { despite Mussolini's sympathy for Fascism } \\
& \text { in the Reich, the Duce is a hard-boiled realist } \\
& \text { and must of necessity exert every possible } \\
& \text { effort to prevent Germany sextending its } \\
& \text { frontier southward to the Brenner Pass. }
\end{aligned}
$$


Germany today is not unlike a crazy man wildly brandishing a revolver. (56)

Again, Mussolini disavowed Hitler and the more repellent features his regime displayed now that he had attained power:

M. de Chambrun [the French Ambassador to Austria] said that Mussolini told him that Hitler was a disciple of Fascism who did not play the game according to the rules, meaning that Mussolini disapproves of persecutions of Jews and other features of the Nazi program. The French Ambassador also guoted Mussolini as saying that Hitler has less real power than is generally supposed and that there are some movements in Germany which he cannot control. (57)

This last statement of Mussolini's, of course, would prove over time to be incorrect. Hitler consolidated his power with an alarming swiftness, and in fact had largely silenced all other parties by August 1933, when Mussolini made this statement. Hitler took control of German society in a way Mussolini had never been able to do in Italy, where the church and the monarchy still held considerable power, and political opponents had kept him from solidifying his control until after the murder of Matteotti in 1924. Mussolini was the architect of Fascism, the man who had defined the movement and set down its doctrines, though he did so largely after its actual creation. (58) In 1933 he was still the senior member of what one American diplomat called the "community of interest between the two now Fascist nations." 
Hitler's expansionistic tendencies were averted in 1934 but would later triumph throughout Europe, and Mussolini soon found himself forced into the role of junior partner in an alliance with Hitler. (60) By 1936, Mussolini, who had previously stressed the differences between Nazism and Fascism, began to describe the two ideologies as German and Italian variants of the same program. He also began to consider Hitler's offer of an Italo-German alliance against Bolshevik Russia and the West. (61) Mussolini did act as a dictator within his own borders, but until the time of the Ethiopian invasion and his later alliance with Hitler, he was willing to carry out foreign policy within the confines of the international system, making him an acceptable ally to the Americans and other European nations.

Hitler, however, had taken elements of Fascism and submerged them into a new "outlaw" ideology that not only disrespected the rights of its citizens but flouted the rules governing international conduct. Even before attaining power, Hitler had made his views clear, and he did not change after taking over Germany. His seeming disregard for international opinion and financial stability often caused American and British diplomats in Germany to view Nazism not as a more extreme variant of Italian Fascism, but as an ideology more akin to the "outlaw" regime of the time--Soviet Russia. 
ENDNOTES

(1) Costigliola, Awkward Dominion, 93-94.

(2) Ibid., 94. $52-54$.

(3) Denis Mack Smith, Mussolini (New York, 1982),

(4) Ibid., 41, 47, 55; Philip V. Cannistraro and Brian R. Sullivan, Il Duce's Other Woman (New York, 1993), 229-232. $231-232$.

(5) Cannistraro and Sullivan, Il Duce's Other Woman,

(6) Mack Smith, Mussolini, 171.

(7) Child to State (Telegram/paraphrased), November 3 , 1922, 711.65/10, Reel 1, National Archives Microfilm Publications \#529, Records of the Department of State Relating to Rolitical Relations Between the United States and Italy, 1910-29.

(8) Benito Mussolini, My Autobiography (New York, 1928), 69. For spirited denunciations of Mussolini's alleged role as the savior of Italy from Bolshevism, see the following works by Italy's leading exile historian of the Fascist period, Gaetano Salvemini: Under the Axe of Eascism (New York, 1969), 144-158, and The Eascist Dictatorship in Italy (n.c., 1927; reprint ed., New York, 1967), 3-54 passim.

(9) See H. Nelson Gay, Strenuous Italy (Boston, 1927), 165, for more claims about Mussolini's saving Italy from Bolshevism. The American ambassador in London is quoted in Costigliola, Awkward Dominion, 94; Undersecretary Castle's comments are from Hilliam Castle to Henry Fletcher, June 15, 1926, Container 13, Henry P. Fletcher Papers, Library of Congress, cited in John P. Diggins, Mussolini and Eascism: The View Erom America (Princeton, $1972), 29$.

(10) Costigliola, Awkward Dominion, 94. Child to State (Telegram/paraphrased), November 3, 1992, 711.65/10, National Archives Microfilm Publications \#529, Records of 
the Department of State Relating to Rolitical Relations Between the United States and Italy, 1910-29.

(11) Gunther to State, December 2, 1922, ERUS 1922 $2: 589$. This friendliness was expressed through conciliatory diplomacy and unctuous flattery such as the following, from a speech Mussolini made for American consumption in 1927 after disputes arose regarding the activities of the Fascist League in the United States:

An intelligent and alert Ambassador like His Excellency Mr. Fletcher easily notices every phase in the development of international friendship. His perception must already have convinced him of the constant sympathy and sincere admiration felt by all Italians for his country.

I also desire to pay tribute to $\mathrm{Mr}$. Fletcher for having brought about this warmth of feeling. He is a symbol to Italy of the Starry Republic. He has kept alive in our hearts that warm feeling of friendship. (Translation of speech from "Giovinezza," Official Bulletin of the Fascist League of North America, for October 1, 1927, enclosure with Fletcher to State, October 24, 1927, ERUS 1927, 3:127.)

(12) Mack Smith, Mussolini, 59, 94; Alan Cassels, "Mussolini and German Nationalism, 1922-25," Journal of Modern History 35:2 (June 1963), 137-138. Also see Cassels" article, "Fascism for Export: Italy and the United States in the Twenties," American Historical Review 69:3 (April 1964), 707-712.

(13) John P. Diggins, Uussolini and Eascism, 29; Henry L. Stimson and McGeorge Bundy, On Active Service in Beace and Har (New York, 1947), 269, 270.

(14) See Diggins, Musselini and Eascism, 25-26 for a breakdown of how different types of periodicals interpreted Mussolini's regime. The following are a few articles representative of the anti-Mussolini journalism of the 1920 s and the objections to Fascism described in the text: James Fuchs, "Why Matteotti Had to Die," The Nation, 119:3082 (July 30, 1924), 114-115; Oswald Garrison Villard, "Mussolini and the Klan," The Nation 119:3078 (July 2, 1924), 5; Marcus Duffield, "Mussolini's American Empire: The Eascist Invasion of the United States," Harper's Masazine 159 (November 1929), 661-672; Hiram Motherwell, "Mussolini: Emperor of the Latins?" Harper's Hasazine 159 
(June 1929, 34-44. Harold Laski, "Lenin and Mussolini," Eoreign Affairs 2:1 (September 1923), 43-54, draws parallels between Russian and Italian varieties of dictatorship and questions the American daily press's largely laudatory treatment of Mussolini. Literary Diesest, a leading periodical of the time, showed an attitude of alarm toward Mussolini while treating him as the subject of humor: see Anon., "Mussolini's Road to Imperial Italy," Literary Digest, June 9, 1923, 18-19 and Anon., "Why Mussolini Charms the American Business Man," ibid., 72-74. An angry contemporary account of Mussolini's repressive regime is George Seldes, You Can't Print That! The Truth Behind The News 1918-1928 (New York, 1929), 69-148 passim. Seldes was an American muckraker expelled from Italy in 1925 for his unflattering reports on Mussolini. The details of his expulsion can be found in ERUS 1925, 2:363366 .

(15) Joan Hoff Wilson, American Business \& Eoreign Policy (Lexington, Ky., 1971), xiv. Pierson's remarks appeared in Anon., "Why Mussolini Charms the American Business Man," Literary Digest, June 9, 1923, 73. For further information on American business reaction to Mussolini see James Warren Prothro, The Dollar Decade: Business Ideas in the 1920's (Baton Rouge, 1954), 204-206; Diggins, Mussolini and Eascism, 146-48, 159-66, 297-99. It is notable that business support for Mussolini in some quarters continued even after the Italian invasion of Ethiopia, with many American businessmen ignoring President Roosevelt's "moral embargo" of Italy. See Roland Stromberg, "American Business and the Approach of War, 1935-1941," Journal of Economic History 13:1 (Winter 1953), $64-65$.

(16) Diggins, Mussolini and Eascism, 5; Herbert Hoover, The Challenge to Liberty (New York, 1934), 71; Edgar Ansel Mowrer, "The Fascisti and Italy's Economic Recovery," The Eorum, 69:1 (January 1923), 1199, 1200. For more on American views of Italian "national character," see William L. Vance, America's Rome: Volume II, Catholic and Contemporary Rome (New Haven, 1989), 296. The AngloAmerican tendency to see Fascism as a result of "national character" was criticized as "lazy thinking" by Italian historian Gaetano Salvemini, see Adrian Lyttelton, "Italian Fascism," in Walter Laqueur, ed., Eascism: A Reader's Guide (Berkeley, 1976), 126.

(17) Richard Washburn Child, "Foreword," in Benito Mussolini, My Autobiography (New York, 1928), ix-xix. For a contemporary observer's view of Mussolini's assiduous courting of the American and British diplomatic corps, and 
of Child's infatuation with the Fascist leader, see Lilian T. Mowrer, Journalist's Wife (New York, 1937), 174-175.

(18) Richard Washburn Child, A Diplomat Looks at Europe (New York, 1925), 208, 202, 153, 155.

(19) H. Nelson Gay, Strenuous Italy: Solving a Perilous Problem (Boston, 1927), Preface, 113. For a full exploration of Fascism's appeal to American pragmatists, see John P. Diggins, "Flirtation With Fascism: American Pragmatic Liberals and Mussolini's Italy," American Historical Review 71:2 (January 1966), 487-506.

(20) Robert $\mathrm{H}$. Wiebe, The Search Eor Order, 160, 154$55,189-90$.

(21) Cannistraro and Sullivan, Il Duce's Dther Woman, $299-300,303$.

(22) James R. McGovern, "David Graham Phillips and the Virility Impulse of Progressives, "The New England Quarterly 39:3 (September 1966), 325-6; Wiebe, The Search for Order, 229-235.

(23) Denis Mack Smith, Mussolini's Roman Empire (New York, 1976), viii.

(24) Heald, Transatlantic Vistas, 229, 116-7, 104. Heald's book is a rich source of information about the adventures and problems of American correspondents in Fascist Italy, Weimar Germany, and early Nazi Germany.

(25) Mack Smith, Mussolini's Roman Empire, 10-11.

(26) Heald, Transatlantic Vistas, 84.

(27) Mowrer is quoted in ibid., 86-7.

(28) For an example of American efforts to maintain good relations with Fascist Italy, see ERUS 1927 3:119-125, which recounts the efforts of Italian aviator Commander $\mathrm{De}$ Pinedo to demonstrate an Italian Navy hydroplane at Roosevelt Dam, Arizona. The first hydroplane was destroyed in an accident, causing Italy's Fascist press to react with alarm about a possible anti-Fascist plot. A carelessly dropped match proved to be the cause of the accident, and De Pinedo eventually completed his mission with another hydroplane sent from Italy. However, the Americans approached Mussolini with the utmost flattery and caution regarding the incident. See Fletcher to State, April 8, 1927, ERUS $19273: 120$. 
$351-2$.

(29) Cannistraro and Sullivan, Il Duce's Other Homan,

(30) Ibid., 360-362.

(31) Ibid., 362 .

(32) Nicholas Murray Butler, "New Critics of

Democracy," address given at the University of Virginia, April 13, 1927, in Looking Forward: What Will the American People Do About It? Essays and Addresses on Matters National and International (New York, 1932), 191. $401-2$.

(33) Cannistraro and Sullivan, Il Duce's Other Woman,

(34) Ibid., 408-9, 400.

(35) Ibid., 422, 430-1.

(36) See Hoover, The Challenge to Liberty, 76-137, in which he attacks "National Regimentation" (i.e., the early New Deal) as one of the problematic alternatives to traditional American liberalism. The others, of course, were Communism, Socialism, Fascism and Nazism. $402-404$.

(37) Cannistraro and Sullivan, Il Duce's Other Woman,

(38) John P. Diggins, The Rise and Eall of the American Left (New York, 1992), 141; Arthur M. Schlesinger, Jr., The Crisis of the 0ld Order. 1919-1933 (Boston, 1957), 148-149, 268; Hoover, The Challenge te Liberty, passin.

(39) Emil Ludwig, Talks With Mussolini, trans. Eden and Cedar Paul (Boston, 1933), 4; see also Theodor Eschenburg, "The Collapse of Democratic Regimes Between the First and Second World Wars," in Lawrence Wilson, trans., The Road to Dictatorship: Germany 1918-1933 (London, 1964), 18-19. This essay is an interesting exploration of the failures of many "improvised" democratic regimes imposed in Europe by the World War I victor powers.

(40) Herbert Hoover, The Memoirs of Herbert Hoover, Volume II, The Cabinet and the Presidency, 1920-1933 (New York, 1952), 331; Harold Iaski, "Lenin and Mussolini," Eoreign Affairs 2:1 (September 1923), 52-53. For more information on Lenin/Mussolini parallels, see Gardiner, Rortraits and Rertents, 92-93. 
(41) Child, A Diplomat Looks at Europe, 216-217.

354 .

(42) Cannistraro and Sullivan, Il Duce's Other Woman,

(43) Costigliola, Awkward Dominion, 94.

(44) Memorandum by Assistant Secretary of State Castle of a Conversation with the Italian Ambassador (Martino), February 10, 1928, ERUS 1928 3:109.

(45) Two important articles denouncing Mussolini appeared in Harper's during 1929: Hiram Motherwell's "Mussolini: Emperor of the Latins?" in June and "Mussolini's American Empire: The Fascist Invasion of the United States," by Marcus Duffield, in November (see footnote \#14 above).

(46) Alan Cassels, "Fascism For Export: Italy and the United States in the Twenties," American Historical Review 59:3 (April 1964), 708, 709.

(47) Ibid., 709, 710.

(48) William Castle, Memorandum of conversation with Martino, November 26, 1927, ERUS 1927, 3:128; Cassels, "Fascism For Export," 711.

(49) Robbins to State, February 9, 1928, ERUS 1928, $3: 107$, 108; Castle memorandum of conversation with Martino, February 10, 1928, Ibid., 109.

(50) Frank Kellogg (Secretary of State) to Representative Hamilton Fish, Jr., March 3, 1928, ERUS $1928,3: 111$.

(51) Cassels, "Fascism For Export," 711. The decision to dissolve the Fascist League was announced in December 1929, after Marcus Duffield's article, "Mussolini's American Empire" had appeared in the November Harper's. See "Memorandum by the Secretary of State of a Conversation with the Italian Ambassador (De Martino)," December 5, 1929, ERUS 1928, 3:111 and "Statement Issued to the Press by the Secretary of State," December 27, 1929, Ibid., 112 .

(52) Mack Smith, Mussolini's Roman Empire, 10-11, 24.

(53) Ludwig, Talks With Mussolini, 162. 
(54) "Memorandum by the Under Secretary of State (Castle) of a Conversation with the Italian Minister for Foreign Affairs (Grandi), November 16, 1931," ERUS 1931, $2: 646,648,647$. The characterization of Grandi is from F.W. Deakin, The Brutal Eriendshio: Mussolini. Hitler and the Eall of Italian Eascism (New York, 1962), 46.

(55) "Joint Statement by the Italian Minister for Foreign Affairs (Grandi) and the Secretary of State," November 19, 1931, ERUS 1931, 2:648; Stimson and Bundy, on Active Service, 269 .

(56) The Minister in Austria (Stockton) to State, August 19, 1933, ERUS 1933, 1:434-435.

(57) The Ambassador in Italy (Breckinridge Long) to State, August 24, 1933, ERUS 1933, 1:438. $197-8$.

(58) Cannistraro and Sullivan, Il Duce's Other Woman,

(59) The Charge in Germany (Gordon) to the Acting Secretary of State, May 12, 1933, ERUS 1933, 1:427.

(60) For a full-fledged study of the changing HitlerMussolini relationship, beginning with 1936 when Mussolini had already become the junior partner, see Deakin, The Brutal Eriendship. $488-9$.

(61) Cannistraro and Sullivan, Il Duce's Other Woman, 
CHAPTER IV

THE AMERICANS AND WEIMAR GERMANY - THE 1920'S

During the interwar period, American business and financial interests became truly multinational, extending themselves throughout Europe but most of all in Germany. The postwar American dominance in Europe required peace and prosperity in all European nations, but most of all it depended upon the stability of a new and precarious political entity -- the Weimar Republic.

The Weimar Republic began as a "makeshift democracy," improvised as an "emergency solution" to the problems of defeat in World War I. No long-standing tradition of republican government existed in Germany, although at the end of the war Reichstag leaders were working to strengthen the democratic element under the empire. The republic had been created largely to appease the World War I victor nations and particularly Woodrow Wilson, who demanded an end to the monarchy. Field Marshal Paul von Hindenburg and General Erich Ludendorff, who had run the government as a de facto military dictatorship in the last years of the war, stepped aside and thus avoided for the loss of the war. The stigma of the loss was transferred to the new republic. When the victorious Allies imposed a harsh peace 
despite the Kaiser's abdication, the origins and aims of the republic seemed even more tainted. The result was a complicated political structure that was shaky from the beginning.

The Weimar system had a proportionally elected legislature, the Reichstag, which gave each party a representative for every 60,000 votes received. While this configuration gave equal weight to each vote, it left the electorate "with the task of voting not persons but rather parties into power." (3) And Weimar Germany had political parties in profusion, representing every imaginable point on the political spectrum. These parties ranged from the Communists (KPD), the most radical of the leftist parties, to the leftist/liberal Social Democrats (SPD), to the liberal German Democratic Party, the Catholic Centre and the Bavarian People's Party to the far right parties - the Nationalist Party (DNVP) led by publishing magnate Alfred Hugenberg, and eventually the National Socialist German Workers' Party (NSDAP), better known as the Nazis. Along with these major parties, there were numerous other splinter parties built around all manner of constituencies. Since no party could achieve a simple majority, the worst problem of the Reichstag was the inability of the major parties to form and sustain coalitions, particularly in the last chaotic years of the Republic.

German party politicians were more committed to their 
own partisan ends than to the success of the republic itself, and many lacked an interest in the compromises required to make the government work. Sizable contingents of extremists in the Reichstag, on both the left and the right, did not want the system to work. These extremists included the Hugenberg Nationalists, the Communists, and in later years the Nazis. They were anything but a loyal opposition, and they worked constantly to destroy parliamentary democracy or disrupt its workings. Even the parties that wanted to maintain the Republic did not have real experience within a parliamentary framework. The heated interparty squabbling of Weimar politics was a legacy from the imperial past, in which the parties had been excluded from power and therefore had not been obliged to compromise and create viable governments. One of the most notable offenders in this was the Social Democratic Party (SPD), the largest party in the Reichstag throughout most of the Republic's existence. The Social Democrats shrank from compromises for fear of taking responsibility for any possible failures or unpopular actions. Without the cooperation of the largest party, the parliamentary system was in danger from the start.

There were other problematic aspects of the Weimar Constitution. The Constitution provided for the popular election of a Reichspresident to represent Germany abroad, appoint the Chancellor as head of government, and be 
commander-in-chief of the armed forces. He also had the power to dissolve the Reichstag and to enact law by decree under Article 48 of the Constitution, though these emergency decrees required the approval of the Reichstag.

(6) The use of the Article 48 emergency powers became most important in the last months in power of Chancellor Heinrich Brüning. Faced with a hopelessly fragmented Reichstag, he carried the country through 1931 and 1932 using the emergency decree powers, thus paving the way for their later use by the Nazis when Hitler took over as Chancellor in 1933.

In the early 1920s, however, the worst dangers of Weimar democracy had not yet surfaced. Moreover, Germany's move to a republican form of government had helped change the American attitude toward the nation. The Germans, formerly cast as villains in a deluge of World War I propaganda, were now represented as decent, hardworking people who had been led into evil by their leaders, Kaiser Wilhelm II, Hindenburg and Ludendorff. In his 1920 message to Congress, President Wilson declared that the Germans had learned their lesson:

You will remember that the beginning of the end of the war came when the German people found themselves face to face with the conscience of the world and realized that right was everywhere arrayed against the wrong that their government was attempting to perpetrate. (7)

In the struggle to protect the republic against its 
enemies of both political extremes, the Americans understood their position, which was that of stabilizing the existing regime with economic relief. The American Commissioner warned in 1920 that there would be extreme disapproval of any attempt

from whatever side to interfere with orderly and stable conditions. Acts of violence and endeavors to revolutionize the Government by unconstitutional methods will not fail to imperil the reestablishment of good relations with the United States. Such actions will also seriously interfere with the readjustment of Germany and the amelioration of the present unfavorable economic conditions by the measures of relief which have been projected and already initiated.

The Americans were aware that by controlling the flow of money and necessary goods to Germany, they held considerable power over the republic's present and future. The financial element was the key to the maintenance of German democracy. In the words of Owen D. Young, Chairman of the Board of General Electric and later chairman of the committee that created the Young Plan for reparations revision, "you can not make progress toward high ideals until you get your money matters straightened out first." (9) Yet as the United States poured money into Germany, American business and bankers became ever more dependent upon the return of the monies invested, and thus more vulnerable should the republic fail or be endangered.

The instability of the republic led to fears of possible debt repudiation by the Germans. The Americans 
and British had already taken heavy losses because of the repudiation following the Russian Revolution, and these fears surfaced in the creation of the treaty of friendship between the United States and Germany in December 1923, which came on the heels of the notorious German inflation of that year. The Americans demanded and got a provision that the property of their nationals "not be taken without due process of law and without the payment of just compensation." There had been some discussion with the Germans over this provision, since the Weimar Constitution permitted the taking of property without compensation. In this case, however, given the fears and demands of the Americans, an exception was made.

As the leading creditor in the world, the United States was able to dictate policy to some extent. The U.S. was at the center of the reparations cycle in which Germany paid to compensate the Western Allies for the costs of World War I. This money was channeled by the Allies to the United States to pay back war debts to the Americans. The American banks completed the circularity by lending money to the Germans to help strengthen their economic base. Official American policy "admitted no direct connection between war debts and reparations" until the entire system began to fall apart in the early 1930s, but the United States always had a vital role in keeping the cycle moving, and in keeping Weimar Germany solvent. 
When the German economy began to crumble in 1922, at least partly because of the reparations burden, the solution was apparent, given the financial position of the United States among the major nations:

A new, less stringent agreement tied to an American loan to Germany was needed but this depended on the debt settlement: Britain owed the United States; France and the other allies owed Britain; and Germany owed France and the Allies." (12)

An agreement was finally hammered out with the help of Stanley Baldwin, then British Chancellor of the Exchequer. France occupied the Ruhr in 1923 in retaliation for German nonpayment of reparations, and this spurred on the negotiations. In April 1924, a plan was created by an international committee headed by American financier Charles Dawes, a "new reparations scheme to take the pressure off Germany." President Coolidge praised the Dawes Plan, insisting that reparation adjustment was "not a political but a business problem," though State Department Financial Advisor Herbert Feis was perhaps more accurate in later years when he described the war debts as "sludge left after the fires of the First World War had died down." (13) The Dawes Plan did take the pressure off a while, but in 1929 the Americans were forced to step in with another plan for loans and revisions of reparations --the Young Plan, named for Owen D. Young of General Electric, who chaired the international committee that created the plan. 
The Young Plan was highly controversial in Germany, and the Nazis, Nationalists and Communists gained considerable publicity and numerous adherents by opposing it.

Many have insisted that the Weimar leaders were themselves responsible for their nation's financial problems, and some have even accused them of engineering the disastrous inflation of 1923 , but these leaders still represented the kind of stable republican government the United States wanted to see in Germany. In keeping with American policy of the times, Weimar was stabilized not through political means but with American money. Between 1924 and 1929, American banks made major loans to German governments at all levels, from local to national. American money also rebuilt many sectors of German industry, and the American public bought nearly $\$ 1.5$ billion in German stocks and bonds. Reparations were received as planned, but only because of the enormous influx of foreign, and particularly American, funds. Between 1924 and 1929, Germany borrowed approximately 13.5 thousand million reichsmarks, while her reparation obligations were only 8.5 thousand million reichsmarks. (14) In 1925 and 1926, the American Embassy in Berlin and S. Parker Gilbert, the American Agent General for Reparations, began to express open alarm regarding the extent of American loans and investments in Germany, an alarm that would later be echoed in other quarters. 
However, American investment in Germany continued largely unabated until the Depression struck both nations.

What the Americans feared most was the resurgence of any kind of extremist politics that could threaten the investment climate. Some of their worst fears would subsequently be justified in the late 1920 s and early 1930s by the Nazi, Communist and Nationalist activity against the Young Plan.

Weimar Germany was rife with political and financial crises, including the abortive right-wing Kapp Putsch of 1920, the French occupation of the Ruhr, and the subsequent hyperinflation of 1922-23. Despite the constant problems and disorder, many Americans held an image of the Germans as an orderly, peaceful people who only needed a chance to reorder their nation and put representative government to work. John Foster Dulles, even while observing the unrest of the Kapp Putsch and the Communist revolt in the Ruhr in 1920, marveled at the essential German orderliness and respect for property. As Edgar Ansel Mowrer observed in 1928 of the "revolution" that created the Republic, It was essentially the act of a people that instinctively and by education prefers "quiet and order" to political freedom and the right to play the piano after ten P.M. . . . It was a German revolution, a respectable, orderly, self-controlled, decent, middle-class revolution. (16)

American support for the Weimar Republic was strongly colored by the perception that a parliamentary, republican 
form of government should be able to succeed in Germany.

Jacob Gould Schurman, the American Ambassador to Germany, made an optimistic declaration in 1927 that the two nations were both true democracies:

Never in our history have the political institutions and international ideas of Germany and the United States been so much in agreement as they are today. Both nations believe in government of the people, by the people, and for the people. Both are instinctively and unalterably opposed to dictators, no matter whether the dictator is an individual or a class. (17)

Schurman's views were echoed by others, such as Oswald Garrison Villard, the liberal editor of the Nation. He observed in early 1933, just before Hitler took over as Chancellor, that the Germans "are naturally friendly to America and far more like ourselves than any other European peoples, excepting the English." Assuming this to be true, Villard could not believe that they would entirely reject republican government:

That the Republic, for the moment, is but a shadow of what it was intended to be is undeniable. Yet it is difficult to believe that Germany with its traditions and its heritage will long remain at the mercy either of dictators or demagogues. (18)

During the Weimar years, Americans sometimes appeared to be looking for similarities between the German and American political traditions, or at least for evidence that the Germans were ready for self-government. As Villard noted, 
- . in various ways the Germans were not wholly ready for the democracy which in considerable degree $\mathrm{Mr}$. Wilson and the Allies forced upon them. . . . It must be pointed out here, however, that if no nation could, or should, assume the burdens and accept the penalties of a republican form of government until it is in every way ideally prepared for them, the world would to-day still be in the grip of absolute monarchies. (19)

This attitude, of course, was quite different from the one that had prevailed during World War I and would be seen again in the anti-German propaganda of World War II. As Hitler's atrocities became more apparent over the course of the 1930s, American observers returned to the World War I view that the Germans were incapable of understanding anything but brute force and power. (20)

In the Weimar years, however, some Americans asserted that the Germans should be able to hold a republic together. They were, as Villard had pointed out, far more like the Americans and the British than were, for example, the Italians, who had adapted so well to a Fascist dictatorship. In order to hold onto this view about German democracy, Americans were forced to ignore many of the facts about Germany's unreadiness for self-government and its inability to maintain order within its own borders.

British diplomats retained a less sanguine attitude than the Americans about German capabilities for selfgovernment. The British were also somewhat upset by the resurgence of pro-German feeling in America. Their charge: 
d'affaires in Washington reported with alarm on the

American popularity of John Maynard Reynes' 1920 book, The

Economic Consequences of the Reace, which urged the allies not to bleed Germany dry. To the British diplomat, America's sudden new concern for Germany's welfare was motivated by "both the idealism and the business-like instincts of the American people." The British also expressed frequent doubt about the German republic in view of Germany's militaristic past, passion for hierarchy, and "national character."

They perhaps remembered their history better than the Americans did. Lord Kilmarnock, the British Ambassador in Berlin, spoke gloomily of the Germans in 1920, when the republic had barely begun:

Trained as they have been for a century in the tradition of obedience, with a peasantry conservative in instinct, and the majority of their so-called socialists disciplined to a docile acceptance of the orders of those they have placed in power, it is by no means improbable that a strong Government may be established, which, even though democratic in form, will be autocratic in essentials... (22)

To Rilmarnock, the German character was highly suspect:

It is extremely difficult for a foreigner to understand the complex psychology of the German, whose nature is a combination of genuine kind-heartedness and of latent brutality. His character is not the less complex now, in the moment of his defeat. (23)

To the British, the Germans lacked the capacity for self- 
government, as was sadly demonstrated by their multiplicity of warring parties and factions:

This bewildering mass of parties which seems to be tending towards quot homines, tot

sententiae may be partly due to the absence of responsible political life in the past history of Germany. It certainly testifies to the incapacity of the Germans for compromise which to my mind is due to their complete lack of a sense of humour, a conception for which no equivalent exists in the German language. It is also possible that the German character has remained substantially the same since the days of Tacitus and that particularism and federalism now take the place of inter-tribal warfare and that the political entity now affects the wilderness which the primitive household wished to place between itself and its nearest neighbours. (24)

The maintenance of order was indeed a constant problem in the early years of the republic, and would prove even more difficult in the early 1930 s as parliamentary government disintegrated. The United States was committed to maintaining the republic, but was of ten thwarted by France's nationalistic demands for security, reparations, and German territory. In 1920, when the French occupied Frankfurt, Secretary of State Bainbridge Colby noted that this action could endanger the republic by bringing together destabilizing elements from both the militarist right and the radical left. He registered his protests as follows:

The Government of the United States can only reiterate its already expressed opinion that occupation of more territory in Germany promises to cause a junction of militaristic forces in Germany and elements of German 
people striving for revolution and the overturn of political and economic order.

Only a month before Colby wrote these words, Germany had experienced this very problem. Militarism had sprung forth in the form of the abortive Kapp Putsch, and various unsuccessful left-wing revolts broke out around Germany at the same time. The Secretary of State had summarized the two greatest threats to the unpopular fledgling republic -the militaristic right and the communist left. The Americans threw their weight behind "the efforts of the German government in its conflict with both the forces of reaction and militarism and of anarchy." And "anarchy," in the diplomatic documents of the time, was associated almost exclusively with Bolshevism and similar leftist revolutionary movements. At the time of the Kapp Putsch and the leftist revolts, Ellis Loring Dresel, the Commissioner at Berlin, spoke of "lawlessness and anarchy," and saw the Weimar government as "the only agency capable of preventing a state of utter chaos." He received a response from Washington expressing the same fears in even stronger language, noting the government's "conflict with both the forces of reaction and militarism and of anarchy" and the necessity of "preserving democracy and . . upholding law and order against those sinister and antidemocratic elements which would plunge Germany into a state of lawlessness and anarchy." 
American fears of German militarism had a long history and were well justified. Nevertheless, Communism was the threat that held the most weight with both the Americans and the British, and the German leaders were aware of this fact. They knew the value of the "bogey of Bolshevism" and invoked it often when dealing with the Anglo-American diplomats. The threat had been used at Versailles to get more lenient treatment in the armistice, and would reappear throughout the life of the Republic.

During the abortive right-wing Kapp Putsch, which came at the time of America's postwar Red Scare, Weimar leaders were already showing an astute sense of how to get attention. To draw attention to their own plight and to ensure their own perpetuation in power, they turned again to the possibility of a Bolshevist triumph:

Bauer, Chancellor, and Schiffer, Minister of Justice, in a talk with a reliable American correspondent, stated that the political situation was very precarious. They stated that the most promising means of saving Germany and all Central Europe from Bolshevism would be a strong statement by the American President whose word would carry great weight if he declared that no raw materials or foodstuffs could be furnished a Germany adopting an ultraradical form of government. (28)

The disastrous inflation of 1922-23 also brought widespread economic discontent and seemed the perfect breeding ground for Bolshevism. One consular officer in Munich observed later that during this period, The chaotic condition of society was such that 
there was genuine reason to fear that Bolshevism might take the same advantage of confusion in Germany and Austria which it had taken in Russia after the collapse of the

Czarist empire. (29)

In November 1922, the American Ambassador to Germany, Alanson B. Houghton, sounded a similar refrain when discussing the grave situation of the poor in Europe and particularly in Germany: "There is no future to beckon them on, unless it be the mirage of Bolshevism." Houghton, an old-fashioned Ivy League American diplomat, who had seen the tragedies inflicted by Bolshevism in eastern Europe, went on to describe the possibility of the European republics falling like dominoes:

Already the Bolshevist tide is beating against the barriers of European civilization. And if once those barriers go down, if the German people, in despair, believing that sympathy and help and understanding of their position are denied them, turn for relief to the East, the time is past. That tide will sweep resistlessly to the Atlantic. (30)

To an old-line diplomat and American Brahmin such as Houghton, America had a mission: "God has been good to us in America. He has made it possible for us to create and pile up huge wealth." That wealth, in his view, had to be used to shore up the forces of order in Germany: "When one sees the forces of civilization in the balance, one must be lacking in moral courage to withhold any suggestion that points to safety... . " (31) Many of the same fears of Bolshevism and disorder haunted America's British partners 
in status quo diplomacy. Colonel McGrath of the British War Office observed in 1923 that Germany was "on the brink of economic collapse" and that "this form of collapse is the best breeding ground for Communist germs . . . .

Fears of Communism in Germany were further encouraged by Gustav Stresemann, who served as German Chancellor for a short period in 1923 and as Foreign Minister from 1923 until his death in 1929. Stresemann was a highly respected diplomat, admired by both Lord D'Abernon, the British ambassador to Germany from 1920-26, and Sir Horace Rumbold, his successor. (33) He was also a "pragmatic conservative" who would have preferred a constitutional monarchy for Germany but supported the republic as a lesser evil than the only visible alternatives - a dictatorship of the right or the left.

Stresemann's aims included freeing Germany from foreign occupation, solving the reparations problem in a way acceptable to Germany, protecting German nationals abroad, recovering Danzig and the Polish corridor, and adjusting the frontier of Upper Silesia. (35) His insistence on the use of finesse, not force, to achieve German objectives, alienated him from the German Nationalists, the Nazis, and the paramilitary and Reichswehr (army) groups -- this despite his covert assistance to the Beichswehr's efforts to rearm secretly in violation of the Versailles treaty's restrictions. 
Western fears of Bolshevism and American financial interests in Germany stood at the center of Stresemann's revisionist strategy:

As early as 1920 his political analysis had defined the four cardinal points around which he would build his future policy: (1) direct negotiations with France, (2) the balancing potential of England, (3) the vital interests of the United States in a stable and highconsumption market in Europe, and (4) the Western powers antipathy and sense of anxiety regarding Bolshevist Russia. From these points, Stresemann conceived the necessity of a foreign policy aimed at the simultaneous "recognition (as a consequence of the lost war) and revision (as the desirable aim of any national German foreign policy) of the Treaty of Versailles."

Within the framework of this policy of simultaneous recognition and revision, Stresemann pursued a balance between East and West, believing that Germany's long-range opportunities lay in the tensions between Soviet Russia and the capitalist powers.

Stresemann's chief objectives in foreign policy centered on the revision of the Versailles Treaty, a lasting source of German bitterness because of its accusation of war guilt and demands for German reparations and disarmament. He played on British and French fears of the Soviet Union, insisting that an economically and militarily strong Germany was the only bulwark against a Soviet takeover of Europe. Thus he saw the German Communist riots of the 1920 s as a "splendid opportunity" for the creation of foreign policy, since they illustrated his view that an impoverished, disarmed Germany would be easy prey for the Communists. Throughout the 1920s, he 
punctuated his discourse with constant warnings of a "bolshevik flood" which could take over all Europe if Germany were not restored to its former strength.

As we have seen, the two major threats to Weimar democracy in the early 1920 s were the resurgence of militarism and the emergence of Bolshevism. The early Nazis played a relatively minor role in the thinking of American and British diplomats. At this time Nazis were merely one of many right-wing splinter parties based in Bavaria. The first American government report on Hitler and the Nazis was written in 1922. Despite the chiefly regional emphasis of the early Nazis, Ambassador Alanson B. Houghton sent his observer, Captain Truman Smith of the military attache office, to interview Hitler in November 1922, one year before the Beer Hall Putsch. This was largely an afterthought on Houghton's part, as the main subjects to be interviewed in Munich were Prince Ruprecht, pretender to the Bavarian throne, and Erich von Ludendorff, the World War I military hero, whose political ambitions Houghton wanted to determine. (39)

Ludendorff had by this time become a Nazi supporter, and he lectured Smith on the ineffectiveness of the Weimar Republic and the need to stamp out Bolshevism in Germany. Only a strong nationalist government, he insisted, could preserve Germany from chaos and ensure further payment of reparations. Hitler himself depicted his group primarily 
as an anti-Marxist movement. He insisted that only a dictatorship could properly govern Germany, and that parliamentarism must be ended. He, like Ludendorff, played to American interests by insisting that reparations must be paid, though at a reduced rate, for Germany to regain its reputation. He insisted it was better for America and Britain that the struggle against Bolshevism be fought on German soil.

Smith reported Hitler's statements as follows:

If we (America) do not help German nationalism, bolshevism will conquer Germany. Then there will be no more reparations, and Russia and German bolshevism, out of motives of selfpreservation, must attack the Western nations.

He called Hitler "a marvelous demagogue." (40) His group, Smith concluded, was more a popular movement than a political party, and "must be considered as the Bavarian counterpart to the Italian Fascisti" who had just completed their March on Rome a year earlier. At this point, Hitler was emphasizing some of the same policies as Mussolini, including anti-Bolshevism, reconciliation with foreign powers (such as France), and financial solvency through the repayment of reparations. Smith noted, however, that in his conversation Hitler omitted one of the chief planks of his party's propaganda, and one of his characteristic differences from Mussolini -- his notorious anti-Semitism. (39)

In a draft magazine article from 1924, Smith noted the 
Nazi leaders" claim to be "the Fascisti of Teutonic Europe, yearning to give their country the benefits of a Mussolini statesmanship. . . ." but concluded that their resemblance was limited mostly to the outward trappings of Fascism: "The Mussolini genius, however, with that theatricalism so correctly pitched to the Italian temperament, has escaped them." He dismissed the Nazis as a "crude Teutonic imitation, with anti-Semitism substituting for the absent "essence" of Italian Fascism. However, he disputed those who scoffed at Hitler's chances for power, and insisted he could pose a danger if economic prosperity did not return to Germany. (42) British observers of the same time noted many of the same tendencies as Smith did, including Nazi violence and anti-semitism, and referred to Hitler as "the Bavarian Mussolini."

Thus, it is apparent that early British and American observers of Hitler (most of whom were military men, not diplomats) saw his movement as an imitation or variant of Mussolini's Italian Fascism, which in some ways it was. This is a notable contrast to the views of the diplomatic observers of the early 1930s, who, for reasons to be discussed later, often tended to see the Nazis as something more akin to Bolsheviks than Italian Fascists. In the early 1920s Hitler was interpreted, with considerable justification, as a cheap and relatively minor German imitator of Mussolini. 
The changes in Hitler and the Nazi party over the course of the decade made the early Nazis fundamentally different from the party that would confront diplomatic observers in the early 1930s. The failed Beer Hall Putsch of 1923 and Hitler's subsequent jail term, during which he wrote Mein Kampf, modified the party in significant ways. Hitler abandoned the idea of a "March on Berlin" modeled on Mussolini's experience, and instead worked toward taking power by legal methods, achieving mass mobilization, bringing in new members from a larger geographical area, and creating a system of total obedience to himself as the Eührer. (44)

After a mockery of a trial that largely served to gain Hitler nationwide publicity, he was sentenced to the minimum term of five years in prison for his part in the Beer Hall Putsch. The Nazis were one of many right-wing splinter groups in Bavaria, and were pampered and financed by leading Nationalists and conservatives. (45) Hitler's stay in prison was comfortable and considerably shorter than his actual sentence. In prison he found time to write Mein Kampf, the ostensible intellectual foundation of Nazism. As historian Alan Bullock has noted, Every one of the elements in his worldview is easily identified in nineteenth-century and turn-of-the-century writers, but no one had previously put them together in quite the same พау. (46)

Hitler claimed influences from Nietzsche, Ranke, 
Treitschke, Marx, Bismarck, Lanz von Liebenfels and others, but his reading appears to have been mostly a search for a framework on which to hang his "vulgarised Darwinian ideas." (47) However, Hitler had little use for ideas throughout his career, since he understood that the method of propagating ideas was the real key to power. To him, policies, tactics, and platforms were always matters of mere expediency, and he kept his terms as vague as possible in order to keep from being committed to any particular course of action. In a favorite demagogic slogan, Nazi Gregor Strasser even described National Socialism as "the opposite of what exists today."

In the early years of the party, there is evidence that Hitler regarded himself less as a charismatic leader on the Mussolini model than as a "drum-major" creating support for nationalist goals. In the years before Hitler's prison term, the Nazis had worked closely with other right-wing nationalist groups and concentrated almost solely on taking power through a putsch (for example, the party did not compete in a single election before 1924). (49)

The mid-1920s were not a good period for the Nazis, who were rarely a focus of interest by American and British diplomats during this period. The Bavarian government and most other major provincial governments in Germany had banned Hitler from making speeches between 1925 and 1928 . 
Given Hitler's extraordinary prowess as a speaker, the lack of compelling orators among the other Nazis, and Hitler's own views on the superiority of the spoken over the written word as a propaganda vehicle, this was a devastating attack on the Nazi party's major attraction.

Also, these years had brought relative prosperity, spurred by foreign capital, with the national income reaching prewar levels. Unemployment was minimal in 1927 , and in an atmosphere of stability and prosperity Hitler's negative message gained few adherents. In 1928, the ban on Hitler's speaking was 1 ifted, and the number of party members had risen to 60,000 from 17,000 in 1926. Still, the Nazis only gained 12 seats in the Reich elections of 1928 -- less than half their stated goal, and barely enough to make them a notable splinter party.

The Nazis only reached national prominence as the Depression intensified, unemployment skyrocketed, and Hitler capitalized on the enormous publicity he got as a leader of the 1929 campaign against the Young Plan, which was financed from the deep pockets of publishing magnate and Nationalist leader Alfred Hugenberg. The Nazi party did not become the focus of major international attention again until its massive election victory of September 1930, but some of the earliest American impressions of the Nazis remained over time, even after the reality of the party had changed considerably. Up to the last days of the Weimar 
Republic, American diplomats often persisted in seeing the Nazis as a divided party under several leaders (some of whom -- such as Gregor Strasser --seemed alarmingly communistic). Rarely was Hitler perceived as an absolute leader on the Mussolini model, largely because Mussolini was seen as a statesman and Hitler was still continually underestimated by observers of all nationalities.

Interestingly, the fear surrounding Hitler was not so much that he might rule with an iron fist, but rather that he would not be able or willing to control the disparate elements of his party. As late as 1932, in his Talks With Mussolini, German biographer Emil Ludwig dismissed the possibility of successfully exporting Fascism to his native Germany, insisting that "on the German stage there is no star performer competent to play the part of Fascist leader." (52) By this time Hitler was a major player in German politics, and by expressing such sentiments Ludwig was explicitly indicating that he could not develop into another leader of the caliber of Mussolini.

In the early years of Hitler's political activity, American and British observers saw his party as a Fascist growth modeled after Mussolini's party, yet they refused to take him seriously as a leader. This made sense in view of the fact that he had as yet done little to warrant such attention. The most he could be, in their view, was a sort of third-rate, tinhorn, failed version of Mussolini. This 
attitude changed markedly in the early 1930 s as Hitler's party emerged as a real force in German politics. At that time, the American and British diplomats described the Nazis as resembling Bolsheviks and numerous other political groups, but rarely as resembling the Italian Fascists.

This was due in part to some genuine differences in strategy, tactics, and ideology between the two Fascist leaders and their parties. Yet most of it all it was based on a profound admiration of Mussolini in both America and Britain, which lasted up to the time of the Italian invasion of Ethiopia. It was difficult for the AngloAmerican policy elite to see any real resemblance between Hitler, the man who was setting out to destroy economic stability in Europe, and Mussolini, who was devoted to its preservation. 


\section{ENDNOTES}

(1) On the expansion of American business interests in Europe (and particularly Germany) during the 1920s, see Emily S. Rosenberg, Spreading the American Dream: American Economic and Cultural Expansion, 1890-1945 (New York, 1982). Of particular interest are Chapter 7, "Economic Expansion: the 1920s (122-137) and Chapter 8, "The Cooperative State of the 1920s" (138-161), which describe American business and financial expansion and the close interaction between business and diplomacy during this era. A contemporary account of American predominance in Europe is Edgar Ansel Mowrer, This American World (New York, 1928).

(2) Eberhard Kolb, The Weimar Republic, trans. P.S. Falla (London, Unwin Hyman, 1988), 3. Erich Eyck, A History of the Weimar Republic ( 2 vols. Cambridge, Mass., 1963), I:71.

(3) Eyck, Weimar Republic, I:69-70.

(4) Kolb, Weimar Republic, 152, 151, xiii.

(5) Ibid., 34, 67-8.

(6) Eyck, Weimar Republic, I:71.

(7) "Message of the President of the United States to Congress, December 7, 1920," ERUS 1920 I:vii.

(8) Ellis Loring Dresel, Commissioner at Berlin, to the Acting Secretary of State, March 21, 1920, ERUS 1920, $I: 268$.

(9) Owen Young, Speech to Foreign Policy Association of Cincinnati, January 6, 1926, O.D. Young Papers (in family possession, Van Hornesville, New York), cited in John M. Carroll, "Owen D. Young and German Reparations: the Diplomacy of an Enlightened Businessman" in Kenneth Paul Jones, U.S. Diplomats in Europe, 1919-1941 (Santa Barbara, 1981; reprint ed., 1987), 43-44.

(10) Hyde (Solicitor for the Department of State) to State, Washington, December 5, 1923, ERUS 1923, 2:28; Article I, "Treaty Between the United States of America and 
Germany, Signed at Washington, December 8, 1923," ERUS $1923,2: 30$.

(11) Carter, "America's Present Role in World Affairs," 161 .

(12) B.J.C. McKercher, The Second Baldwin Government and the United States, 1924-1929 (Cambridge, 1984), 2.

(13) Ibid., 2-3; Calvin Coolidge, "Message of the President of the United States to Congress," December 3 , 1924, ERUS 1924 1:xix; Herbert Feis, 1933: Characters in Crisis (Boston, 1966), 15-16.

(14) Cohen, Empire Without Tears, 33; the borrowingto-reparation figures are from Hans-Joachim Braun, The

German Economy in the Twentieth Century (London, 1990), 45. Braun sees the reasons for the Great Inflation of 1923 as going back to World War I causes (see 39-40).

(15) On concerns about loans to German states and municipalities, see ERUS 1925 $2: 173-87$ and ERUS 1926 2:2014. For a characterization of S. Parker Gilbert and his central role in Germany in the 1920s, see Louis Fischer, Men and Polities (New York, 1941), 102-3.

(16) Dulles' views are from Nancy Lisagor and Frank Lipsius, A Law Unto Itself: The Untold Story of the Law Eirm Sullivan and Cromwell (New York, 1988), 83-35. This book holds Dulles, a major partner of the firm, responsible for many of the ill-advised loans made to Weimar Germany and even for trade with the Nazis in the 1930s. Mowrer's comments are from Edgar Ansel Mowrer, "Germany After Ten Years," Harper's 158 (December 1928), 61.

(17) Schurman is quoted in Hans W. Gatzke, Germany and the United States: A "Special Relationship?" (Cambridge, Mass., 1980), 1 .

(18) Oswald Garrison Villard, The German Rhoenix: The Story of the Republic (New York, 1933), 64, Foreword.

(19) Ibid., 24.

(20) For a few extreme examples of the World War II propaganda depicting Germans as a militaristic people incapable of republican government, see the following books: Lord Robert Vansittart, Lessons of My Life (New York, 1943), the rabidly anti-German work of a leading British diplomat, portrays the Germans as utterly powercrazed, and Wladyslaw Kulski, Thus Speaks Germany (New 
York, 1941; reprint ed., AMS Press, 1973) a collection of racist, ultra-nationalist, anti-democratic quotes from various German authors. For a World War I equivalent, see John Jay Chapman, compiler, Deutschland Uber Alles or Germany Speaks (New York, 1914). Also helpful is Edgar Ansel Mowrer, Germany Puts The Clock Back (New York, 1933, rev. ed. 1936) which includes the ever-mercurial Mowrer's reassessment of the Germany he had seen as a viable republic only a few years before.

(21) Mr. R.C. Lindsay, (Acting Charge' d'Affaires at Washington) to Earl Curzon, February 24, 1920, \#123, DBFP I : 10, 202-203.

(22) Lord Rilmarnock (British Ambassador to Germany) to Curzon, February 10, 1920 (Enclosure), \#38, DBEP I:9, $57-58$.

(23) Mr. Cecil Gosling (Consul, Frankfurt) to Curzan, June 12, 1920 (Enclosure, "Report on the elections in the Consular District of Frankfort on-the-Main, together with notes on political conditions in South West Germany"), \#523, DBEP I:9, 546 .

(24) Robert T. Smallbones (Consul, Munich) to Curzon, September 28, 1920, \#219, DBFP I: 10, 310 .

(25) Bainbridge Colby (Secretary of State) to the Ambassador in France (Wallace), April 12, 1920, ERUS 1920 2: 324 .

(26) Ellis Loring Dresel (Commissioner at Berlin) to the Acting Secretary of State, March 19, 1920, ERUS 1920 $I: 267$; Polk (Acting Secretary of State) to Dresel, March 22,1920 , ERUS 1920, I:269.

(27) Edward Hallett Carr, German-Soviet Relations Between the Two World Wars, 1919-1939 (Baltimore, 1951), 9; John M. Thompson, Russia. Bolshevism. and the Versailles Reace (Princeton, 1966), 20-21. See also Arno J. Mayer, Politics and Diplomacy of Peacemaking: Containment and Counterrevolution at Versailles 1918-1919 (New York, 1967), which deals in depth with the issue of how the Bolshevik revolution affected the treatymaking process.

(28) (The Commissioner at Berlin) to the Acting Secretary of State, March 21, 1920, ERUS 1920 I:268-9. As for the "reliable American correspondent" described in this quotation, see Heald, Transatlantic Vistas, 137-8 on the increasing involvement of foreign correspondents in American diplomacy during this period. 
(29) Robert Murphy, Diolomat Among Harriors (New York, 1964), 14.

(30) Alanson B. Houghton to State, October 23, 1922, ERUS 1922 I : 173 .

(31) Ibid., 174-5.

(32) Col. MeGrath, War Office, to Mr. Lampson, \#284, DBEP $I: 21,378$.

(33) Henry L. Bretton, Stresemann and the Revision of Yersailles: A Eight for Reason (Stanford, 1953), 8; Rumbold to Henderson, October 10, 1929, \#22, DBFP 1A:7, 42.

(34) Henry Ashby Turner, Stresemann and the Politics of the Weimar Republic (Princeton, 1963), 263, 103-4, 264.

(35) Hans W. Gatzke, Stresemann and the Rearmament of Germany (Baltimore, 1954), 113.

(36) Ibid., 111-12.

(37) Robert P. Grathwol, Stresemann and the DNVP: Reconciliation or Revenge in German Eoreign Rolicy--19241928 (Lawrence, Kansas, 1980), 5.

(38) Bretton, Stresemann and the Revision, 151, 39, 148, 139. For an example of Stresemann invoking the "bolshevism bogey" in the earliest years of the Weimar Republic, see Lord Kilmarnock (Berlin) to Earl Curzon, July 14,1920 , \#177, DBEP I: 10, 272-273. In this document and many others (see \#179, \#180, \#183, \#192, \#194 in the same volume, and DBFP I:9, \#9, \#81, \#98) the British diplomats discuss fears of Bolshevism raised by right-wing German leaders including General Ludendorff and right-wing industrialist Captain Arnold Rechberg. The more extreme anti-Bolshevik schemes of these leaders, which included scrapping the Versailles Treaty, were faithfully reported but only rarely taken seriously by British leaders (see Curzon's comments on $\# 193$ and J.P.T. Bury's comments in the preface to DPEP I:10, vi.

(39) Robert Hessen, Introduction to Berlin Alert: The Memoirs and Reports of Truman Smith (Stanford, 1984), xiv.

(40) Truman Smith, "Notebook of Captain Truman Smith, Infantry, U.S. Army Assistant Attache', Berlin, Germany, November, 1922," entries for Sunday, November 19 and Monday, November 20, 1922, ibid., 58-59, 60-61. 
(41) Truman Smith, "Conditions in Bavaria: The National Socialist Labor Party Service Report, 1922", Report of the Military Attache' Office, Berlin, Germany, November 25, 1922, to the Division of Military Intelligence, War Department, Washington, D.C, ibid., 62-3.

(42) Truman Smith, "The German 'Fascisti,' Draft magazine article prepared in June 1924, ibid., 68-9.

(43) Mr. Smallbones (British Consul in Munich) to Earl Curzon, September 28, 1920, \#218, DBEP I:10, 310; Consul-General Seeds (Munich) to Curzon, \#316, DBEP I:20, 599. In J.P.T. Bury's preface to DBEP I:10, viii, he refers to Smalibones as the first mention of the Nazis in the British diplomatic papers.

(44) Kolb, The Weimar Republic, 97.

(45) Alan Bullock, Hitler and Stalin: Parallel Lives (New York, 1992), 137; Joachim C. Fest, The Face of the Third Reich: Rertraits of the Nazi Leadership (New York, $1970), 20$.

(46) Bullock, Hitler and Stalin, 141.

(47) Fest, The Eace of the Third Reich, 27, 10.

(48) Ibid., 14; Bullock, Hitler and Stalin, 156; the Strasser quote is from Fest, The Eace of the Third Reich, 32 .

(49) Kolb, The Weimar Republic, 97.

(50) Fest, The Eace of the Third Reich, 32, 17.

(51) Ibid., 32; Bullock, Hitler and Stalin, 149, 155.

(52) Ludwig, Talks With Mussolini, 6. 


\section{CHAPTER V}

THE AMERICAN DIPLOMATS AND THE WEIMAR REPUBLIC, 1930-33

In September 1930, an extraordinary event transformed the course of German political history. Hitler's Nazis made astounding gains in the German elections, increasing their representation in the Reichstag from 12 to 107 members. The German Communist Party (KPD) also made significant gains, and suddenly the focus of American leadership fell upon the critical situation in Germany, where dissatisfaction with the status quo had led to a situation of dangerous destabilization. Before examining the Anglo-American diplomats' reactions to the Nazi Party's milestone victory and ascent to power, it is necessary to describe some of the personalities and governmental factors affecting their policies and perceptions of German events in the early 1930s.

The tone of America's politics and diplomacy in these years was set by the President, Herbert Hoover. A brilliant engineer, administrator, and economist, Hoover had been one of the outstanding figures of America's prosperous "New Era" of the twenties. After spearheading the postwar European food relief campaign, he led the Commerce Department through a period of extraordinary 
expansion at home and abroad, leading one American official to refer to him as "Secretary of Commerce and Under-

Secretary of all other departments."

It was Hoover's misfortune to become President in the most difficult of times. He was elected in 1928 , the stock market crash followed in October 1929, and the Great Depression intensified relentlessly throughout his single term in the White House. Hoover was a man of great virtues --brilliant, principled, and extremely hardworking, but he also had an unfortunate lack of charisma and several other traits that were problematic at a time when the nation needed a boost in its morale. He was notoriously taciturn and gloomy, and became more so as the economic situation worsened. His Secretary of State, Henry L. Stimson, noted his predilection for "seeing the dark side first," and Esme Howard, the British Ambassador, called him "without exception, the most difficult American to know whom I have ever met."

Hoover had extensive international experience, perhaps more than any previous president. Yet he remained "absorbed in a fog of gloom" while trying to solve the domestic problems of the Depression economy, and thus left most of the conduct of foreign policy in the hands of Secretary Stimson. (3) Hoover's attempts to solve the economy's problems were heavily reliant on voluntary cooperation between business and the White House, with 
Congress in the role of spectator. Yet as the Depression worsened, so did the conflicts with Congress, the press, and the public, leaving the president in an ever more embattled position.

Hoover prized loyalty over experience in elective office among his cabinet members, who were generally business-oriented and somewhat apolitical. In Secretary Stimson, however, he found a man of admirable loyalty and experience despite their admitted differences of temperament. (5) Stimson has been called "the founding father and patron saint" of the American foreign policy establishment because of his fifty-year career near the center of power. As a diplomat, Secretary of State and Secretary of War, he served presidents of both parties and various personalities, ranging from Theodore Roosevelt to Harry Truman. As a protegé of the old Progressive nationalists and a product of the highest reaches of the American aristocracy, he was well-suited to the task of helping the United States ascend to global power, a mission he believed in firmly though less vocally than other old nationalists of Theodore Roosevelt's generation.

Stimson was "the very paradigm of the American gentleman," a man of absolute personal and public rectitude who inspired great loyalty in his subordinates. His impeccable background -- Phillips Andover Academy, Yale College, Skull and Bones, Harvard Law -- made him a fitting 
leader for the very patrician Foreign Service of the era and for the emerging period of Anglo-American international cooperation. Men of Stimson's background saw themselves as "the equals of the British and the superiors of everyone else." He had spent much of his youth in Paris and London, and admitted to having strong sympathies for the British and French and a distrust of German militarism.

American Ambassadors to European nations in the 1920 s and 1930s, as today, were appointed by the President with the Senate's advice and consent according to the "spoils system" dating back to Andrew Jackson. This has traditionally led to an uneven quality of American representation abroad, including the accession of a fair number of "political hacks and lame ducks as well as genuinely worthy statesmen."

However, the spoils system also has offered certain advantages -- the prestige of some big-name ambassadors, their access to the higher corridors of power, and their ability to pay their own expenses (an important point, as American diplomacy has traditionally been an underfunded profession). As amateurs, however, American ambassadors were subject to accusations, sometimes justified, of excesses of sympathy or antipathy toward foreign leaders and regimes. Their advice to the State Department was often discounted, and their access to the President sometimes caused antagonism within the diplomatic 
bureaucracy.

(10)

President Hoover was no exception in practicing the spoils system, leading to some degree of disgust among oldline professional diplomats. Hoover had already made himself "hated in the State Department" during his days as Secretary of Commerce for keeping tight departmental control over American commercial attaches abroad and for siding with the President against the State Department.

(11) The resentment of professional diplomats was expressed well by Lewis Einstein, a "career man" who served as minister to Czechoslovakia from 1921 to 1930. Einstein was a member of a prominent New York Republican family and a prime example of the cultured old-style career diplomat. President Hoover abruptly accepted his untendered resignation in 1930, removing him from his post. His observations many years later still rankled with the rivalry between the career men and the less diplomatically experienced political appointees:

The ease with which he [Hoover] dropped many career men was not calculated to flatter their self-esteem, though doubtless it provided some lessons in humility. The presidential purpose was only one of utilizing diplomatic posts as a hidden subsidy for administration politics. My successor in Prague obtained his training for world affairs by running a taxi company. (12)

Frederic Sackett, Hoover's choice for Ambassador to Germany, fit the "lame-duck political appointee" characterization in some ways, yet he also brought valuable 
experience to his position. Sackett was a prominent Kentucky businessman and Senator, appointed as Ambassador in part because he was perceived as a lame duck with little chance of reelection because of factional struggles within the Kentucky Republican party. However, he fulfilled the State Department's desire for an ambassador well versed in business matters, "because paramount issues of concern to the American embassy involved World War I reparations and trade relations with the Weimar Republic."

When he became Ambassador in 1929, Sackett replaced Jacob Gould Schurman, a former president and philosophy professor at Cornell University who had also served as minister to Greece and China. Despite his openly antiGerman views during World War I, Schurman had been perceived by State Department sources as being too proGerman.

As a businessman, Sackett appeared more likely to represent and guard American interests. However, he later became very involved -- perhaps too involved -- in the affairs of his host country, and even exploited his personal access to President Hoover in a desperate effort to maintain the regime of his close friend and political ally, Chancellor Heinrich Brüning.

In his reporting on German politics, Sackett was assisted chiefly by Counselor of Embassy George A. Gordon, an old-fashioned career diplomat, "an industrious career 
man with punctilio developed to the ath degree."

Gordon, known for his volatile temper, offered colorful descriptions of the Nazis but did not make much of an effort to meet with them and discern their motives. In this sense, the Americans may have been deprived of some of the needed analysis of the Nazi phenomenon. (17)

One of the more perplexing problems surrounding German Nazism is that of the extent to which it resembled Italian Fascism as a revolutionary movement and later, as a governmental regime. Scholars continue to argue about whether the notion of a "generic Fascism" or a "fascist minimum" of criteria constituting a fascist government can be defended. (18) The question remains as to whether Nazism represented a separate, purely German movement apart from Italian Fascist antecedents, but in any case Hitler had certainly copied many of the outer trappings of Mussolini's Fascist regime -- the pageantry and raised-arm salute, the attempted Beer Hall Putsch that imitated the March on Rome, the hastily improvised and highly flexible political program, and the paramilitary squads of disaffected young men.

In the years before Hitler took power, Americans in general viewed his Nazi party as a Germanized version of Italian Fascism. An American study of German civic education, published within months of Hitler's 1933 takeover, announced that "Fascism has triumphed in Germany" 
and referred to the Nazis as "Fascists" throughout, using the word "Nazi" in quotation marks only. Most of the very early references to the Nazis by American diplomats called them the "German Fascists" until the colloquial term "Nazi" became common in American usage. (20) The conventional wisdom at the time was that Nazism was in some way an outgrowth of Italian Fascism.

Yet during the immediate period of Hitler's rise to power, from the September 1930 election to Hitler's assumption of the chancellorship in January 1933, the American diplomats serving in Berlin made few direct comparisons between Hitler and Mussolini. At this time, when magazine pieces were referring to Hitler as "Germany"s Would-Be Mussolini" and editorial cartoons showed him trying to follow in II Duce's footsteps, the American diplomats in Berlin were rejecting the notion that Nazism was closely related to Italian Fascism. (21) Parallels with Mussolini were seen by American diplomats in Washington, and would later come from diplomats who served in Germany after observing Mussolini's curtailment of civil liberties in Italy. Yet the Berlin embassy staff looked at the rising Nazis and saw something quite different than what Mussolini had created in Italy.

In December 1931, the State Department in Washington sent the Berlin embassy a memorandum prepared by Herbert Feis, the Department's economic adviser. Feis's 
observations were "based for the most part on newspaper reports" and were sent along because "We have not had any reports from the Embassy which have covered this question in just the same way as this memorandum approaches it," namely acknowledging the question of the connection between Nazism and Italian Fascism. The memorandum noted "The extent to which [Hitler's] program and ideas seem to resemble those of Fascist Italy."

In response to the State Department's request for "amplification or added information" for the memorandum, the Berlin Embassy responded as follows:

The program of Fascist Italy really has little in common with that of the Nazis in Germany. Whereas Fascism is based on the idea of a cooperative state, Hitlerism is based on the old Hohenzollern and Prussian idea of strong centralization, imperialism and expansion . . . The programs are similar in that both Fascism and Hitlerism depend on chauvinism and are opposed to emigration of their peoples. Whereas in the latter the element of antiSemitism plays a prominent role, it is entirely lacking in the former. The substance of Fascism is Mussolini's personality; the same applies in a much lesser degree to Hitlerism. Mussolini has the intellect and bearing of a martial hero; Hitler has the intellect of a crusading sectarian leader -- oblivious of dangers which surround him --but with intense energy and relentless in the pursuit of his aims. (23)

In the above paragraph are several notable features of the Berlin Embassy view of Nazism. The first is the acceptance of the notion, widely believed at the time, that Mussolini had succeeded in the creation of a "corporate 
state" that fundamentally organized labor and capital into a permanent, government-controlled bloc (something widely believed at the time but largely untrue) and that Hitler, if he came to power, would impose something radically different but as yet unknown.

Another notable feature is that the embassy staff saw Nazism as stemming less from Italian Fascism than from indigenously German centralist and militarist traditions. There is much truth in this observation, and Prussian militarism and monarchism seemed ready for a resurgence, considering the power of the Hugenberg Nationalists and other right-wing groups. Pierre de Lagarde Boal, the Chief of the Division of Western European Affairs, did not discount the possibility of a coup detat to restore a member of the imperial family. As he noted, "Discouragement with the republic is strong in Germany. If a German looks backward the first happy period his memory reaches is in the reign of the last Raiser."

The most important component of the Berlin embassy analysis was the underestimation of Hitler's power as a leader -- an underestimation common to most observers up to and even after the Nazi takeover. The attitude was shared by many, including the ill-fated wheeler-dealers who brought Hitler into the government thinking they could "tame" him. The Berlin embassy staff definitely understood the extent to which Italian Fascism was Mussolini, but they 
did not yet comprehend the extent to which the Nazi Party was Hitler. Hitler still seemed to have the traits of the rabble-rousing "sectarian leader" or "drummer" of the early 1920s (26), while Mussolini had, in their view, the bearing of a "martial hero." Or even, perhaps, a statesman. Paul Scheffer, a Berliner Tageblatt reporter writing in Eoreign Affairs in 1932, noted the overwrought nature of Hitler's oratory and his lack of a concrete program. While Mussolini himself had lacked a program in the beginning, Mussolini, he noted, "has been a statesman and not merely a stirrer of emotions." This was similar to Emil Ludwig's view, expressed the same year in Talks With Mussolini, that there was no German personality strong enough to impose a true Fascist regime in Germany --an obvious slap at Hitler, though his name was not mentioned.

The apparently chaotic nature of the Nazi movement made it even easier to arrive at this conclusion. There appeared to be other leaders within the party, including the left-leaning wing of Gregor Strasser, and these factions received a fair amount of attention. Hitler's "legalistic" stance, his determination to enter the government by legal means, and the persistent efforts of other politicians to "tame" him, contributed to the impression that Hitler was a minor, blustering figure who could be handled by moderate German leaders if they would take the initiative to do so. 
Meanwhile, the "bolshevism bogey" remained a favorite of Foreign Minister Stresemann and other German leaders. One British despatch of 1928 tells of Stresemann describing the parties of the German far right as "supported by Italian money... . They called themselves sometimes Fascists, but they were really Communist. . . . (30) The British were inclined to take some of Stresemann's more alarmist statements with a grain of salt ( 31 ), and yet it is notable that in the late $1920 \mathrm{~s}$, British diplomats regularly described the Nazis as something more akin to Communists than Fascists. In 1929, the head of the British High Commission in the Rhineland, called the Nazis a "bolshevik-fascist organization," (32) and the Commission prohibited the wearing of the Nazi uniform within the British zone of occupation, though back at the Foreign Office it was observed that "The National Socialists are so near being ridiculous that it would be a pity to make martyrs of them." (33) In his 1929 report on the emergence of Nazi strength in local government elections, Harold Nicolson called the Nazis "red fascists, or leftwing jingoes," and noted their appeal to youth with the "extreme idealism" and socialist elements of their baffling program. (34) As the Nazis, with their "vigorous, if utopian" program, siphoned ever more votes away from the other, reactionary German Nationalist groups, they increased the "danger to public order" through "the danger 
of irresponsible fascism," apparently as opposed to Mussolini's responsible variety of fascism.

In 1929, the British were more seasoned observers of the Nazis than were the Americans. Sir Horace Rumbold, the British ambassador in Berlin, showed an early understanding that the National Socialist party was something entirely new in politics, mixing elements of Communism and Fascism in unheard-of combinations:

. Herr Hitler's party aims at something
new, something more bewildering than ever. It
aims at nothing less than reconciling opposite
political poles. The catchwords of the extreme
right and of the extreme left are jumbled
together in a manner which defies analysis. (36)
The same expressions of exasperation would be echoed by American diplomats after the huge election victory of September 1930 made the Nazis a major force in German politics. The American chargé d'affaires in Berlin, George A. Gordon, attributed the phenomenal September 1930 Nazi election gains to "disgust and recklessness." He was perplexed and appalled by the "extraordinarily confused, self-contradictory and opportunist character of their campaign." The Nazis were willing to say whatever was necessary to get votes, lauding private property when in areas dominated by the ultra-conservative Nationalist party, and then insisting when in Communist-dominated regions that they could offer "a Communist form of government directed by Germans rather than the same thing 
under the guidance of Moscow." Gordon was perhaps most upset by what seemed to be Nazi advocacy of "repudiation pure and simple." (37)

In keeping with this fear of repudiation, one of the more disturbing problems for the American diplomats was the lack of a coherent economic program among the Nazis. Gordon characterized the more extreme Nazi views as "halfbaked ideas approximating 'National Bolshevism." The destructiveness of $\mathrm{Nazi}$ views was also discomforting:

The clearest thing about their plans is the negative aspect -- the idea of breaking down everything and then building it up differently -- an attractive program for dissatisfied people. (38)

A few months later, Ambassador Frederic Sackett expressed the same sense of exasperation regarding the lack of a coherent Nazi program. Hitler's ideas on foreign policy and domestic finance were by no means as clear as the thoughts he had expressed regarding propaganda in Mein Kampf, and therefore, Sackett noted, "they are all the more elusive and difficult to combat.

During his tenure in Berlin, Ambassador Sackett had become an ardent supporter of Dr. Heinrich Brüning, German Chancellor from 1930 to 1932. Sackett admitted having "a rather intimate acquaintance" with Brüning, and made serious efforts to save his embattled government. As Sackett observed, Brüning's "detached air, coolness, evident steadiness of purpose and attention to detail" were 
adnirable qualities resembling those of President Hoover himself, but did not "catch the fancy of the masses."

(40)

Among Brüning's objectives were the abolition of reparations and the resumption of Germany's pre-1914 place in the European power structure. These goals were certainly in keeping with German public opinion, but Brüning's lack of charisma and "austere appeals for sacrifices" could not capture the imagination of the German people as Hitler was doing during the same period.

In December 1930, Sackett wrote a long personal letter to President Hoover regarding the problems of the Brüning government. In it he stressed the instability of Germany's financial status and the beleaguered situation of Brüning's government. Sackett, "perhaps being led by Brúning," also proposed an economic conference under Hoover's leadership. In one historian's view,

It is apparent that Brüning wanted Americans to take the lead not only in the reparations problem, but in revision of the Versailles treaty, and offered nothing in return but his own continuation in power. (42)

In this letter to Hoover, Sackett discounted the importance of the Nazis, whose astonishing election victory in September had just increased their Reichstag representation from 12 to 107 members. Instead, he emphasized Brüning's fear of "the Communistic menace, linked up as it is in each country with the directing heads in Russia." He also insisted that Brúning's views 
represented "the country's responsible thought," and therefore deserved attention.

From the length and alarmist tone of Sackett's letter, it appears that he was attempting to get Hoover's attention and support for Brüning's goals. In this context, the Communists may have been a better attention-getter than the Nazis, whose unclear goals and "deliberate irrationality" offered American observers little more than a sense of confusion. (44) In any case, it was an unusual change of views for Sackett, who had previously dismissed the activities of the German Communists as "puerile."

Through Sackett, the Brüning government continued to pressure for an economic conference to deal with international economic problems. Sackett openly admitted to Sir Horace Rumbold, the British Ambassador in Berlin, that he had suggested the conference in order to help the Brining government, and asked the British to do the same. Rumbold was willing to help, as both nations admired Brüning's stable leadership and feared all the possible alternatives to his government.

As the Depression intensified and further financial crises developed, the conference came closer to becoming a reality. In March 1931, Germany had attempted to improve its economy by creating a customs union with Austria in violation of the Versailles Treaty, which prohibited any kind of Anschluss (union) of Germany and Austria. Foreign 
(particularly French) credits were removed from Austrian banks, and the Creditanstalt, the most important Austrian bank, collapsed in May 1931. Its fall was followed by a flight of capital from Germany, leading to further catastrophe and austerity.

These events were discussed at Chequers, the Prime Minister's country residence near London, in June of 1931, and the conference was an important event in the progression leading to President Hoover's announcement of a one-year moratorium on the payment of reparation and war debts. In the period before the moratorium was declared, German diplomats did their best to convince the Americans that the Nazis, or worse yet the Communists, could take power if American inaction continued. At the Chequers Conference, the German Foreign Minister, Dr. Julius Curtius, said a change of government might bring in the "Hitlerites" or the Communists. The Nazis, as "untried men in office," might "disrupt the Reich and prepare the way for communism." (48) John Motley Morehead, the American minister in Sweden, was visited by the German minister, who informed him of the gravity of the German situation and said the nation would be "driven to Bolshevism before the end of the year" if Hoover's moratorium were not accepted. by Germany's creditors.

Indeed, Ray Atherton, the American charge' d'affaires in London, had been correct when he predicted the Germans 
would use the Chequers conference as a chance to "raise the bogey of a Germany torn on the one hand by Hitlerism and on the other by Bolshevism." (50)

As economic conditions continued in a slump, the fears remained, and the British and the Americans tried to go easy on Germany. Reflecting some months later on the need for the moratorium, Secretary of State Stimson observed that Germany was "a good risk" because of "the character of her population, their technical skill, and their industry . . ." Moreover, Germany was crucial to world financial stability and the containment of communism:

In her position in the center of Europe, Germany in good health would be a bulwark of strength against instability and communism, while if she were allowed to fall the disaster would not be confined to her, but would certainly involve other nations and would greatly affect the financial systems of all the principal nations of the world including our own. (51)

The worst fear of all, repudiation of debts, was discussed in a British memorandum of November 1931 regarding German

finances :

It should not be forgotten that if Germany is subjected to pressure which she considers intolerable, she will, in all probability, declare a moratorium for the whole of her foreign indebtedness and, while negotiations with her creditors are proceeding, will fall back upon the U.S.S.R. as a basis for raw material supply in exchange for industrial equipment. The dangers inherent in such a position, although it would not be a welcome one to Germany, are evident. (52)

In the same memorandum, the British embassy's Berlin 
financial advisor predicted as many others had that the Nazis would be "tamed" and would soon be part of the government, whereas the parties of the left remained a threat to financial stability:

Despite occasional outbreaks of flamboyance, he [Hitler] and his supporters will probably not prove particularly intransigent once they are in the Government. . . . Perhaps the greatest danger is that the Social Democrats and the Communists, who are gaining ground, might be driven to form a common front against the "Fascist menace," which might result in a political deadlock. Such a deadlock, or a really serious Communist gain, of which there is no sign at present, would obviously minimise the chances of an economic recovery and of an acceptable settlement of Germany's public and private foreign debts.

Like most others, these British observers had been taken in by Hitler's facade of "legalism," which would play an ever greater role in 1932, the last year of the Weimar Republic. By May 1932, Chancellor Brilning had been removed from office thanks to the political machinations of General Kurt von Schleicher and others who believed the Nazis could be "tamed." Brüning was replaced by Franz von Papen, then Schleicher himself, and eventually Hitler at the end of January 1933.

Within a few months after taking over as Chancellor, Hitler crushed all other parties and made the Reichstag irrelevant. The precedent for this had been set long before, however, by the Brüning government itself, which had created a system of government by emergency degree. 
Ambassador Sackett reported to the State Department that "a complete transition to government by dictatorship" could occur without destroying the country, whose "banking, commerce and industry are already accustomed to function under a semi-dictatorial government." (54) This system absolved the political parties from responsibility for cooperation, but also offered a convenient pretext for the Nazis to move into the government and continue ruling through nonparliamentary, means.

While the baffling Nazi political platform became no more clear during 1932, the ascendancy of the party made it clear that they, and not the Communists, were to be the main force opposing the crumbling Bruning government and its equally impotent successors. Observers struggled valiantly to try to figure out what sort of role the Nazis would assume after years of complete opposition to the German quo. As Sir Horace Rumbold had observed a year. before, "A party of negation, which advocates the tearing up of treaties and the repudiation of international obligations, cannot exist for an indefinite period."

The Americans and British diplomats were still alarmed about what they perceived as the "radical" Strasser and Goebbels wing of the Nazi party, which still appeared prominent. Sir Horace Rumbold noted in June 1932 that "There is little doubt that Goebbels, if he can pluck up the courage, will yet be a thorn in Hitler's side." 
In October, the British embassy in Berlin reported back to London about a pamphlet with a preface by Gregor Strasser, which was full of socialist ideas resembling "national bolshevism."

In early 1932, Brüning suggested to Ambassador Sackett that he might let the Nazis take the reins of power temporarily, if only to show the world their irresponsibility and lack of leadership ability. This was apparently another of Brüning's efforts to scare the Americans into helping him retain his position. While he made a point of openly rejecting the idea almost as soon as he proposed it, he had a bargaining chip in the Nazi party, since he could point to the two apparent factions within the party: the Hitler wing, then pursuing tactics of apparent "legalism," seemed fairly conservative, but the wing of Goebbels and Strasser was much more radical, and could ally itself with the communists, creating a group "strong enough to plunge the country into a national Communism of a disastrous type." Sackett reported back to the State Department that communism had been invoked "as a cry of wolf" too many times to be taken seriously, but insisted that if a responsible leader like Brüning feared it, there must be a good reason.

In their fear of the Strasser and Goebbels "Socialistic" wing of the party, a threat which never really materialized, the diplomats were possibly deceived 
by one of Hitler's main principles of leadership, the idea of "rival authorities." (60) Hitler made sure the Nazi party was flexible enough to appeal to all interests, and offered propaganda to appeal to all sectors, including of course those on the far left of the political spectrum, but he also made certain that his subordinates were unable to build any power base of their own. He did this by allowing redundant authorities to do the same thing in different places or circumstances, which appears to be what was going on in this case with Strasser and Goebbels -- both were working on propaganda and appealing to leftist sentiments, making Hitler appear more of a reasonable "legalist" by comparison.

Another fear Sackett hinted at was one that had a precedent under Bolshevism -- the possible repudiation of debts (or, in this case, reparations):

If the Bruning Government accepts liability for future reparation payments . . . irrespective of how far such payments are scaled down, the National Opposition [Nazi Party] seems actually ready to precipitate the "threatened" crises and to repudiate reparation payments. It is moreover allegedly willing to accept all consequences. (61)

Sackett achieved little success in alerting the American leadership to the many dangers besetting Brüning. However, his fears regarding the repudiation of reparation payments did prove correct. The Lausanne Conference in the summer of 1932 scaled German reparations down to a minimum. Other 
developments, including the Nazi takeover in 1933, intervened to create a situation in which both reparations and war debt payments had collapsed forever by 1934. As Dexter Perkins has noted:

The essence of the matter is that here was a problem that the diplomats simply could not settle, one in which the prejudices and resistances of the masses were more powerful than any appeal to intelligence could be. And outside the gesture of the Hoover moratorium . . American statesmanship in the last years of the debt question was never ready to face up to explaining to the American people the cold realities of the situation.

The British and American diplomats had discounted Hitler as a man who could not attain the heights of a Mussolini, yet timing, along with a sense of how to use chaos to advantage, was the key to his rise to the chancellorship and his shocking abuses of power once he took office. Sir Horace Rumbold seemingly understood this situation in 1928, when he spoke presciently of the paramilitary Stahlhelm group's limited chances of overthrowing the government, but noted the real possibility of an authoritarian takeover should circumstances change:

The fascist movement in Italy, and the directorate movement in Spain, were rendered possible (a) by a pre-existing condition of social and political disintegration, (b) by the absence of any organized opposition. Neither of these two conditions is present in Germany, and it would require some serious and improbable accident to the political machine to create the circumstances necessary for any "march on Berlin." It is, of course, always possible that if the Stahlhelm leaders feel they are losing ground they might be so foolish as to 
attempt a coup de main. But so long as Germany remains economically, socially and politically as sound as she is to-day, there is no chance of any such Putsch being successful. (63)

Within five years, the "serious and improbable accident" occurred in the form of the Great Depression and the increasing weakness of the republican political system. The unlikely Putsch he described was no longer necessary to those who would find a way to take over the government legally. 


\section{ENDNOTES}

(1) The quotation is from American Agent General for Reparations S. Parker Gilbert, quoted in Villard, Prophets True and Ealse, 24.

(2) Stimson, On Active Service, 196; Schlesinger, The Crisis of the 0ld Order, 242-3 See also Jordan A. Schwarz, The Interregnum of Despair: Hoover, Congress, and the Depression (Urbana, I11., 1970), 45, 50-51.

(3) David Burner, Herbert Hoover: A Bublic Life (New York, 1979), 285; Stimson, Dn Active Service, 197, 191, 200. 8.

(4) Schwarz, The Interregnum of Despair, 11-12, 232-

(5) Ibid., 48; Stimson, On Active Service, 196.

(6) Hodgson, The Colonel, 5-6, 20, 173, 23, 29, 140.

(7) Ibid., 14, 16-7.

(8) Ibid., 173-5, 29, 171.

(9) E. Wilder Spaulding, Ambassadors Ordinary and Extraordinary (Washington, D.C., 1961), 8.

(10) Ibid., 11, 13. Memoirs by diplomats and their wives frequently decried the difficulties of maintaining a diplomatic residence on State Department pay. Maude Parker Child (wife of Mussolini's admirer, Ambassador Richard Washburn Child), noted that the Romans expected to be entertained on a grand scale by the Americans as well as the British, a difficult proposition when the American Ambassador was paid $1 / 3$ of the British Ambassador's allowance. See Maude Parker Child, The Social Side of Diplomatic Life (Indianapolis, 1924), 24, 37.

(11) Villard, Rrophets True and Ealse, 24.

(12) Lewis Einstein, A Diplomat Looks Back (New Haven, 1968), xv, xxvii, 207. For a dissenting view, see Ray Lyman Wilbur and Arthur Mastick Hyde, The Hoover Policies (New York, 1937), 585-6, which contends that 
Hoover strengthened the position of the career men in the State Department.

(13) Bernard V. Burke, "Senator and Diplomat: The Public Career of Frederic M. Sackett," The Eilson Club History Quarterly, 61:2 (April 1987), 195-8.

\section{(14) Spaulding, Ambassadors Ordinary and} Extraordinary, 146-8. See also William Castle to Herbert Hoover, January 21, 1929, William Castle Papers, Harvard University Library, in which Castle criticizes Schurman as a "careless speaker" and too pro-German, and suggests replacing him with a businessman rather than another intellectual.

(15) Burke, "Senator and Diplomat," 207.

(16) William E. Dodd, Jr. and Martha Dodd, eds., Ambassador Dodd's Diary: 1933-1938 (New York, 1941), 16. Martha Dodd gives a similar characterization of Gordon in her memoir, Throush Embassy Eyes (Garden City, N.Y., 1940), 20-21, though she does not mention his name.

(17) On Gordon's notorious temper, see George S. Messersmith, "Some observations on the appointment of $\mathrm{Dr}$. William Dodd," George S. Messersmith Papers, University of Delaware Library, 4, 8, 10 . Gordon was an aristocrat and friend of such high-ranking diplomats as Jay Pierrepont Moffat - - see Gordon to Moffat, December 15, 1932, and Gordon to Moffat, March 13, 1933, Jay Pierrepont Moffat Papers, Harvard University, in which Gordon begs Moffat for Washington gossip. On Gordon's lack of contact with opposition groups, see Moffat to Castle, August 10, 1932, Moffat Papers, Harvard University.

(18) Some of the historical controversies regarding the origins of Fascism and Nazism are explored in Gilbert Allardyce, "What Fascism is Not: Thoughts on the Deflation of a Concept," with comments by Stanley G. Payne and Ernst Nolte and reply by Gilbert Allardyce, American Historical Review 84:2 (April 1979), 367-98. For more historiographical discussions of the many baffling varieties of Fascism, see Juan J. Linz, "Some Notes Toward a Comparative Study of Fascism in Sociological Historical Perspective" in Walter Laqueur, ed., Eascism: A Reader's Guide (Berkeley, 1976), 3-121; Michael Burleigh and Wolfgang Wippermann, The Racial State: Germany, 1933-1945 (Cambridge, 1991), 7-22; and Stanley G. Payne, Eascism: Comparison and Definition (Madison, 1980).

(19) Fest, Hitler, 125, 157, 177, 192; Mack Smith, 
Mussolini, 172-3; Mack Smith, Mussolini's Roman Empire, 223.

\section{(20) Paul Kosok, Modern Germany, A Study of} Conflicting Loyalties (Chicago, 1933), xv. Throughout the book the Nazis are referred to as Fascists, being called "Nazis" in quotation marks only. Villard, Prophets True and Ealse, refers to the Nazis in 1928 as the "German Fascisti." One of the earlier mentions of the Nazis by an American diplomat is Ambassador Schurman's introduction of them as the "National Socialists or Fascists." See Schurman to State, December 5, 1929, Papers of the Department of State, deposited in the National Archives, Decimal File 862.00/2473. All State Dept. Papers hereafter cited as "SDP" with Decimal File number.

(21) See Anonymous, "Hitler, Germany's Would-be Mussolini," Literary Digest 107 (October 11, 1930), 15-16; also cartoon by Hungerford reprinted from the Pittsburgh Rost-Gazette, ibid., 14, showing Hitler as a Chaplinesque "little tramp" following barrel-chested circus acrobat Mussolini across a tightrope.

(22) Pierre L. de Boal (Chief of the Division of Western European Affairs) to Sackett (the Ambassador in Germany), December 8, 1931, and Enclosure (Memorandum Prepared in the Department of State) by Herbert Feis, ERUS $1932 \quad 2: 276$.

(23) Sackett to Boal, July 12, 1932, Enclosure (Memorandum by the American Embassy), ibid., 279.

(24) Mack Smith, Mussolini, 118-20 and 189-90, discusses the extent to which the much-discussed Italian "corporate state" was largely a fiction.

(25) Boal to State, June 4, 1932, ERUS 1932 2:296.

(26) On Hitler's early view of himself as the "drummer" for German nationalism, see Fest, The Eace of the Third Reich, 23, 26, 31 .

(27) Paul Scheffer, "Hitler: Phenomenon and Portent." Eoreign Affairs 10:3 (April 1932), 383; Ludwig, Talks With Mussolini, 6 . On Mussolini's lack of a concrete program (at least until he decided to have someone write one for him in the late 1920s) see Mack Smith, Mussolini, $48,138-43$.

(28) Fest, The Eace of the Third Reich, 32. 
(29) Ibid., 26, 33, 40-1.

(30) Sir Ronald Lindsay (Ambassador at Berlin) to Sir Austen Chamberlain (Foreign Minister), May 3, 1928, \#17, DBEP $1 A: 5,29$.

(31) See Orme Sargent (Foreign Office) to Sir Ronald Lindsay, May 29, 1928, \#41, DBEE 1A:5, 76.

(32) Mr. William Seeds to Chamberlain, May 2, 1929, \#151, DBEP $1 \mathrm{~A}: 6,305$.

(33) Ibid., minutes from Central Department of the Foreign Office.

(34) Nicolson to Henderson, November 20, 1929, \#87, DBEP $1 A: 7,168-9$.

(35) Ibid.; Nicolson to Henderson, December 4, 1929, $\# 109$, DBEP $1 \mathrm{~A}: 7,222$.

(36) Rumbold to Henderson, December 17, 1929, \#14, DBEP 1A:7, 261.

$3: 77-9$.

(37) Gordon to State, September 17, 1930, ERUS 1930,

(38) Gordon to State, April 8, 1931, SDP 862.00/2588; Gordon to State, October 7, 1930, SDP $862.00 / 2549$. $86.00 / 2573$.

(39) Sackett to Stimson, December 17, 1930, SDP

(40) Sackett to Hoover, December 27, 1930, Herbert Hoover Presidential Library Papers, West Branch, Iowa, under Foreign Affairs -- Diplomats (Sackett, Frederic M.) -Hereafter referred to as HHPL; Sackett to Stimson, December 17, 1930, SDP 862.00/2513.

(41) Hajo Holborn, A History of Modern Germany: 18401945 (Princeton, 1969), 666-7.

(42) Burke, "American Economic Diplomacy," 227.

(43) Sackett to Hoover, December 27, 1930, HHPL Papers, Foreign Affairs -- Diplomats (Sackett, Frederic M.)

(44) Selig Adler, The Uncertain Giant: 1921-1941. American Eoreign Bolicy Between the Wars (New York, 1965), 137-8. 
(45) Sackett to State, March 22, 1930, SDP $862.00 / 2492$.

(46) Henderson to Rumbold, February 19, 1931, \#350, DBFP 2:1, 559-60; Rumbold to Henderson, March 4, 1931, \#353, DBEP 2:1, 577-8; Rumbold to Henderson, March 6, 1931, \#354, DBEP 2:1, 580-01; Enclosure -- note by Sir. R.

Vansittart in Henderson to Sir W. Erskine (Warsaw), June 6 , 1931 , \#48, DBEP $2: 2,69$.

(47) E. L. Woodward, "Preface," DBEP 2:2, iii-v.

(48) Atherton (American charge' d'affaires in London) to State, June 8, 1931, SDP $462.00 \mathrm{R} 2961 / 3954$.

(49) Telegram, Morehead to State, June 22, 1931, SDP 462.00 R296/4029.

(50) Atherton to State, June 5, 1931, SDP NA 500.A15 $\mathrm{A} 4 / 219$.

(51) Stimsen Diaries, XI, 118 (microfilm reel 2).

(52) "Germany's Economic and Financial Situation in Relation to her Foreign Indebtedness," Enclosure in B.C. Newton (Berlin) to Sir J. Simon, November 20, 1931, \#301, DBEP $2: 2,344$.

(53) Ibid., 345.

(54) Sackett to Pierre L. de Boal (Chief of Division of Western European Affairs), January 12, 1932, ERUS 1932 $2: 279-80$.

(55) Karl Dietrich Bracher, The German Dictatorship (New York, 1970), 171.

(56) Rumbold to Henderson, January 16, 1931, \#346, DBEP $2: 1,551$.

4.

(57) Rumbold to Simon, June 28, 1932, \#2, DBEP 2:4,

(58) Newton to Simon, October 13, 1932, \#29, DBFP $2: 4,60-1$.

(59) Sackett to Stimson (Personal), January 12, 1932, SDP 462.00 R296 A $1 / 150$.

(60) On Hitler's "divide and conquer" leadership, see Fest, Hitler, 247,674-5, and Bullock, Hitler, 381 . 
(61) Sackett to Stimson, January 12, 1932, HHPL papers, Presidential Foreign Affairs - Financial.

(62) Dexter Perkins, "The Department of State and American Public Opinion," in Gordon A. Craig and Felix Gilbert, The Diplomats: 1919-1939 (Princeton, 1953), 307.

(63) Rumbold to Sargent, November $30,1928, \# 250$, DBEP $1 \mathrm{~A}: 5,505$. 
CHAPTER VI

BOLSHEVISM, FASCISM AND NAZISM - CONCLUSIONS

In the years since World War II, it has become customary to speak of Fascism as a movement of very similar right-wing ideologies that swept over Europe between the two World Wars. There were Fascist regimes in Italy, Turkey, Poland, Austria, and Spain, but the most notorious of all the Fascists were the National Socialists or Nazis of Germany, who represented "the most radical, the most absolute manifestation of Fascism."

Today the word "Fascism" is often misused, and there is a tendency by some to see Fascism as a monolithic movement or apply the label to any authoritarian right-wing anti-communist group. However, even now, nearly 70 years after this ideology rose to prominence with Mussolini's March on Rome, "the essence of Fascism remains elusive." (2)

One aspect of Fascism that must be considered is its genesis as an anti-Communist movement and its latent similarities with Communism. Ernst Nolte, a leading interpreter of Fascism, has defined the ideology as follows: 
Fascism is anti-Marxism which seeks to destroy the enemy by the evolvement of a radically opposed and yet related ideology and by the use of almost identical and yet typically modified methods, always, however, within the unyielding framework of national self-assertion and autonomy.

This definition implies that without Marxism there is no fascism, that fascism is at the same time closer to and further from communism than is liberal anti-communism, that it necessarily shows at least an inclination toward a radical ideology, that fascism should never be said to exist in the absence of at least the rudiments of an organization and propaganda comparable to those of Marxism.

American and British diplomats in interwar Europe were as perplexed as anyone today when trying to interpret the varieties of Fascism, but in the early 1930 s they were more attuned to the differences than to the similarities between the two most important Fascist movements, those of Italy and Germany. There were legitimate reasons to see the two as dissimilar, and this tendency was reinforced by the fact that "Fascism differed within each country that fell victim to its baneful influence." If the Nazis can be considered the most radical of the Fascist movements, it can also be argued that Mussolini's Italy was "less fascist" than other regimes that followed, since it never reached its professed level of total control over all aspects of Italian society. (4) Yet as the first of the Fascist national leaders and as a model for whom Hitler declared his admiration, it would seem that Mussolini and his regime offered the logical analogy for diplomats reporting on the 
rise of the Nazis.

Within a month of Hitler's ascent to the chancellorship, the parallels between the two regimes were obvious to at least one American diplomatic observer, Leon Dominian, the Consul General in Stuttgart. Dominian had served previously in Rome and immediately recognized similarities with Italian Fascism in the wholesale replacement of government officials with loyal Nazis, the curtailment of the press, and the suppression of opposition parties.

The Nazis, of course, went far beyond the Italian Fascists in their aggressiveness, swift takeover of the government, and excessive uses of power. In the early period of Hitler's rule, the Italians were still able to impress the American diplomats with their image as the more reasonable senior partner of the two Fascist regimes. They were much more concerned with worldwide public opinion, and thus their behavior offered quite a contrast with that of Hitler in November 1933 when Germany withdrew from the League of Nations and the Disarmament Conference. Consul General George Messersmith in Berlin, one of the more perceptive diplomatic observers of the Nazis, reported two incidents in which the Italian Ambassador, while trying to convince Hitler of the importance of remaining within these international organizations, was rewarded with extreme outbursts on Hitler's part: 
He [Hitler] has been deeply hurt in his personal pride. . by the unfavorable comparisons which are being made between him and Mussolini and between German National Socialism and Italian Fascism. It is known, for instance, that in a recent interview which he had with the Italian Ambassador when the Ambassador gave him certain messages on behalf of Mussolini indicating particularly that Italy feared the extravagant and radical measures of National Socialism in Germany and the consequences of her withdrawal from the League and the Disarmament Conference, the Chancellor went into one of his frenzies and is said to have actually wept, stating that Mussolini had abandoned him because he was jealous of the place that German National Socialism was getting in the world and that after all, although Fascism had done a great deal for Italy, it was German National Socialism which was beginning to be the salvation not only of its country, but of the world.

A few days later, Messersmith reported another similar account of a Hitler outburst when the Italian Ambassador informed him that German withdrawal from the League and the Disarmament Conference "would be looked upon with the greatest regret and concern by the Italian Government." The account of the first tantrum is attributed to "a most reliable source," and the second, while not from the Italian Ambassador, is "from a practically first hand and unimpeachable source." (7) The Italian Ambassador came out of the situation appearing by far the more reasonable of the two parties, and the Italians again succeeded in dissociating themselves from Hitler's worst excesses.

These outbursts from Hitler are indicative of his growing independence and also his increasing rivalry with Mussolini for preeminence as a Fascist leader. However, 
the Italians still held to their view of themselves as custodians of the international image of Fascism. In November 1933, the Italian Ambassador showed a sensitivity to public opinion regarding the increasing harassment and propaganda against women who smoked and used cosmetics:

The movement was gaining such ground and arousing such ridicule that, as I learned from a well informed source, the Italian Ambassador brought the matter to the attention of Mr. Hitler, saying that these absurd manifestations of the National-Socialist movement in Germany were bringing Fascism into ridicule before the world and that ridicule was a dangerous weapon.

As late as 1934 , Italy was still counted by Messersmith among the European powers that could be reasoned with, and could help reason with the Germans if necessary. In an April 1934 letter to William Phillips, he expressed hopes for the possible fall of Nazism and suggested possible outcomes:

When the moment for action comes in Germany and when there is a change of regime here, I think we at home, England, France and Italy will have to make it clear to the German people that with their new Government we will be in a position to, and will be prepared to deal in a new way and help in the settlement of their economic and political problems. (9)

One question that recurs for the observer of diplomatic reactions to Hitler's rise to power is that of why American and British diplomats would find the analogy of Bolshevism so much more tempting than that of Italian Fascism, at least in the beginning. Of course, one must take into account the way in which Hitler and Mussolini have become 
inextricably linked in our postwar minds as the Fascist Axis powers of World War II -- a connection which obviously did not exist in the minds of observers in the early 1930s. Nevertheless, a survey of press accounts of the times shows that journalistic observers in America frequently viewed Hitler as a potential "new Mussolini" and definitely saw parallels between his leadership style and that of II Duce, parallels which seemed less noticeable to Anglo-American diplomats serving in Germany at the time.

The concept of totalitarianism can be helpful in our understanding of the diplomatic viewpoint. The notion of totalitarianism did not become widely used in America until the late 1930s, but the diplomats in Berlin, while lacking the word itself, seemed to understand instinctively that what they were dealing with was a new phenomenon qualitatively different from the Fascism of Mussolini. National Socialism was indeed "a unique and radical kind of modern revolutionism," though its revolutionary nature was largely destructive. And seen within a framework of totalitarianism, Nazism did bear more resemblance to Soviet Bolshevism than to Italian Fascism:

For much of the generation after the war, the concept of totalitarianism held vogue, likening Nazi Germany to the Soviet Union, however, much more than to Italy. The definition of totalitarianism has always been remarkably vague, and the most recent fad has been to deny that any such thing existed or exists. Since theorists of totalitarianism rarely get beyond such rudimentary and limited 
qualities as the single party, the use of terror, and mass mobilization, it is easy to argue either that many different kinds of regimes are totalitarian or conversely that none of them is perfectly total.

Yet the concept of totalitarianism is both valid and useful if defined in the precise and literal sense of a state system that attempts to exercise total control over all significant aspects of all major national institutions, from the economy and armed forces to the judicial system, the churches, and culture. It has been seen that in this sense the Mussolini regime was not totalitarian at all, and the Hitler system also failed to achieve full totalitarianism, though in its final phase it drew nearer and nearer. (11)

Stanley Payne, a leading observer of Fascism, has noted the important ways in which Hitlerism differed from Mussolini's original Fascist ideology. Hitler based his ideology on race, while Mussolini's was founded on political and cultural nationalism. Hitler's one-man state differed greatly from Mussolini's "juridical state of semipluralism and formal law." The Nazi party played a far larger role in Germany than did the Fascist party in Italy. Nazism's violent anti-Semitism was a marked change from Italian Fascism's conventional early twentieth-century racism. Lastly, Mussolini's imperial designs never went beyond those of "traditional Italian nationalist/imperialist policy," while Hitler's foreign policy ultimately went beyond the old goals of German expansionism in an attempt at revolutionary restructuring of Europe itself.

In succumbing to the temptation to see Nazism as a 
phenomenon akin to Bolshevism, the diplomats may not have been entirely incorrect. In the same chapter where he noted the dissimilarities between Nazism and Italian Fascism, Payne observed the following similarities between Nazism and Russian Communism:

1. Frequent recognition by Hitler and various Nazi leaders (and also Mussolini) that their only revolutionary and ideological counterparts were to be found in Soviet Russia

2. The founding of both National Socialism and Russian national communism on a revolutionary action theory which held that success in practice validated ideological innovation, as the Soviet Union progressively relinguished main aspects of classic Marxist theory

3. Revolutionary doctrines of "constant struggle"

4. Rigid elitism and the leadership principle: National Socialist was someone who followed Hitler; a Bolshevik was not necessarily a Marxist but someone who followed Len in

5. Espousal of the have-not, proletarian -nation theory, which Lenin adopted only after it had been introduced in Italy

6. Construction of a one-party dictatorship independent of any particular class

7. Major stress, not merely on a political militia (which was increasingly common in the late nineteenth and early twentieth centuries), but upon a party-army, with a regular army to be controlled by the party. . . .

8. Emphasis on autarchy and major (not merely partial) militarization. . promotion of revolutionary war whenever possible as an alternative to complete and balanced internal development

9. An NEP phase of partial pluralism on the road to more complete dictatorship.

10. International projection of a new ideological myth as an alternative to prevailing orthodoxies, capable of eliciting a not-insignificant international response; variants of Fascist and 
Nazi ideologies constituted the last notable ideological innovations in the modern world after Marxism (13)

Along with the genuinely revolutionary nature of Nazism and its very real parallels to Bolshevism, there are other factors to consider. Among these was the "Bolshevism bogey" so beloved of Stresemann and other Weimar leaders. In their struggle to gain foreign support, acceptance, and funds for the existing regime, they found it convenient to remind their benefactors of an enemy within, a dangerous, out-of-control political movement that could crush the existing system which, whatever its disadvantages, was at least nominally republican and provided a good atmosphere for international investment. The idea of a group of Fascists imitating Mussolini in Germany could hardly strike fear into the hearts of the British and the Americans, for Mussolini himself had also provided a good atmosphere for international investment.

But the notion of the triumph of Bolshevism was another matter. The Bolsheviks were destroyers of capitalist economies, repudiators of debts, and sworn enemies of the business ideology and the status quo that the British and Americans openly espoused. As an attention-getter, the notion of so-called Fascists financed by Communists, or of wantonly destructive Nazis destroying Weimar society in time for the Communists to start their new regime on its ashes, was far more persuasive than the 
thought of another dictatorial Fascist regime arising, which would be morally repellent, perhaps, but not necessarily a source of economic chaos.

It was, above all, their uniformly hostile reaction to Bolshevism and their largely favorable reaction to Italian Fascism that ensured that, at least for a while, American and British diplomats would interpret early Nazi uprisings in terms of Communist or quasi-Communist action, rather than seeing Nazism as a very dangerous and revolutionary variant of Italian Fascism. Interestingly, the concept of "Red Fascism" took hold again in the post-World War II era of the early Cold War:

Americans both before and after the Second World War casually and deliberately articulated distorted similarities between Nazi and Communist ideologies, German and Soviet foreign policies, authoritarian controls, and trade practices, and Hitler and Stalin. This popular analogy was a potent and pervasive notion that significantly shaped American perception of world events in the cold war. Once Russia was designated the "enemy" by American leaders, Americans transferred their hatred for Hitler's Germany to Stalin's Russia with considerable ease and persuasion.

Anti-Communism, as the leading feature of American foreign policy throughout most of the twentieth century, was bound to have an enormous effect on American diplomats observing the rise of Nazism, a philosophy so willfully confusing that it still baffles observers nearly forty years after its demise. If American and British diplomats sometimes saw Bolsheviks in Germany instead of Nazis, this 
had much to do with the distorted conditions of public life in Germany in the early 1930s. Sir Horace Rumbold said it best in 1931:

In attempting to appreciate possible developments in Germany under such conditions of strain one must remember that the situation can alter very rapidly. Elements which assume temporary importance may disappear, while others, not apparent to a superficial observer, may prove to have enduring value; and no analysis can hope to retain its validity for more than a comparatively limited period. (15)

Given their existing fears and prejudices and the turbulent land of confusion and shadows that was Germany in the early 1930s, American and British diplomats produced analyses as good as any that could be expected. Although they may have underestimated the dangers of Fascist ideology in Italy, they grasped the deeply revolutionary and destructive nature of National Socialism and thus described it frequently in terms of their only available synonym for revolution and destruction -- Russian Bolshevism. 


\section{ENDNOTES}

(1) Fest, Hitler, 376 .

(2) Hugh Seton-Watson, "Fascism, Right and Left," Journal of Contemporary History $1: 1$ (1966), 183. $1966), 20-1$.

(3) Ernst Nolte, Three Eaces of Eascism (New York,

(4) Selig Adler, The Uncertain Giant: 1921-1941, American Eoreign Bolicy Between the Wars (New York, 1965), 138; Seton-Watson, "Fascism, Right and Left," 192.

(5) Leon Dominian to State, February 21, 1933, ERUS 1933. 2:193-198 passim.

(6) George Messersmith to State, November 1, 1933, \#1696, Messersmith MSS, University of Delaware Library, Newark, Del.

(7) Messersmith to State, November 3, 1933, Messersmith MSS.

(8) Messersmith to State, November 17, 1933, \#1747, Messersmith MSS.

(9) Messersmith to William Phillips, April 27, 1934, Messersmith MSS.

(10) Stanley G. Payne, Eascism: Comparison and Definition (Madison, 1980), 99.

(11) Ibid., 95-96.

(12) Ibid., 101-2.

(13) Ibid., 102-4.

(14) Les R. Adler and Thomas G. Paterson, "Red Fascism: The Merger of Nazi Germany and Soviet Russia in the American Image of Totalitarianism, 1930's-1950's," American Historical Review 75:4 (April 1970), 1046.

(15) Rumbold to Henderson, March 4, 1931, \#353, DBEP $2: 1,573$. 
Papers and Unpublished Sources: **

William R. Castle Papers, Herbert Hoover Presidential Library, West Branch, Iowa.

Herbert Hoover Presidential Papers, Herbert Hoover Presidential Library, West Branch, Iowa.

Jay Pierrepont Moffat Papers, Harvard University.

George S. Messersmith Papers, University of Delaware Library, Dover, Delaware.

Papers Relating to the Eoreign Relations of the United States, 1920-1933. Washington, U.S. Government Printing office.

Records of the Department of State Relating to Rolitical Relations Between the United States and Italy. 1910-29. National Archives Microfilm Publications $\# 529$.

State, Department of. Papers of the U.S. Department of State, National Archives, Washington, decimal files 862.00 (Internal Affairs, Germany), 462.00/R296 and 123, Sackett, FM.

Stimson, Henry L. Diaries of Henry Lewis Stimson. Microfilm Edition. New Haven: Yale Univ. Library, 1973.

Stimson, Henry L. Papers of Henry Lewis Stimson. Microfilm Edition. New Haven: Yale Univ. Library, 1973.

Woodward, E.L. and Rohan Butler, eds. Documents on British Eoreign Policy, 1919-1939, Series I, IA, and II. London: His Majesty's Stationery Office.

** Unless otherwise noted, photocopies of all unpublished manuscript materials are in the possession of Dr. Bernard V. Burke, Portland State University History Department. 
Articles (Primary Source Material):

Anonymous. "Dangerous Days in Europe." Literary Digest, October $25,1930,14-15$.

"Germany's Inflamed Youth." Literary

Digest, November 1, 1930, 16.

"Handsome Adolf, the Man Without a Country."

Literary Digest, October 18, 1930, 34-40.

"Hitler -- Germany's Would-Be Mussolini."

Literary Digest, October 11, 1930, 15-16.

"Hitler's Labor Policies." Business Week, April 19, 1933, 6.

"Hitler's Program is Vague." Business

Week, May 10, 1933, 24-25.

"Mussolini Snaps His Teeth Again." Literary Digest, November 15, 1930, 12-13.

"Mussolini's Road to Imperial Italy."

Literary Digest, June 9, 1923, 18-19.

"Why Mussolini Charms the American Business Man." Literary Digest, June 9, 1923, 72-74.

Carter, John. "America's Present Role in World Affairs." Current History 35:2 (November 1931), 161-166.

Chamberlin, William Henry. "Russia and Germany--Parallels and Contrasts." The Atlantic 156:3 (September 1935), $359-368$.

Comstock, Alzada. "The Inside of Germany's Purse." The Eorum LXIX:3 (March 1923), 1332-1343.

Dennis, Lawrence. "Sold' on Foreign Bonds." The New Republic LXV:833-837 (5 part article); November $19,1930,8-11$; December 3, 1930, 65-68.

Duffield, Marcus. "Mussolini's American Empire: The Fascist Invasion of the United States." Harpers 159 (November 1929), 661-672.

Dulles, John Foster. "Our Foreign Loan Policy." Eereign Affairs 5:1 (October 1926), 33-56. 
Friedrich, Carl Joachim. "Dictatorship in Germany?"

Eoreign Affairs 9:1 (October 1930), 118-132.

Fuchs, James. "Why Matteotti Had to Die." The Nation 119:3082 (July 30, 1924), 114-115.

Geiser, Karl F. "Will Germany Live Again?" The Nation 119:3090 (September 24, 1924), 318-320.

Hoben, Lindsay. "Threats of Revolution." Current Histery 35:3 (December 1931), 387-392.

Laski, Harold. "Lenin and Mussolini." Eoreign Affairs $2: 1$ (September 1923), 43-54.

Motherwel1, Hiram. "Mussolini: Emperor of the Latins?" Harpers 159 (June 1929), 34-49.

Mowrer, Edgar Ansel. "The Fascisti and Italy's Economic Recovery." The Eorum 69:1 (January 1923), 11981207.

158 (December 1928), 61-69.

"Germany After Ten Years." Harper's

"The Rule of the Fascisti." The Eorum 69:3 (March 1923), 1299-1307.

Scheffer, Paul. "Hitler: Phenomenon and Portent." Eoreign Affairs 10:3 (April 1932), 382-390.

Villard, Oswald Garrison. "Mussolini and the Klan." The Nation 119:3078 (July 2, 1924), 5.

Articles (Secendary Source Material):

Adler, Les R., and Paterson, Thomas G. "Red Fascism: The Merger of Nazi Germany and Soviet Russia in the American Totalitarianism, 1930's-1950's." American Historieal Revien 75:4 (April 1970), 1046-1064.

Allardyce, Gilbert. "What Fascism is Not: Thoughts on the Deflation of a Concept," with comments by Stanley G. Payne and Ernst Nolte, reply by Gilbert Allardyce. Ameriean Historical Review 84:2 (April 1979), 367388.

Boller, Paul F., Jr. "The 'Great Conspiracy' of 1933: A Study in Short Memories." Southwest Review 39:2 (Spring 1954), 87-112. 
Burke, Bernard V. "American Economic Diplomacy and the Weimar Republic." Mid-America 54:4 (Oct. 1972), 212233 .

"Senator and Diplomat: The Public Career of Frederic M. Sackett." The Eilson Club History Quarterly, 61:2 (April 1987), 185-216.

Cassels, Alan. "Fascism For Export: Italy and the United States in the Twenties." American Historical Beview 69:3 (April 1964), 707-712.

"Mussolini and German Nationalism, 1922-25." Journal of Modern History 35:2 (June 1963), 137-157.

Current, Richard N. "Henry L. Stimson." In Graebner, Norman A., ed., An Uncertain Tradition: American Secretaries of State in the Twentieth Century (New York, McGraw-Hill, 1961), 168-183.

Dallek, Robert. "Beyond Tradition: The Diplomatic Careers of William E. Dodd and George S. Messersmith, 19331938." The South Atlantic Quarterly 66 (1967), 233244 .

Delzell, Charles F. "Benito Mussolini: A Guide to the Biographical Literature." Journal ef Modern History 35:4 (December 1963), 339-353.

Diggins, John P. "Flirtation With Fascism: American Pragmatic Liberals and Mussolini's Italy." American Historical Review 71:2 (January 1966), 487-506.

Ellis, L. Ethan. "Frank B. Kellogg (1925-1929)." In Norman A. Graebner, ed., An Uncertain Tradition: American Secretaries of State in the Twentieth Century (New York: MoGraw-Hil1, 1961), 141-167.

Erdmann, Andrew P.N. "Mining for the Corporatist Synthesis: Gold in American Foreign Economic Policy, 1931-1936." Diplomatic History 17:2 (Spring 1993), $171-200$.

Ferrell, Robert H. "Henry L. Stimson." In Bemis, Samuel Flagg, ed., The American Secretaries of State and Their Diplomacy, (New York: Cooper Square Publishers, Inc., 1963), vol. 9, 137-279.

Filene, Peter G. "An Obituary for 'The Progressive Movement." American Quarterly 22:1 (Spring 1970), $20-34$. 
Gaddis, John Lewis. "The Corporatist Synthesis: A Skeptical View." Diplomatic Histery 10:4 (Fall 1986), $357-362$.

"New Conceptual Approaches to the Study of American Foreign Relations." Diplomatic History $14: 3$ (Summer 1990), 405-423.

Grant, Natalie. "The Russian Section, A Window on the Soviet Union." Diplomatic History 2:1 (Winter 1978), $107-115$.

Harrington, Daniel F. "Rennan, Bohlen and the Riga Axioms." Diplomatic History 2:4 (Fall 1978), 423-437.

Helbich, Wolfgang $J$. "Between Stresemann and Hitler:

The Foreign Policy of the Brüning Government."

world Rolities 12 (1959), 24-44.

Hogan, Michael J. "Corporatism: A Positive Appraisal." Diplomatic History 10:4 (Fall 1986), 363-372.

"Revival and Reform: America's Twentieth-Century Search for a New Economic Order Abroad." Diplomatic History 8:4 (Fall 1984), 287-310.

Jacobson, Jon. "Is There a New International History of the 1920s?" American Historical Review 88:3 (June 1983), 617-645.

Kolko, Gabriel. "American Business and Germany, 19301941." Western Political Quarterly 15 (December 1962), $713-728$.

Leffler, Melvyn P. "American Policy Making and European Stability, 1921-1933." Racific Historical Review $46: 2$ (1977), 207-228.

"Political Isolationism, Economic

Expansionism, or Diplomatic Realism: American Policy Toward Western Europe, 1921-1933." Eerspectives in American History 8 (1974), 413-461.

Little, Douglas. "Antibolshevism and American Foreign Policy, 1919-1939: The Diplomacy of Self-Delusion." American Quarterly 35 (1983), 376-390.

McCormick, Thomas J. "Something 0ld, Something New: John Lewis Gaddis's "New Conceptual Approaches.

Diplomatic History 14:3 (Summer 1990), 425-432. 
McGovern, James R. "David Graham Phillips and the Virility Impulse of Progressives." The New England Quarterly, $39: 3$ (September 1966), 334-355.

McKercher, Brian. "Reaching for the Brass Ring: The Recent Historiography of Interwar American Foreign Relations." Diplomatic History, 15:4 (Fall 1991), $565-598$.

Maier, Charles S. "The Two Postwar Eras and the Conditions for Stability in Twentieth-Century Western Europe." With Comments by Charles P. Kindleberger and Stephen A. Schuker, and a reply by Charles S. Maier. American Historical Review 86:2 (April 1981), 327-367.

Noether, Emiliana P. "Italy Reviews its Fascist Past: A Bibliographical Essay." American Historical Review 61:4 (July 1956), 877-899.

Offner, Arnold A. "Feature Review: Misperception and Reality: Roosevelt, Hitler, and the Search for a New Order in Europe" (review of Robert E. Herzstein, Roosevelt and Hitler: Rrelude to War). Diplomatic History 15:4 (Fall 1991), 607-619.

Perkins, Dexter. "The Department of State and American Public Opinion." In Craig, Gordon A., and Felix Gilbert, eds., The Diplomats: 1919-1939 (Princeton, N.J.: Princeton Univ. Press, 1953), 282-308.

Propas, Frederic L. "Creating a Hard Line Toward Russia: The Training of State Department Soviet Experts, 19271937." Diplomatic History 8 (1984), 209-226.

Sarti, Roland. "Fascist Modernization in Italy: Traditional or Revolutionary?" American Historical Review 75:4 (April 1970), 1029-1045.

Sauer, Wolfgang. "National Socialism: Totalitarianism or Fascism?" American Historical Review 73:2 (December 1967), 404-424.

Seton-Watson, Hugh. "Fascism, Right and Left." Journal of Contemporary History $1: 1$ (1966), 183-197.

Stromberg, Roland. "American Business and the Approach of War, 1935-1941." Journal of Economic History 13:1 (Winter 1953), 58-78. 
Tannenbaum, Edward R. "The Goals of Italian Fascism." American Historical Review, $74: 4$ (April 1969), 1183-1204.

Van Everen, Brooks. "Franklin D. Roosevelt and the Problem of Nazi Germany." In Clifford I. Egan and Alexander W. Knott, eds., Essays in Twentieth Century American Diplomatic History Dedicated to Rrofessor Daniel $M$. Smith (Washington, D.C.: University Press of America, 1982), 137-158.

Vinson, John Chalmers. "Charles Evans Hughes (1921-1925)." In Norman A. Graebner, ed., An Uncertain Tradition: American Secretaries of State in the Twentieth Century (New York: McGraw-Hill, 1961), 128-148.

Weinberg, Gerhard I. "Hitler's Image of the United States." American Historical Review 69:4 (July 1964), 1006-1021.

Werking, Richard Hume. "Selling the Foreign Service: Bureaucratic Rivalry and Foreign Trade Promotion, 1903-1912." Pacific Historical Review 45 (May 1976), 185-201.

West, Franklin C. "Success Without Influence: Emil Ludwig during the Weimar Years." Rublications of the Lee Breck Institute, Year Boek XXX (1985), 169-189.

Books and Rublished Memoirs:

Adler, Selig. The Uncertain Giant: 1921-1941. American Policy Between the Wars. New York: The MacMillan Co., 1965; paperback ed., Collier Books, 1969.

Aldrich, Nelson W., Jr. Old Money: The Mythology of America's Upper Class. New York: Alfred A. Knopf, 1988 .

Alexander, Charles C. Nationalism in American Thought, 1930-1945. The Rand McNally Series on the History of American Thought and Culture. Chicago: Rand MeNally \& Company, 1969.

Alsop, Joseph W., with Adam Platt. "I've Seen the Best of It:" Memoirs. New York: W.W. Norton \& Co., 1992.

Arendt, Hannah. The Origins of Totalitarianism. New Edition With Added Prefaces. New York: Harvard Brace Jovanovich, 1979. 
Bane, Suda Lorena and Ralph Haswell Lutz, eds. Oreanization of American Relief in Europe, 1918-191. Publication No. 20, Hoover Library on War, Revolution and Peace. Stanford, Ca.: Stanford University Press, 1943.

Baumont, Maurice. The Origins of the Second Werld War. Trans. by Simone De Couvreur Ferguson. New Haven and London: Yale University Press, 1978.

Bennett, Edward M. Eranklin D. Boosevelt and the Search for Security: American-Soviet Relations, 1933-1939. Wilmington, Del.: Scholarly Resources Inc., 1985.

Germany and the Diplomacy of the Einancial Crisis, 1931. Cambridge, Mass.: Harvard University Press, 1962.

Berutti, John Morris. "Italo-American Diplomatic Relations, 1922-28." Ph.D. dissertation, Stanford University, 1960.

Bischoff, Ralph F. Nazi Conquest Through German Culture. Harvard Political Studies Series. Cambridge, Mass.: Harvard University Press, 1942.

Blackford, Mansel G. The Bise of Modern Business in Great Britain. The United States, and Japan. Chapel Hill, N.C.: University of North Carolina Press, 1988.

Bondanella, Peter. The Eternal City: Roman Images in the Modern World. Chapel Hill, N.C.: Univ. of North Carolina Press, 1987.

Bracher, Rarl Dietrich. The German Dictatorship: The Origins, Structure, and Effects of National Socialism. Translated by Jean Steinberg. New York: Praeger, 1970.

Braun, Hans-Joachim. The German Economy in the Twentieth Century. London \& New York: Routledge, 1990.

Bretton, Henry L. Stresemann and the Revision of Versailles: A Eight for Reason. Stanford, Ca.: Stanford University Press, 1953.

Broszat, Martin. Hitler and the Collapse of Weimar Germany. Trans. V.R. Berghahn. Leamington Spa, UR: Berg, 1987. 
The Hitler State: The Eoundation and Development of the Internal Structure of the Third Beich. Trans. John W. Hiden. London and New York: Longman, 1981.

Browder, Robert Paul. The Origins of Soviet-American Diplomacy. Princeton, N.J.: Princeton University Press, 1953.

Buenker, John D., Burnham, John C., and Crunden, Robert M. Rrogressivism. Cambridge, Mass.: Schenkman Publishing Co., 1977.

Bullitt, Orville H., ed. Eor the Bresident: Bersonal and Secret: Correspondence Between Eranklin D. Roosevelt and Hilligm C. Bullitt. Boston: Houghton Mifflin Co., 1972 .

Bullock, Alan. Hitler, A Study in Tyranny. Completely revised edition. New York: Harper \& Row, 1962.

Hitler and Stalin: Parallel Lives.

New York: Alfred A. Knopf, 1992 .

Burleigh, Michael and Wippermann, Wolfgang. The Racial State: Germany 1933-1945. Cambridge: Cambridge University Press, 1991.

Burner, David. Herbert Hoover: A Bublic Life. New York: Alfred A. Knopf, 1979.

Burnham, James. The Managerial Revolution: What is Happening in the World. New York: The John Day Company, 1941.

Burns, Richard Dean. Guide to American Eoreign Relations Since 1700. Santa Barbara and Oxford: The Society for Historians of American Foreign Relations/ABC-Clio, 1983 .

Butler, Nicholas Murray. Looking Eorward: What Will The American Reople Do About It? Essays and Addresses on Matters National and International. New York, Charles Scribner's Sons, 1932.

Cannistraro, Philip V., ed. Historical Dictionary of Eascist Italy. Westport, Conn.: Greenwood Press, 1982 . 
Cannistraro, Philip V. and Sullivan, Brian R. Il Duce's Qther Woman: The Untold Story of Margherita Sarfatti. Benito Mussolini's Jewish Mistress, and How She Helped Him Come to Bower. New York: William Morrow \& Co., 1993.

Carr, Edward Hallett. German-Soviet Relations Between the Two World Wars, 1919-1939. Baltimore: Johns Hopkins Press, 1951.

Carr, William. A History of Germany 1815-1845. New York, St. Martin's Press, 1969 .

Carsten, F.L. The Rise of Eascism. Berkeley, Ca.: University of California Press, 1967.

Carter, John Booth. "American Reactions to Italian Fascism, 1919-1933." Ph.D. dissertation, Columbia University, 1953

Chandler, Alfred D., Jr. Strategy and Structure: Chapters in the History of the American Industrial Enterprise. Cambridge, Mass.: M.I.T. Press, 1962.

The Visible Hand: The Managerial

Revolution in American Business. Cambridge, Mass. \& London: Belknap Press of Harvard University Press, 1977 .

Chapman, John Jay, compiler. Deutschland Uber Alles or Germany Speaks. New York and London: G.P. Putnam's Sons, 1914.

Child, Maude Parker. The Social Side of Riplomatic Life. Indianapolis: Bobbs-Merrill Co., 1924.

Child, Richard Washburn. A Diplemat Leoks at Europe. New York: Duffield and Company, 1925.

Chomsky, Noam. Deterring Demecracy. London and New York: Verso, 1991.

Cohen, Warren I. Empire Hithout Tears: America's Eereign Relations, 1921-1933. New York: Alfred A. Rnopf, 1987.

Collier, Price. Germany and the Germans Erom an American Point of View. New York: Charles Scribner's Sons, 1913. 
Collin, Richard H. Theodore Roosevelt, Culture, Diplomacy, and Expansion: A New View of American Imperialism. Baton Rouge: Louisiana State University Press, 1985 .

Compton, James V. The Swastika and the Eagle: Hitler. The United States, and the Origins of World War II. Boston: Houghton Mifflin Company, 1967.

Conway, John, trans. The Path to Dictatorship: 1918-1933: Ten Essays by German Scholars. Garden City, N.J.: Doubleday, 1966.

Conwell, James Michael. "Opinion-Makers and Foreign Policy: The Concept of America's Role in World Affairs, the 1920s." Ph.D. dissertation, Michigan State University, 1977.

Cooper, John Milton, Jr. Rivotal Decades: The United States, 1900-1920. New York: W.W. Norton, 1990.

Coper, Rudolf. Eailure of a Revolution: Germany in 19181919. Cambridge: Cambridge Univ. Press, 1955.

Costigliola, Frank. Awkward Dominion: American Political, Economic, and Cultural Relations with Europe, 19191933. Ithaca, N.Y.: Cornell University Press, 1984.

Craig, Gordon A. Germany: 1866-1945. New York: Oxford University Press, 1978.

Craig, Gordon A., and Gilbert, Felix, editors. The Diplomats 1919-1939. Princeton, N.J.: Princeton University Press, 1953.

Croly, Herbert. The Bromise of American Life. [n.c.]: The Macmillan Company, 1909; reprint ed., [n.c.]: Archon Books, 1963.

Dallek, Robert. Eranklin D. Roosevelt and American Eoreign Belicy, 1932-1945. Oxford and New York: Oxford University Press, 1979. Paperback edition, Oxford Univ. Press, 1981.

Davis, Joseph S. The World Between The Wars, 1919-39: An Economist's Viek. Baltimore: Johns Hopkins University Press, 1975.

Davis, Renneth S. EDR: The New Deal Years 1933-1937, A History. New York: Random House, 1986. 
Dawes, Charles G. Journal as Ambassador to Great Britain. New York: Macmillan, 1939.

Deakin, F.W. The Brutal Eriendship: Mussolini, Hitler. and the Eall of Italian Eascism. New York: Harper \& Row, 1962 .

De Grazia, Victoria. How Eascism Ruled Women: Italy, 1922-1945. Berkeley: University of California Press, 1992 .

Delzell, Charles F. Mussolini's Enemies: The Italian Anti-Fascist Resistance. Princeton, N.J.: Princeton University Press, 1961.

De Santis, Hugh. The Diplomacy of Silence: The American Eoreign Service, the Soviet Union, and the Cold War. 1933-1947. Chicago: University of Chicago Press, 1980 .

Desmond, Robert W. Windows on the World: The Information Process In a Changing Society 1900-1920. Iowa City: University of Iowa Press, 1980.

Diggins, John P. Mussolini and Eascism: The View Erom America. Princeton: Princeton University Press, 1972 .

New York: W.W. Norton, 1992 .

Dodd, Martha. Through Embassy Eves. New York: Garden City Publishing Co., 1940.

Dodd, William E., Jr. \& Dodd, Martha, eds. Ambassador Dodd's Diary: 1933-1938. New York: Harcourt Brace \& Co., 1941.

Dressler, Thomas Herbert. "The Foreign Policies of American Individualism: Herbert Hoover, Reluctant Internationalist." Ph.D. dissertation, Brown University, 1973.

Ebenstein, William, and Fogelman, Edwin. Today's Isms: Communism. Eascism. Capitalism. Socialism. Eighth edition. Englewood Cliffs, New Jersey: Prentice-Hall, Inc., 1980.

Edwards, Julia. Women of the World: The Great Eoreign Correspondents. Boston, Houghton Mifflin, 1988. 
Einstein, Lewis. A Diplomat Leoks Back. Edited by Lawrence $E$. Gelfand. New Haven: Yale University Press, 1968.

Eyck, Erich. A History of the Heimar Republic. Translated by Harlan P. Hanson and Robert G.L. Waite. 2 vols. Cambridge, Mass.: Harvard University Press, 1963.

Feis, Herbert. The Diplomacy of the Dollar: Eirst Era. 1919-1932. Johns Hopkins Press, 1950. Reprint ed., Hamden, Conn.: Archon Books, 1965.

Little, Brown and Co., 1966.

Feat, Joachim C. The Eace of the Third Reich: Portraits of the Nazi Leadership. Trans. Michael Bulliock.

New York: Pantheon Books, 1870.

Fest, Joachim C. Hitler. Translated by Richard and Clara Winston. New York: Harcourt Brace Jovanovich, 1974; paperback ed., Vintage Books, 1975.

Filene, Peter G. Americans and the Soviet Experiment, 1917-1933. Cambridge, Mass.: Harvard University Press, 1967.

Finer, Herman. Mussolini's Italy. New York: Henry Holt and Company, 1935.

Fischer, Louis. Men and Rolitics: Europe Between The Two World Wars. New York: Duell, Sloan \& Pearce, 1941.

Fleming, D.F. The Cold War and Its Origins, 1917-1960. Volume One 1917-1950. Garden City, New York:

Doubleday \& Co., 1961.

Florinsky, Michael T. Eascism and National Socialism:

A Study of the Economic and Social Rolicies of the Totalitarian State. New York: The Macmillan Co., 1936 .

Friedrich, Carl J. and Brzezinski, Zbigniew $\mathrm{K}$. Totalitarian Dictatorship and Autocracy. 2nd ed., revised. Cambridge, Mass.: Harvard University Press, 1865 .

Friedrich, Otto. Before the Deluge: A Rortrait of Berlin in the $1920^{\prime} \mathrm{s}$. New York: Fromm International Publishing Corporation, 1986. 
Furnas, J.C. Stormy Weather: Crosslights on the Nineteen Thirties: An Informal Social History of the United States 1929-1941. New York: G.P. Putnam's Sons, 1977.

Gaddis, John Lewis. Russia, the Soviet Union, and the United States: An Interpretive History. New York, Alfred A. Knopf, 1978

Gardiner, A.G. Bertraits and Rortents. New York \& London: Harper \& Bros., 1926.

Gardner, Lloyd C. Safe for Democracy: The Anglo-American Response to Bevolution. 1913-1923. New York: Oxford University Press, 1984.

Gatzke, Hans. W. Germany and the United States: A "Special Relationship?" Cambridge, Mass.: Harvard University Press, 1980.

- Stresemann and the Rearmament of

Germany. Baltimore, Johns Hopkins Press, 1954.

Gay, H. Nelson. Strenuous Italy: Solving a Rerilous Broblem. Boston: Houghton Mifflin, 1927.

Gerberding, William P. United States Eoreign Policy: Rerspectives and Analysis. New York: McGraw-Hill, 1966 .

Glad, Betty. Charles Evans Hughes and the IIIusions of Innocence: A Study in American Diplomacy. Urbana, Illinois: University of Illinois Press, 1966.

Graebner, Norman A. An Uncertain Tradition: American Secretaries of State in the Twentieth Century. New York: MeGraw-Hill, 1961.

Grathwol, Robert P. Stresemann and the DNVP:

Reconciliation or Revenge in German Eoreign Rolicy 1924-1928. Lawrence, Ransas: The Regents Press of Ransas, 1980.

Gregor, A. James. Eascism: The Contemporary Interpretations. (University Programs Modular Studies). Morristown, N.J.: General Learning Press, 1973.

The Eascist Persuasion in Radical

Politics. Princeton, New Jersey: Princeton University Press, 1974. 
Halperin, S. William. Germany Tried Democracy: A Rolitical History of the Reich Erom 1918 to 1833. New York: Thomas Y. Crowell Company, 1946.

Hanfstaengl, Ernst. Unheard Witness. Philadelphia: J.B. Lippincott Company, 1957.

Hathaway, Robert M. Great Britain and the United States: Special Relations Since Werld War II. Twayne's International History Series. Boston: Twayne Publishers, 1990 .

Heald, Morrell. Transatlantic Vistas: American Journalists in Europe, 1900-1940. Kent, Ohio: Rent State University Press, 1988.

Herman, Edward S. Beyond Hypocrisy: Decoding the News in an Age of Bropaganda: Including a Doublespeak Dictionary for the $1990 \mathrm{~s}$. Illustrations by Matt Wuerker. Boston, South End Press, 1992.

Herrman, George Bernard. "American Journalistic Perceptions of the Death of Weimar Germany: January 1932-March 1933." D.A. dissertation, Carnegie-Mellon University, 1979.

Herzstein, Robert E. Roosevelt and Hitler: Rrelude to War. New York: Paragon House, 1989.

Hessen, Robert, ed. Berlin Alert: The Memoirs and Reports of Truman Smith. Stanford, California: Hoover Institution Press/Stanford University, 1984.

Hiden, John. Germany and Europe 1919-1939. London: Longman, 1977.

Hiden, John, and Farquharson, John. Explaining Hitler's Germany: Historians and the Third Reich. Totowa, New Jersey: Barnes \& Noble Books, 1983.

Hillgruber, Andreas. Germany and the Two World Wars. Trans. William C. Rirby. Cambridge, Mass.: Harvard University Press, 1981.

Hitchens, Christopher. Blood Class, and Nostalgia: Anele-American Ironies. New York: Farrar, Straus \& Giroux, 1990.

Hodgson, Godfrey. The Colonel: The Life and Wars of Henry Stimson, 1867-1950. New York: Alfred A. Rnopf, 1990. 
Hofstadter, Richard. The Age of Reform: Erom Bryan to E.D.R. New York: Alfred A. Knopf, 1961.

Anti-Intellectualism in American Life.

New York: Alfred A. Knopf, 1963.

Hogan, Michael J., and Paterson, Thomas G. Explaining th History of American Foreign Relations. Cambridge: Cambridge University Press, 1991.

Holborn, Hajo. A History of Modern Germany: 1840-1945.

Princeton, N.J. Princeton Univ. Press, 1969. ,ed. Republic to Reich: The Making of the Nazi Revolution: Ten Essays. Trans. Ralph Manheim. New York: Pantheon Books, 1972.

Hoover, Herbert. American Individualism. Garden City, New York: Doubleday, Page \& Co., 1923.

London: Charles Scribner's Sons, 1934.

The Memoirs of Herbert Hoover. Volume 1 , Years of Adventure, 1874-1920. New York: The Macmillan Co., 1951; Volume 2, The Cabinet and the Presidency, 1920-1933. New York: The Macmillan Co., 1952 .

Hughes, H. Stuart. The United States and Italy. Harvard University Press, 1953; Revised ed., New York: W.W. Norton \& Co., 1968.

Hull, Cordell. The Memoirs of Cordell Hull. 2 vols.: New York, Macmilian Co., 1948.

Jones, Renneth Paul, ed. U.S. Diplomats in Europe, 1919-1941. Santa Barbara: ABC-Clio, Inc. 1981. Reprint ed.: Santa Barbara, $\mathrm{ABC}-\mathrm{Cl}$ io, Inc., 1983.

Kennan, George F. American Diplomacy, 1900-1950. Chicago: University of Chicago Press, 1951.

\section{Brown \& Co., 1967.}

Rennedy, Paul. The Realities Behind Diplomacy: Background Influences on British External Policy, 1865-1980. London: George Allen \& Unwin, 1981. 
The Bise and Eall of the Great Powers:

Economic Change and Military Conflict from 1500 te 2000. New York: Random House, 1987.

Keynes, John Maynard. The Economic Consequences of the Peace. New York: Harcourt, Brace and Howe, 1920.

Kolb, Eberhard. The Weimar Republic. Trans. by P.S. Falla. London: Unwin Hyman, 1988.

Rosok, Paul. Modern Germany: A Study of Conflicting Lovalties (\#5, Studies in the Making of Citizens Series). Chicago: University of Chicago Press, 1933.

Rrock, Arthur. In The Nation: 1932-1966. New York: MoGraw-Hill Book Co., 1966.

Memoirs: Sixty Years on the Eiring Line. New York: Funk \& Wagnalls, 1968.

Rulski, Wladyslaw. Thus Speaks Germany. ed. W.W. Coole and M.F. Potter. New York: Harper \& Brothers, 1941. Reprint ed., New York: AMS Press, 1973.

Laqueur, Walter. Eascism: A Reader's Guide: Analyses, Interpretations, Bibliography. Berkeley: University of California Press, 1976.

- Russia and Germany. A Century of conflict. Boston: Little, Brown \& Co., 1985.

Lebovics, Herman. Social Conservatism and the Middle Classes in Germany, 1914-1933. Princeton, N.J.: Princeton Univ. Press, 1969.

Ledeen, Michael. The Eirst Duce: D'Annunzio at Eiume. Baltimore: Johns Hopkins University Press, 1977.

Universal Eascism: The Theory and

Practice of the Eascist International. 1928-1936.

New York: Howard Fertig, 1972.

Lee, Stephen J. The European Dictatorships 1918-1945. London and New York: Methuen, 1987.

Leffler, Melvyn P. The Elusive Quest: America's Pursuit of European Stability and Erench Security. 1919-1933. Chapel Hill, N.C.: Univ. of North Carolina Press, 1979 . 
Levin, N. Gordon, Jr. Woodrow Wilson and World Polities: America's Response to War and Revolution. New York: Oxford University Press, 1968.

Libbey, James K. American-Russian Economic Relations, $1770^{\circ}$ 's-1990's: A Survey of Issues and Literature. Claremont, Ca.: Regina Books, 1989.

Lippmann, Walter. Interpretations, 1931-1932. Selected and edited by Allan Nevins. New York: The Macmillan Company, 1932 .

\section{Macmillan Co., 1929.}

A Preface te Morals. New York: The

Lisagor, Nancy, \& Lipsius, Frank. A Law Unte Itself: The Untold Story of the Law Eirm Sulitivan \& Cromwell. New York: William Morrow \& Co., 1988.

Ludecke, Kurt G.W. I Rnew Hitler: The Story of a Nazi who Escaped The Blood Burge. New York: Charles Scribner's Sons, 1938.

Ludwig, Emil. Talks With Mussolini. Trans. Eden and Cedar Paul. Boston: Little, Brown \& Co., 1933.

Lyttelton, Adrian. The Seizure of Power: Fascism in Italy, 1919-1929. Second ed. Princeton, N.J.: Princeton University Press, 1987.

Mack Smith, Denis. Italy, A Modern History. Revised and enlarged edition. Ann Arbor: University of Michigan Press, 1969.

1982 .

Mussolini. New York: Alfred A. Knopf, Mussolini's Roman Empire. New York: The Viking Press, 1976.

May, Ernest R. "Lessons" of the Past: The Use and Misuse of History in American Eoreign Policy. New York:

Oxford University Press, 1973. Paperback ed., Oxford University Press, 1975.

Mayer, Arno J. Rolitics and Diplomacy of Peacemaking: Containment and Counterrevolution at Versailles, 19181919. New York: Alfred A. Knopf, 1967. 
Mayers, David. George Kennan and the Dilemmas of US Eoreign Roliey. New York: Oxford University Press, 1988 .

MeElvaine, Robert $S$. The Great Depression: America. 1929-1941. [n.c.]: Times Books, 1984.

McKercher, B.J.C. Anglo-American Relations in the 1920s: The Struggle for Supremacy. Edmonton; Univeristy of Alberta Press, 1990.
Cambridge: Cambridge University Press, 1989.

United States. 1924-192

Medlicott, W.N. British Foreign Policy Since Versailles, 1919-1963. Second revised edition. London: Methuen $\&$ Co., 1968.

Moffat, Jay Pierrepont. The Moffat Papers: Selections Erom The Diplomatic Journals of Jay Rierrepont Moffat. 1919-1943, edited by Nancy Harvison Hooker.

Cambridge: Harvard University Press, 1956.

Morgan, J.H. Assize of Arms: The Disarmament of Germany and Her Rearmament (1919-1939). New York: Oxford University Press, 1946.

Morgenthau, Henry, III. Mostly Morgenthaus: A Eamily History. New York: Ticknor \& Fields, 1991.

Mosse, George, ed. Nazi Culture: Intellectual, Cultural and Social Life in the Third Reich. Translations by Salvator Attanasio and others. New York: Grosset and Dunlap, 1966.

Mowrer, Edgar Ansel. Germany Puts the Clock Back. New York: William Morrow \& Co., 1933; rev. ed., 1939. \& Company, 1922 .

Immortal Italy. New York: D. Appleton Sears \& Co., 1928.

Mowrer, Lilian T. Journalist's Wife. New York: William Morrow \& Company, 1937. 
Murray, Robert R. Red Scare: A Study of National

Hysteria, 1919-1920. New York: McGraw-

Hill/University of Minnesota Press, 1955.

Murphy, Robert. Diplomat Among Warriors. Garden City, N.Y.: Doubleday and Co., 1964.

Mussolini, Benito. Eascism: Doctrine and Institutions. Rome: Ardita, 1935; reprint ed., New York: Howard Fertig, 1968.

Scribner's Sons, 1928.

Nevins, Allan and Hacker, Louis M., eds. The United States and Its Place in World Affairs, 1918-1943. Boston: D.C. Heath \& Co., 1943.

Nicholls, Anthony and Matthias, Erich, eds. German Democracy and the Triumph of Hitler: Essays in Recent German History. London: George Allen and Unwin Ltd., 1971 .

Nolte, Ernst. Three Eaces of Eascism: Action Erancaise, Italian Eascism, National Socialism. Translated by Leila Vennewitz. New York: Holt, Rinehart and Winston, 1966 .

Offner, Arnold A. American Appeasement: United States Eoreign Policy and Germany, 1933-1938. Cambridge Mass.: Harvard University Press, 1969; New York: W.W. Norton, 1976.

The Origins of the Second World War: American Foreign Policy and World Rolitics, 1917-1941. New York: Praeger Publishers, 1975.

Orlow, Dietrich. The History of the Nazi Party: 1919-1933. 2 vols. Pittsburgh: University of Pittsburgh Press, 1969 .

Pachter, Henry. Weimar Etudes. New York: Columbia University Press, 1982.

Parrini, Carl. Heir to Empire: United States Economic Diplomacy, 1916-1923. Pittsburgh: Univ. of Pittsburgh Press, 1969. 
Payne, Howard C., Callahan, Raymond, and Bennett, Edward M. As the Storm Clouds Gathered: European Perceptions of American Eoreign Policy in the 1930s. Durham, N.C.: Moore Publishing Co., 1979.

Payne, Stanley G. Eascism: Comparison and Definition. Madison, Wisconsin: University of Wisconsin Press, 1980 .

Peukert, Detlev J.K. The Heimar Republic: The Crisis of Classical Modernity. Trans.: Richard Deveson. New York: Hill and Wang, 1992.

Pool, James, and Pool, Suzanne. Whe Einanced Hitler: The Secret Funding of Hitler's Rise to Rower 1919-1933. New York: The Dial Press, 1978.

Propas, Frederic Lewis. "The State Department, Bureaucratic Politics and Soviet-American Relations, 1918-1938." Ph.D. dissertation, UCLA, 1982.

Prothro, James Warren. The Dollar Decade: Business Ideas in the 1920s. Baton Rouge: Louisiana State University Press, 1954.

Quigley, Hugh, and Clark, R.T. Republican Germany: A Bolitical and Economic Study. London: Methuen \& Co., 1928; reprint ed., New York: Howard Fertig, 1968.

Renouvin, Pierre. World War II and Its Origins: International Relations, 1929-1945. Trans. Remy Inglis Hall. New York: Harper \& Row, 1969.

Reynolds, P.A. British Eoreign Policy in the Inter-War Years. London: Longmans, Green \& Co., 1954.

Robertson, Esmonde M. Mussolini as Empire-Builder: Europe and Africa, 1932-36. The Making of the 20th Century Series. New York: St. Martin's Press, 1977.

Rosenberg, Arthur. A History of the German Republic. Trans. by Ian F.D. Morrow and L. Marie Sieveking. London: Methuen \& Co., 1936. Reissue, New York: Russell \& Russell, 1965.

Rosenberg, Emily S. Spreading the American Dream: American Economic and Cultural Expansion, 1890-1945. New York: Hill and Wang, 1982. 
Rubin, Barry. Secrets of State: The State Department and the Struggle over U.S. Eoreign Rolicy. New York: Oxford University Press, 1985.

Ryder, A.J. The German Revolution of 1918: A Study of German Socialism in War and Revolt. Cambridge: Cambridge University Press, 1967.

Salvemini, Gaetano. The Eascist Dictatorship in Italy. New York: Holt, Rinehart \& Winston, 1927. Reprint ed., New York: Howard Fertig, 1967.

Under the Axe of Eascism. [New York: 1936]. Reprint ed., New York: Howard Fertig, 1969.

Schlesinger, Arthur M., Jr. The Crisis of the Old Order, 1919-1933. Boston: Houghton Mifflin Co., 1957.

Schmidt, Carl T. The Corporate State in Action: Italy Under Eascism. New York: Oxford University Press, 1939 .

Schneider, Herbert $W$, and Clough, Shepard B. Making Eascists. Studies in the Making of Citizens Series. Chicago: Univ. of Chicago Press, 1929.

Schoenbaum, David. Hitler's Social Revolution: Class and Status in Nazi Germany 1933-1939. [n.c.]: Doubleday \& Co., 1966. Reprint ed., New York and London: W.W. Norton \& Co., 1980.

Schoenthal, Klaus Ferdinand. "American Attitudes Toward Germany, 1918-1932." Ph.D dissertation, Ohio State University, 1959.

Schulzinger, Robert D. American Diplomacy in the Twentieth Century. New York: Oxford Univ. Press, 1984.

The Making of the Diplomatic Mind: The Training, Qutlook, and Style of United States Eoreign Service officers, 1908-1931. Middleown, Conn.: Wesleyan University Press, 1975.

"The Making of the Diplomatic Mind: The Training, Outlook, and Style of United States Foreign Service Officers, 1906-1928." Ph.D. Dissertation: Yale University, 1971.

Schwartz, Thomas Alan. America's Germany: John J MeCloy and the Eederal Republic of Germany. Cambridge, Mass.: Harvard University Press, 1991. 
Schwarz, Jordan A. The Interregnum of Despair: Hoover, Congress, and the Depression. Urbana, I11.:

University of IIIinois Press, 1970.

Seldes, George. You Can't Print That! The Truth Behind the News, 1918-1928. New York: Payson \& Clarke, Ltd., 1929 .

Seton-Watson, Hugh. Nationalism and Communism: Essays 1946-1963. New York: Frederick A. Praeger, 1964.

Seton-Watson, R.W. Britain and the Dictators: A Survey of Post-War British Policy. New York: MacMillan; Cambridge: Cambridge Univ. Press, 1938.

Shirer, William L. Berlin Diary: The Journal of a Eoreign Correspondent, 1934-1941. New York: Alfred A. Knopf, 1941 .

Smith, Richard Norton. An Uncommon Man. The Triumph of Herbert Hoover. New York: Simon and Schuster, 1984.

Spaulding, E. Wilder. Ambassadors Ordinary and Extraordinary. Washington, D.C.: Public Affairs Press, 1961.

Speer, Albert. Inside the Third Reich: Memoirs by Albert Speer. Translated by Richard and Clara Winston. New York: The Macmillan Co., 1970.

Stern, Fritz. Dreams and Delusions: The Drama of German History. New York: Alfred A. Knopf, 1987.

The Eailure of Illiberalism: Essays on the Political Culture of Modern Germany. New York: Alfred A. Knopf, 1972.

in the Rise of the German Ideology. Berkeley:

A Study University of California Press, 1961.

Stimson, Henry L., and Bundy, McGeorge. On Active Service in Peace and War. New York: Harper \& Brothers, 1948.

Tasca, Angelo [A. Rossi]. The Rise of Italian Eascism. 1918-1922. Trans. Peter and Dorothy Watt. New York: Howard Fertig, 1966. 
Taylor, A.J.P. The Origins of the Second World War. With a preface for the American reader and a new introduction, Second thoughts. New York: Atheneum, 1983.

Thompson, John M. Bussia, Bolshevism, and the Versailles Peace. Princeton: Princeton University Press, 1966.

Turner, Henry Ashby, Jr. German Big Business and the Rise of Hitler. New York: Oxford University Press, 1985. , ed. Hitler-Memoirs of a Confidant. Trans. Ruth Hein. New Haven: Yale University Press, 1978 .

Stresemann and the Politics of the Weimar Republic. Princeton, N.J.: Princeton University Press, 1963.

Vance, William L. America's Rome: Volume II, Catholic and Contemporary Rome. New Haven: Yale University Press, 1989 .

Vansittart, Lord. Lessons of My Life. New York: Alfred A. Knopf, 1943.

Varg, Paul A. America. Erom Client State to World Power: Six Major Transitions in United States Eoreien Relations. Norman, Oklahoma: University of Oklahoma Press, 1990.

Villard, Oswald Garrison. The German Phoenix: The Story of the Republic. New York: Harrison Smith \& Robert Haas, 1933.

\section{London: Alfred A. Knopf, [1928].}

Watt, Donald Cameron. How Har Came: The Immediate Origins of the Second World War, 1938-1939. New York:

Pantheon Books, 1989.

Personalities and Rolicies: Studies in the Formulation of British Foreign Bolicy in the Twentieth Century. South Bend, Ind.: Univ. of Notre Dame Press, 1965; reprint ed., Westport, Conn.: Greenwood Press, 1975.

Weber, Eugen. Varieties of Eascism: Doctrines of Revolution in the Twentieth Century. New York: Van Nostrand Reinhold Company, 1964. 
Weil, Martin. A Rretty Good Club: The Eounding Eathers of the U.S. Eoreign Service New York: W.W. Norton \& Co., 1978 .

Wite, Stephen. Britain and the Bolshevik Revolution: A Study in the Politics of Diplomacy, 1920-1924.

London: Macmillan, 1979.

Wiebe, Robert H. Businessmen and Reform: A Study of the Rrogressive Movement. Cambridge, Mass.: Harvard University Press, 1962.

The Search For Order: 1877-1920.

[The Making of America Series, Vol. 5]. New York: Hill and Wang, 1967.

Wilbur, Ray Lyman, and Hyde, Arthur Mastick. The Hoover Policies. New York: Charles Scribner's Sons, 1937.

Williams, William Appleman. The Tragedy of American Diplomacy. Second Revised and Enlarged Edition. New York: Dell Publishing Co., 1972.

Wilson, Joan Hoff. American Business and Eoreign Bolicy, 1920-1933. Lexington, Rentucky: The University Press of Rentucky, 1971.

With the Soviet Union. 1918-1933. Columbia, Mo.: University of Missouri Press, 1974.

Wilson, Lawrence, trans. The Road to Dictatorship: Germany 1918-1933. London: Oswald Wolff, 1964.

Woodard, Nelson Eugene. "Postwar Reconstruction and International Order: A Study of the Diplomacy of Charles Evans Hughes, 1921-1925." Ph.D. dissertation, University of Wisconsin, 1970.

Wynn, Neil A. Erom Brogressivism to Prosperity: World War I and American Society. New York/London: Holmes \& Meier, 1986.

Yergin, Daniel. Shattered Reace: The Origins of the Cold War and the National Security State. Boston: Houghton Mifflin Co., 1977. 